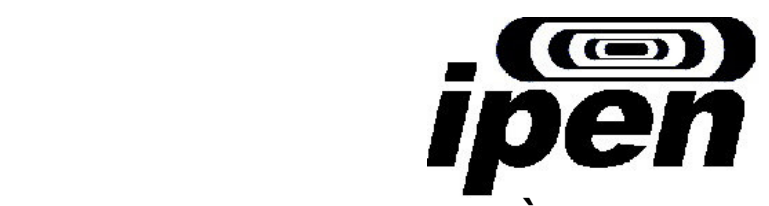

AUTARQUIA ASSOCIADA À UNIVERSIDADE DE SÃO PAULO

\title{
AVALIAÇÃO DO DESEMPENHO DE EMBALAGENS PARA ALIMENTOS QUANDO SUBMETIDAS A TRATAMENTO POR RADIAÇÃO IONIZANTE
}

\section{ESPERIDIANA AUGUSTA BARRETOS DE MOURA}

Tese apresentada como parte dos requisitos para a obtenção do Grau de Doutor em Ciências na Área de Tecnologia Nuclear - Aplicação.

Orientador:

Dr. Leonardo Gondim de Andrade e Silva 
Com enorme gratidão e carinho à minha familia. meus pais Emanuel "in memoriam" e Maria da Glória e irmãos Clemanceau, Emanuel, Izabel e Taciana. 


\section{AGRADECIMENTOS}

Ao Dr. Leonardo Gondim de Andrade e Silva que se dispôs a me orientar, obrigada pela confiança, pela discussão dos resultados e revisão dos manuscritos.

Ao MSc. Angel Visentim Ortiz pelo apoio e colaboração na obtenção dos materiais de embalagens, auxílio técnico, discussão dos resultados e sobretudo amizade, merecedor de profundo apreço e gratidão, o meu muito obrigada.

Ao Prof. Dr. Hélio Wiebeck pelo total apoio e incentivo, pela orientação, ensinamentos, direcionamento, compreensão, e sobretudo paciência e amizade.

Ao Dr. Wilson Aparecido Calvo Chefe do Centro de Tecnologia das Radiações CTR/IPEN-CNEN/SP, pelo apoio e compreensão recebidos e pela oportunidade de realização deste trabalho.

Ao Instituto de Pesquisas Energéticas e Nucleares - IPEN-CNEN/SP pela oportunidade de realização deste trabalho.

À Unipac Embalagens Ltda., pelo apoio, fornecimento dos materiais de embalagens e suporte técnico, durante todo o desenvolvimento deste trabalho.

Ao Engo Geraldo Antonio Cofcewicz da Perdigão Agroindustrial S/A pelo apoio e suporte técnico para o desenvolvimento deste trabalho.

À Química Ana Beatriz de Almeida Paula, pela dedicação, colaboração na preparação das amostras, irradiação e na obtenção dos resultados dos ensaios durante o desenvolvimento deste trabalho.

Ao aluno Alexandre de Oliveira Camargo, pela dedicação, colaboração na preparação das amostras, irradiação e na obtenção dos resultados dos ensaios durante o desenvolvimento deste trabalho.

À Enga Renata Naomi Morita do Laboratório da Garantia da Qualidade da Unipac Embalagens Ltda. pela colaboração nas análises de produtos voláteis.

Ao Químico Jorge Lopes da Costa do Laboratório da Garantia da Qualidade da Unipac Embalagens Ltda. pela colaboração nas análises de permeabilidade.

Ao aluno Paulo Henrique Diogo Gouvêa, pela dedicação, colaboração na preparação das amostras, irradiação, na obtenção dos resultados dos ensaios ensaios mecânicos e de espectroscopia UV/VIS. 
À Enga Alessandra Naves Teixeira pela dedicação e colaboração na preparação das amostras, irradiação e na obtenção dos resultados dos ensaios de espectroscopia UV/VIS e ensaios mecânicos do filme de polietileno de baixa densidade.

Ao Engo Carlos Gaia da Silveira, pelo apoio e colaboração na irradiação das amostras.

Á Engo Elizabeth Sebastiana Somessari, pelo apoio e colaboração na irradiação das amostras.

À MSc. Celia Marina Napolitano, pelo levantamento das curvas dosimétricas dos irradiadores de elétrons e de ${ }^{60} \mathrm{Co}$ e colaboração nos ensaios de espectroscopia UV/VIS.

Ao aluno Danilo Cardenuto Ferreira, pela colaboração nos ensaios de espectroscopia UV/VIS.

Ao Técnico Sebastião Feliciano da Silva, pela colaboração nos ensaios de espectroscopia UV/VIS.

Ao Químico Djalma Batista Dias pela colaboração nos ensaios mecânicos.

Ao MSc. Gilberto Carvalho, por sua valiosa colaboração e sugestões, sobretudo pelo apoio, amizade e incentivo.

À MSc. Maria da Conceição Costa Pereira, por sua valiosa colaboração, sobretudo pelo apoio, amizade e incentivo.

À Cláudia Regina Nolla sempre disposta a cooperar, pelo espírito de cooperação e apoio durante a realização deste trabalho.

Ao Marcos Cardoso da Silva pelo apoio e cooperação durante a realização deste trabalho. 


\section{AVALIAÇÃO DO DESEMPENHO DE EMBALAGENS PARA ALIMENTOS QUANDO SUBMETIDAS A TRATAMENTO POR RADIAÇÃO IONIZANTE}

\section{ESPERIDIANA AUGUSTA BARRETOS DE MOURA}

\section{RESUMO}

No presente trabalho foram estudadas as propriedades mecâncias (resistência à tração e porcentagem de alongamento na ruptura e resistência à perfuração), propriedades ópticas, permeabilidade ao gás oxigênio e ao vapor d'água, migração total em simulante aquoso (ácido acético 3\%) e gorduroso (nheptano), e a formação de produtos voláteis da radiólise, com vistas à avaliar o efeito da radiação ionizante (raios gama e feixe de elétrons) em filmes flexíveis mono e multicamadas comerciais, fabricados no Brasil para a indústria de produtos cárneos. Os filmes estudados foram: um monocamada de polietileno de baixa densidade (LDPE) e um multicamadas coextrusado composto de polietileno de baixa densidade (LDPE), copolímero de etileno e álcool vinílico (EVOH) e poliamida (PA), ou seja, a estrutura: LDPE/EVOH/PA. As irradiações foram realizadas em uma fonte de ${ }^{60} \mathrm{Co}$ do tipo Gammacell e em um acelerador de elétrons do tipo eletrostático $(1,5 \mathrm{MeV})$, com doses de até $30 \mathrm{kGy}$, na temperatura ambiente e presença de ar. As alterações nas propriedades foram avaliadas de acordo com a dose de radiação aplicada, oito dias após a irradiação e novamente, dois a três meses após a irradiação. Os resultados mostraram que as reações de cisão predominaram sobre as reações de reticulação para ambos os filmes estudados, irradiados com raios gama ou com feixe de elétrons. As variações observadas em função da irradiação, nas propriedades avaliadas não limitam a aplicação final desses filmes, uma vez que não ultrapassaram o limite de segurança especificado pelo fabricante em nenhuma dose e período em que foram estudadas. Concluiu-se que os filmes estudados podem ser utilizados, sob o ponto de vista das propriedades avaliadas, como embalagens para produtos pasteurizáveis por radiação e radioesterilizáveis usando irradiadores gama ou aceleradores de elétrons, nas doses de radiação estudadas. 


\title{
EVALUATION OF PERFORMANCE OF FOOD PACKAGINGS WHEN TREATED WITH IONIZING RADIATION
}

\author{
ESPERIDIANA AUGUSTA BARRETOS DE MOURA
}

\begin{abstract}
In this study the mechanical properties (tensile strength and percentage elongation at break and penetration resistance), optical properties, gas oxygen and water vapor permeability, the overall migration tests into aqueous food simulats ( $3 \%$ aqueous acetic acid) and fatty food simulat (n-heptane), as well as the formation of volatile radiation products tests were used to evaluate the effects of ionizing radiation (gamma irradiation or electron-beam irradiation) on commercial monolayer and multilayer flexible plastics packaging materials. These films are two typical materials produced in Brazil for industrial meat packaging, one of them is a monolayer low-density polyethylene (LDPE) and other is a multilayer coextruded low-density polyethylene (LDPE), ethylene vinyl alcohol $(\mathrm{EVOH})$, polyamide (PA) based film (LDPE/EVOH/PA). Film samples were irradiated with doses up to $30 \mathrm{kGy}$, at room temperature and in the presence of air with gamma rays using a ${ }^{60} \mathrm{Co}$ facility and electron beam from $1.5 \mathrm{MeV}$ electrostatic accelerator. Alterations of these properties were detected according to the dose applied initially eight day after irradiation took place and new alterations of these values when the properties were evaluate two to three months after irradiation process. The results showed that scission reactions are higher than cross-linking process for both studied films, irradiated with gamma rays and electron beam. The evaluated properties of the irradiated films were not affected significantly with the dose range and period studied. The monolayer Unipac PE-60 and the multilayer Lovaflex $\mathrm{CH} 130$ films can be used as food packaging materials for food pasteurization and in the sterilization process of by ionizing radiation using a gamma facilities and electron beam accelerators in commercial scale.
\end{abstract}




\section{SUMÁRIO}

Página

LISTA DE TABELAS...........................................................................

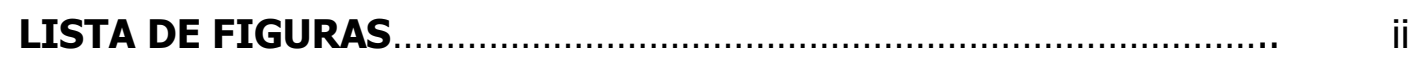

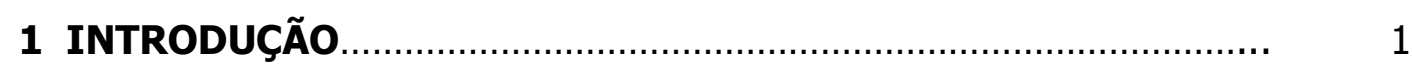

2 OBJETIVOS E ASPECTOS RELEVANTES........................................ 4

2.1 Objetivo do trabalho............................................................................. 4

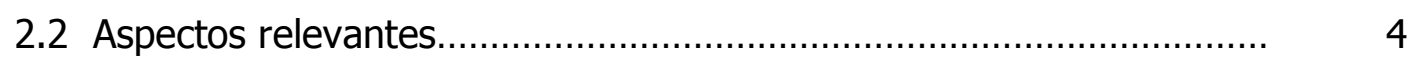

3 CONTRIBUIÇÃO E ORIGINALIDADE DO TRABALHO....................... 6

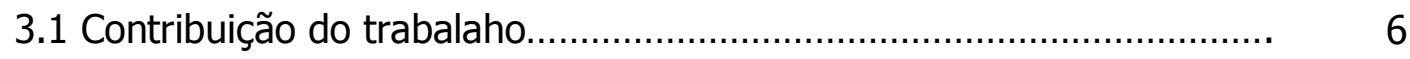

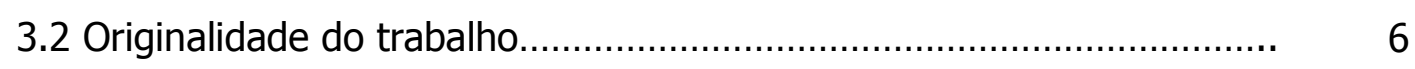

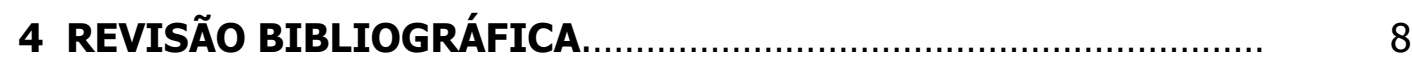

4.1 Embalagens para produtos cárneos ................................................ 8

4.1.1 Polímeros e embalagens plásticas flexíveis...................................... 10

4.1.1.1 Conceito de polímero.............................................................. 10

4.1.1.2 Outros conceitos...................................................................... 11

4.1.1.3 Polímeros usados como materiais de embalagem......................... 16

4.1.1.3.1 Polietileno - "PE" ....................................................................... 16

4.1.1.3.2 Polipropileno - "PP" .................................................................. 19

4.1.1.3.3 Poliamida - "PA" ............................................................... 20

4.1.1.3.4 Copolímero de etileno e acetato de vinila - "EVA" .................... 23

4.1.1.3.5 Copolímero de etileno e álcool vinílico - "EVOH" ...................... 25

4.1.1.4 Embalagens plásticas flexíveis .................................................. $\quad 26$

4.1.1.5 Propriedades das embalagens plásticas flexíveis .......................... 29

4.1.1.5.1 Interação produto - embalagem.............................................. 34

4.2 Radiação ionizante.................................................................. $\quad 35$

4.2.1 Efeito fotoelétrico....................................................................

4.2.2 Efeito Compton ......................................................................

4.2.3 Produção de pares............................................................................ 40 
4.2.4 Radiação ionizante de interesse para a química de polímeros.......... 41

4.2.4.1 Raios gama....................................................................... 41

4.2.2.2 Feixe de elétrons...................................................................... 42

4.2.5 Irradiadores gama e aceleradores de elétrons ............................... 43

4.2.5.1 Irradiadores gama.................................................................. 43

4.2.5.2 Aceleradores de elétrons ....................................................... 48

4.3 A radiação ionizante e a preservação de alimentos......................... 52

4.4 A radiação ionizante e os materiais de embalagens ...................... 55

4.4.1 Efeitos da radiação ionizante sobre os materiais poliméricos........ 56

5 MATERIAIS E MÉTODOS …....................................................... 65

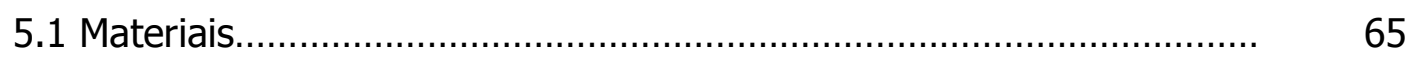

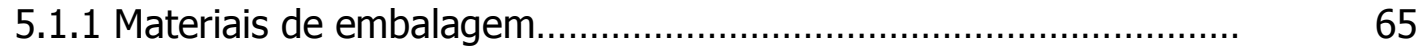

5.2 Métodos.................................................................................. 67

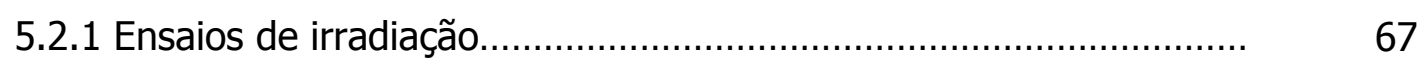

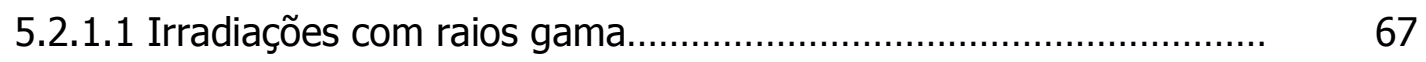

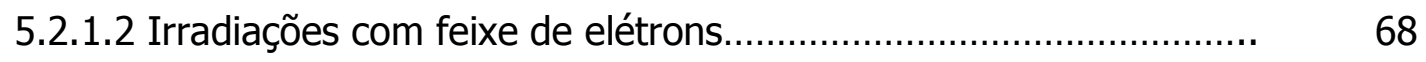

5.2.2 Análises............................................................................. 69

5.2.2.1 Ensaios mecânicos................................................................

5.2.2.1.1 Ensaios mecânicos de tração.................................................. $\quad 70$

5.2.2.1.2 Ensaios mecânicos de resistência à perfuração........................... 71

5.2.2.2 Análises de UV/VIS.................................................................. 71

5.2.2.3 Ensaios de permeabilidade...................................................... 72

5.2.2.3.1 Permeabilidade ao vapor d'água .............................................. 73

5.2.2.3.2 Permeabilidade ao gás oxigênio.................................................. 73

5.2.2.4 Ensaios de migração total em simulantes para alimentos............. $\quad 74$

5.2.2.5 Análises de produtos voláteis ................................................... 74

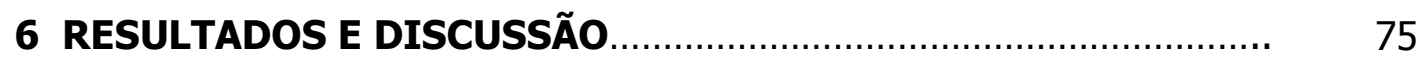

6.1 Aspectos visual e sensorial dos filmes após a irradiação................... 75

6.1.1 Filme Unipac-PE-60 …....................................................... 75

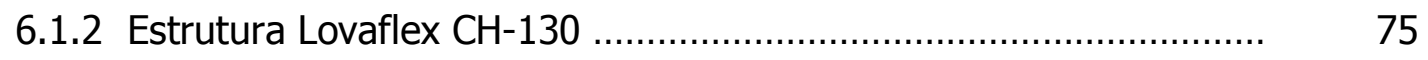

6.2 Ensaios mecânicos ...............................................................

6.2.1 Ensaios mecânicos de tração.......................................................... 
6.2.1.1 Resistência à tração no ponto de ruptura...................................... 75

6.2.1.2 Porcentagem de alongamento na ruptura..................................... 82

6.2.2 Ensaios mecânicos de resistência à perfuração............................... 90

6.3 Análises de UV/Vis....................................................................... 93

6.4 Permeabilidade ao vapor d'água....................................................... 103

6.5 Permeabilidade ao gás oxigênio.................................................... 110

6.6 Ensaios de migração total em simulantes para alimentos.................. 113

6.6.1 Migração total em n-heptano e em ácido acétio a 3\% para o filme Unipac-PE-60

6.6.2 Migração total em n-heptano e em ácido acétio a 3\% para a Estrutura Lovaflex $\mathrm{CH} 130$

6.7 Análises de produtos voláteis ............................................................ 119

7 CONCLUSÕES .......................................................................... 120

8 SUGESTÕES PARA TRABALHOS FUTUROS..................................... 125

8.1 Avaliação das propriedades dos filmes estudados............................... 125

8.1.1 Ensaios mecânicos................................................................... 125

8.1.2 Análises de migração total......................................................... 126

8.1.3 Análise de produtos voláteis …............................................... 126

8.1.4 Massa molar média viscosimétrica e densidade de ligações cruzadas.

8.1.5 Avaliar a evolução das propriedades estudadas ao longo do tempo 127

8.1.6 Avaliar a influência da temperatura de irradiação no desempenho dos filmes estudados

8.2 Avaliar o desempenho das propriedades da estrutura coextrusada Lovaflex LM 110 após tratamento por radiação ionizante 


\section{LISTA DE TABELAS}

Tabela

Título

1 Energia e distância de ligação de algumas ligações primárias comuns em sistemas poliméricos

2 Principais características dos filmes Unipac PE 60 e Lovaflex $\mathrm{CH} 130$

3 Absorção máxima dos principais grupos cromóforos de produtos de oxidação
Página

61

66

102 


\section{LISTA DE FIGURAS}

Figura

Título

1 Representação da estrutura do polietileno

17

2 Representação da estrutura do polipropileno....................... 20

3 Representação estrutural de uma poliamida....................... 21

$4 \quad$ Representação da estrutura da poliamida 6 (PA 6).............. 22

5 Representação da estrutura da poliamida 6.6 (PA 6.6).......

23

6 Representação da estrutura da copoliamida 6, 6.6 (PA 6, 6.6).

23

7 Representação da estrutura do copolímero de etileno e acetato de vinila - EVA.

8 Representação da estrutura do copolímero de etileno e álcool vinílico - EVOH.

9 Representação do efeito fotoelétrico

10 Representação do efeito Compton

39

11 Representação da produção de pares..................................

12 Penetração do feixe de elétrons em função da energia em $\mathrm{MeV}$.

13 Irradiador gama de cobalto-60 tipo Gammacell, categoria I pela AIEA.

14 Irradiador gama de cobalto-60 tipo panorâmico, categoria II pela AIEA.

15 Irradiador gama de cobalto-60, categoria III pela AIEA.....

16 Irradiador gama de cobalto-60, categoria IV pela AIEA.......

17 Ilustração do princípio de funcionamento de um acelerador de elétrons pelo processo direto. 
Figura

Título

Página

18 Bobina do filme monocamada Unipac PE 60..................... 65

19 Imagem (corte transversal) da estrutura Lovaflex $\mathrm{CH} 130$ obtida com o aumento de 1000 vezes, utilizando o microscópio Leica tipo DM LM/P.

20 Irradiador gama de cobalto-60 tipo Gammacell 220............ 68

$21 \quad$ Acelerador de elétrons modelo Dynamitron II..................... 69

22 Dinamômetro da marca INSTRON, modelo 5567................. 70

23 Dinamômetro da marca INSTRON, modelo 5567 e acessórios construídos de acordo com a ASTM F 1306-90, para os esnsaios de resistência à perfuração.

24 Espectrofotômetro Shimadzu modelo UV1601PC................. 72

25 Equipamento Permatran-W Twin, modelo MOCON PN 140053

26 Resistência à tração no ponto de ruptura em função da dose de radiação para o filme Unipac-PE-60, oito dias após a irradiação com raios gama ou com feixe de elétrons.

27 Resistência à tração no ponto de ruptura em função da dose de radiação para o filme Unipac-PE-60, 2 meses após a irradiação com raios gama ou com feixe de elétrons.

28 Comparação entre os valores da resistência à tração do filme Unipac-PE-60, não irradiado, oito dias e dois meses após a irradiação com raios gama ou com feixe de elétrons e o seu valor limite de segurança.

29 Resistência à tração no ponto de ruptura em função da dose de radiação para a estrutura Lovaflex $\mathrm{CH}$ 130, oito dias após a irradiação com raios gama ou com feixe de elétrons.

30 Resistência à tração no ponto de ruptura em função da dose de radiação para a estrutura Lovaflex $\mathrm{CH}$ 130, 2 meses após a irradiação com raios gama ou com feixe de elétrons. 
Figura

Título

Página

31 Comparação entre os valores da resistência à tração da estrutura Lovaflex $\mathrm{CH}$ 130, não irradiada, oito dias e dois meses após a irradiação com raios gama ou com feixe de elétrons e o seu valor limite de segurança.

32 Porcentagem de deformação em função da dose de radiação para o filme Unipac-PE-60 oito dias após a irradiação com raios gama ou com feixe de elétrons.

33 Porcentagem de deformação em função da dose de radiação para o filme Unipac-PE-60 dois meses após a irradiação com raios gama ou com feixe de elétrons.

34 Variação da porcentagem de deformação original do filme Unipac-PE-60, em função da dose de radiação, oito dias e dois meses após a irradiação com raios gama ou com feixe de elétrons.

35 Porcentagem de alongamento no ponto de ruptura em função da dose de radiação para a estrutura Lovaflex $\mathrm{CH}$ 130 oito dias após a irradiação com raios gama ou com feixe de elétrons.

36 Porcentagem de deformação em função da dose de radiação para a estrutura Lovaflex $\mathrm{CH} 130$ dois meses após a irradiação com raios gama ou com feixe de elétrons.

37 Variação da porcentagem de deformação original para a estrutura Lovaflex $\mathrm{CH} 130$ irradiada em função da dose de radiação, oito dias e dois meses após a irradiação com raios gama ou com feixe de elétrons

38 Resistência à pefuração para o filme Unipac-PE-60 em função da dose de radiação com raios gama ou com feixe de elétrons.

39 Resistência à pefuração para a estrutura Lovaflex $\mathrm{CH} 130$ em função da dose de radiação com raios gama ou com feixe de elétrons.

40 Espectros de absorbância para o filme Unipac-PE-60 oito dias após irradiação com raios gama, no intervalo de dose de radiação entre 0 - 30 kGy. 
41 Espectros de absorbância para o filme Unipac-PE-60 oito dias após irradiação com feixe de elétrons, no intervalo de dose de radiação entre 0 - 30 kGy

42 Espectros de absorbância para a estrutura Lovaflex $\mathrm{CH}$ 130 oito dias após irradiação com raios gama, no intervalo de dose de radiação entre 0 - 30 kGy.

43 Espectros de absorbância para a estrutura Lovaflex $\mathrm{CH}$ 130 oito dias após irradiação com feixe de elétrons, no intervalo de dose de radiação entre 0 - 30 kGy

44 Espectros de porcentagem de transmitância para o filme Unipac-PE-60 oito dias após a irradiação com raios gama, no intervalo de dose de radiação entre 0 - 30 kGy.

45 Espectros de porcentagem de transmitância para o filme Unipac-PE-60 oito dias após a irradiação com feixe de elétrons, no intervalo de dose de radiação entre 0 - 30 kGy.

46 Espectros de porcentagem de transmitância para a estrutura Lovaflex $\mathrm{CH} 130$ oito dias após a irradiação com raios gama, no intervalo de dose de radiação entre 0 -30 kGy.

47 Espectros de porcentagem de transmitância para a estrutura Lovaflex $\mathrm{CH} 130$ oito dias após a irradiação com feixe de elétrons, no intervalo de dose de radiação entre 0 - $30 \mathrm{kGy}$

48 Taxa de permeabilidade ao vapor dágua em função da dose de radiação para o Unipac-PE-60 oito dias após a irradiação com raios gama ou com feixe de elétrons.

49 Taxa de permeabilidade ao vapor dágua em função da dose de radiação para o Unipac-PE-60 três meses após a irradiação com raios gama ou com feixe de elétrons.

50 Comparação entre os valores da taxa de permeabilidade ao vapor d'água do filme Unipac-PE-60 não irradiado, oito dias e três meses após a irradiação com raios gama ou com feixe de elétrons e o seu valor limite de segurança 
Figura

Título

Página

51 Taxa de permeabilidade ao vapor dágua em função da dose de radiação para a estrutura Lovaflex $\mathrm{CH} 130$ oito dias após a irradiação com raios gama ou com feixe de elétrons.

52 Taxa de permeabilidade ao vapor dágua em função da dose de radiação para a estrutura Lovaflex $\mathrm{CH} 130$ três meses após a irradiação com raios gama ou com feixe de elétrons.

53 Comparação entre os valores da taxa de permeabilidade ao vapor d'água da estrutura Lovaflex $\mathrm{CH} 130$ não irradiado, oito dias e três meses após a irradiação com raios gama ou com feixe de elétrons e o seu valor limite de segurança

54 Efeitos da dose de radiação na taxa de permeabilidade ao gás oxigênio para a estrutura Lovaflex $\mathrm{CH} 130$ oito dias após a irradiação com raios gama ou com feixe de elétrons.

55 Efeitos da dose de radiação na taxa de permeabilidade ao gás oxigênio para a estrutura Lovaflex $\mathrm{CH} 130$ três meses após a irradiação com raios gama ou com feixe de elétrons.

56 Comparação entre os valores da taxa de permeabilidade ao gás oxigênio da estrutura Lovaflex $\mathrm{CH} 130$ não irradiada, oito dias e três meses após a irradiação com raios gama ou com feixe de elétrons e o seu valor limite de segurança.

57 Comparativo da variação dos valores médios dos resíduos de migração total em n-heptano para o filme Unipac-PE60 irradiado com raios gama ou com feixe de elétrons.

$58 \quad$ Comparativo da variação dos valores médios dos resíduos de migração total em ácido acético a $3 \%$ para o filme Unipac-PE-60 irradiado com raios gama ou com feixe de elétrons.

59 Comparativo da variação dos valores médios dos resíduos de migração total em n-heptano para a estrutura Lovaflex $\mathrm{CH} 130$ irradiada com raios gama ou com feixe de elétrons. 
Figura

Título

Página

60 Comparativo da variação dos valores médios dos resíduos de migração total em ácido acético a 3\% para a estrutura Lovaflex $\mathrm{CH} 130$ irradiada com raios gama ou com feixe de elétrons. 


\section{INTRODUÇÃO}

A embalagem de produtos alimentícios ocupa um papel central na indústria moderna de alimentos e tem originado importantes avanços tecnológicos que demonstram cada vez mais um caráter interdisciplinar. A embalagem é considerada essencial e imprescindível na sociedade moderna, mas essa necessidade é quase tão antiga quanto a própria história do homem se lembrarmos que, em tempos muito remotos, pedaços de árvore, chifres, peles e bexigas de animais eram usados pelos primitivos para acondicionar alimentos ${ }^{[1,2]}$.

Num contexto moderno, ela é definida como uma função tecnoeconômica que visa proteger e distribuir produtos ao menor custo possível, além de aumentar as vendas e, consequentemente, os lucros. O aspecto de proteção é, portanto, imprescindível em diferentes fases da produção e vida de um produto e tem como alvo-final um consumidor cada vez mais consciente e exigente ${ }^{[2,3]}$.

O consumidor busca, cada vez mais, alimentos frescos e de boa qualidade, saudáveis, nutritivos, saborosos, com conveniência e facilidade de uso. De maneira a continuarem competitivos dentro deste segmento, os integrantes da Indústria Alimentícia não têm medido esforços na tentativa de reunir ao produto características que sejam simultaneamente mais atrativas para esse público e mais econômicas, como maior segurança, ausência de conservantes e aditivos e maior vida útil, entre outros ${ }^{[2-4]}$.

A fim de atender esse novo consumidor, aumentar a produtividade e eliminar ineficiências dentro do sistema produtivo e de distribuição, a palavra de ordem na indústria de alimentos e do setor de embalagens atual é alinhar-se a novas tecnologias e tendências ${ }^{[3-6]}$. 
Dentro desse objetivo, os processamentos por radiação ionizante para tratamento e conservação de alimentos, melhoria das propriedades dos materiais de embalagens e esterilização é uma das inovações tecnológicas que vem ganhando destaque considerável, especialmente nos países desenvolvidos. Esses processos têm se tornado cada vez mais representativos nos segmentos produtivos e de serviços, desde o setor de supermercados aos frigoríficos, passando pela indústria de alimentos processados e indústria de embalagens ${ }^{[6-9]}$.

O processamento por radiação ionizante com doses de radiação absorvida entre 0,3-70 kGy é conhecido como pasteurização a frio. Aplicado juntamente com os métodos tradicionais de tratamento e conservação de alimentos, pode reduzir o número de microorganismos patogênicos em produtos cárneos, seus derivados e outros alimentos. A pasteurização por radiação é capaz de controlar a transmissão de doenças originárias de alimentos contaminados, como a salmonelose, e reduzir as perdas durante as fases de estocagem, processamento, distribuição e comercialização, disponibilizando, para uma população mundial em expansão, alimentos sadios e seguros sem alteraração das suas propriedades nutricionais e organolépticas ${ }^{[8,10]}$.

Carnes de frango são irradiadas nos Estados Unidos desde 1993 para controle da Salmonela e, em dezembro de 1997, o "Food and Drug Administration" (FDA) aprovou a irradiação de carnes vermelhas resfriadas ou congeladas ${ }^{[\mathbf{8}, \mathbf{1 0}]}$. Essa medida renovou o interesse mundial na pasteurização por radiação de carnes frescas "in natura" e derivados pré-embalados, com vistas à manutenção da qualidade fitossanitária por longos períodos e à ampliação do alcance do sistema de distribuição desses produtos perecíveis. A irradiação de produtos cárneos é recomendada pela Organização Mundial de Saúde (OMS) e pela Comissão do "Codex Alimentarius". Esses produtos são irradiados préembalados, para prevenir a recontaminação microbiana ${ }^{[8-10]}$.

A indústria de embalagem tem usado a radiação ionizante para modificar as propriedades químicas, mecânicas, térmicas e de barreiras do seu 
produto final, de modo a extender o campo de aplicação e agregar valor. A reticulação por radiação aumenta a estabilidade térmica, a temperatura de serviço e o efeito memória, melhora a estabilidade dimensional e as propriedades mecânicas e de barreiras. Nos Estados Unidos, 90\% das aves congeladas são acondicionadas em filmes de polietileno reticulado por radiação. Grande atenção também tem sido dada à aplicação da radiação ionizante na esterilização de embalagens flexíveis para posterior acondicionamento de alimentos em condições assépticas ${ }^{[7,16]}$.

A função básica da embalagem é manter a integridade do produto até o seu consumo, alterando o microambiente ao seu redor, retardando reações de deterioração, prevenindo a evaporação da umidade do produto e evitando perdas de peso e alterações de aparência, textura e aroma ${ }^{[\mathbf{1 , 2}]}$.

A radiação pode causar mudanças estruturais nos materiais de embalagens, alterando suas propriedades mecânicas, químicas e de barreiras originais, entre outras. Os materiais utilizados para esse processamento devem apresentar resistência físico-química à radiação, não devem sofrer redução das suas características de proteção, nem transferir substâncias tóxicas ou causar odores e sabores estranhos ao produto acondicionado ${ }^{[16,17]}$. 


\section{OBJETIVOS E ASPECTOS RELEVANTES}

\subsection{Objetivo do trabalho}

A proposição principal do trabalho foi avaliar o efeito da radiação ionizante sobre as propriedades de filme flexível monocamada de polietileno, usado para o acondicionamento de aves (inteiras, carcaças e cortes), e de filme multicamadas coextrusado $\mathrm{PA}-\mathrm{CO} / \mathrm{EVOH} / \mathrm{PE}$, usado para acondicionar embutidos como salsichas, linguiças e frios fatiados, entre outros. Ambos os filmes são produzidos pela indústria nacional. Os parâmetros avaliados foram as propriedades mecânicas, ópticas e de barreiras, a formação de produtos voláteis e a migração total de contaminantes em simulantes de alimentos.

\subsection{Aspectos relevantes do trabalho}

O processo de radiopasteurização de produtos cárneos é recomendada por organizações internacionais como a Organização das Nações Unidas para a Agricultura e Alimentação (Food and Agriculture Organization - FAO) e a Organização Munidal da Saúde - OMS e é amplamente usada por diversos países. Nesse processo, os raios gama ou feixes de elétrons interagem com os microorganismos, quebrando ligações químicas em moléculas como o DNA, danificando-as e causando, como conseqüência, a inativação do microrganismo. Para evitar a recontaminação, os produtos são irradiados pré-embalados ${ }^{[9]}$.

Com vistas à qualidade fitossanitária dos alimentos, o Brasil aprovou, em janeiro de 2001, o "Regulamento Técnico para Irradiação de Alimentos ${ }^{\lceil\mathbf{1 8}]}$. Contudo, a irradiação comercial de carnes e derivados ainda não é uma realidade. Possivelmente, contribuem para isso a falta, no mercado nacional, de embalagens 
adequadas ao processo e de materiais de embalagens com comprovada resistência físico-química à radiação ionizante. 


\section{CONTRIBUIÇÃO E ORIGINALIDADE DO TRABALHO}

\subsection{Contribuição do trabalho}

> Contribuir com o desenvolvimento das aplicações da radiação ionizante em embalagens plásticas para alimentos, gerando informações e conhecimentos que venham favorecer a implementação comercial da pasteurização por radiação de produtos cárneos mantendo-se as propriedades funcionais e a qualidade fitossanitária dos produtos irradiados até a mesa do consumidor;

Gerar informações e conhecimentos com vistas a agregar valor à agroindústria brasileira da carne, para atender a demanda por qualidade em um mercado cada vez mais competitivo e com consumidores cada vez mais exigentes;

Demonstrar que a radiação ionizante pode contribuir para a conservação de alimentos tendo em mente que ela deve ser controlada, assim como também os aditivos incorporados à resina plástica para obtenção de embalagens para alimentos.

\subsection{Originalidade do trabalho}

A originalidade do trabalho baseou-se no fato de que a natureza e a extensão das mudanças químicas e físicas nos materiais plásticos são influenciadas pelo histórico do processamento e pelos aditivos incorporados.

Muitos dos aditivos adicionados às resinas e aos materiais de embalagens analisados nesta pesquisa são produtos nacionais utilizados, na maioria dos casos, exclusivamente dentro do território nacional. Salienta-se que esses materiais têm o seu próprio histórico de processamento e, além disso, foram 
fabricados para o acondicionamento convencional de produtos cárneos, não se conhecendo, portanto, a sua resposta à radiação ionizante. 


\section{REVISÃO BIBLIOGRÁFICA}

\subsection{Embalagens para produtos cárneos}

Produtos cárneos são alimentos que se deterioram com facilidade, por isso são classificados como altamente perecíveis. Os principais agentes da deterioração dos produtos cárneos são o crescimento microbiano, a oxidação da mioglobina, uma proteína pigmentada do tecido muscular, e a rancificação da gordura. Para reduzir riscos e garantir ao consumidor alimentos seguros, além de serem preparados e manipulados em conformidade com as boas práticas de fabricação ("Good Manufacturing Practices - GMP") é condição sine qua non que esses produtos sejam acondicionados em embalagens adequadas ${ }^{[2,19]}$. A combinação de procedimentos corretos de manipulação e preparo de carnes e derivados com o acondicionamento em embalagens adequadas, mantém a sua qualidade, propriedades funcionais e permitem que permaneçam seguros ao consumidor por longos períodos. A vida-de-prateleira mais longa possibilita uma ampliação do alcance do sistema de distribuição, se traduz em maiores possibilidades de mercado para a indústria de carnes e portanto, produtos de melhor qualidade ${ }^{[\mathbf{1 , 2}, \mathbf{2 0}]}$.

Define-se embalagens adequadas para carnes e produtos derivados aquelas, capazes de fornecer proteção contra fatores do meio ambiente, como oxigênio, luz, umidade e contaminação microbiológica, capazes de alterar o ambiente ao redor do produto, criando condições que retardam as reações de deterioração microbiológica, mantêm uma coloração desejável, previnem a evaporação da umidade e retardam a oxidação de gorduras do produto, evitando perdas de peso e alterações de aparência, textura e aroma e prolongando a vidade-prateleira do produto ${ }^{[1,3,19,20]}$. Além dos benefícios diretos ao consumidor final, a venda do produto embalado possibilita a comercialização de produtos com marca comercial, com benefícios econômicos e técnicos em termos de qualidade 
da carne. Assim, a indústria de produtos cárneos pode utilizar a embalagem e, conseqüentemente, o estilo de apresentação do produto para obter maior lucratividade $e^{[2,20]}$.

A embalagem influencia a qualidade e durabilidade de carnes frescas e derivados mas não poderá melhorar a qualidade inicial da carne, nem mesmo irá conservá-la indefinidamente. Porém, a boa qualidade do produto antes do acondicionamento é fundamental, uma vez que as reações de oxidação acontecem via radical livre e em cadeia, produzindo compostos (aldeídos, cetonas, hidrocarbonetos, ésteres, entre outros) responsáveis pela mudança de sabor e odor do produto. Após um período de estocagem, é inevitável que ocorra certa perda de qualidade no produto acondicionado, cuja velocidade é determinada pelas características do produto, contaminação microbiana inicial, temperatura de estocagem, higiene no manuseio e pelas características da embalagem e do sistema de acondicionamento ${ }^{[\mathbf{1 - 4}, \mathbf{2 0 , 2 1 ]}}$.

Os primeiros materiais de embalagens usados para produtos cárneos nos tempos modernos foram o papel e o papelão, que tinha como função conter quantidades previamente pesadas de produtos cárneos "in natura", eram fáceis de estocar, transportar e empilhar, além de higiênicas, e as latas de estanho, para os produtos cárneos processados ${ }^{[4]}$.

Após a $2^{\mathrm{a}}$ Guerra Mundial, surgiram inúmeras inovações na produção de embalagens e um novo material para embalagens, o plástico. As resinas plásticas, como o polietileno, o poliéster, foram introduzidas na fabricação de embalagens no pós guerra. A partir dos anos 60 , cresceu a produção de embalagens plásticas e desde então o seu uso para embalagens de alimentos tem tomado o lugar do papel e do papelão, do vidro ou do metal ${ }^{[1,19,22-24]}$. Dos anos 70 até os dias atuais, a indústria brasileira de embalagem para produtos cárneos vem acompanhando as tendências mundiais ${ }^{[4]}$. As vantagens dos plásticos sobre os outros materiais de embalagens são numerosas ${ }^{[1,19,22-24]}$ : 
$>$ baixo custo;

peso muito menor;

maior dificuldade de quebrar ou de afetar o produto pelo próprio material;

> favoráveis para o meio ambiente (menor custo energético);

$>$ transparência;

$>$ flexibilidade;

> aprovados para o contato direto com o alimento;

$>$ podem ser aquecidos em fornos de microondas.

\subsubsection{Polímeros e embalagens plásticas flexíveis}

\subsubsection{Conceito de polímero}

A palavra polímero origina-se do grego poli (muitos) e mero (unidades de repetição). Os polímeros são macromoléculas compostas por muitas (dezenas de milhares) unidades de repetição denominadas meros, ligadas por ligações primárias fortes, chamadas intramoleculares, sendo do tipo covalente. Essas macromoléculas são formadas a partir de pequenas moléculas, com uma (mono) unidade de repetição, denominadas monômeros, que se ligam entre si para formar a cadeia polimérica ${ }^{[22,23]}$.

Quanto as propriedades mecânicas os polímeros podem ser divididos em três grandes classes, a saber: Plásticos, Borrachas e Fibras, dependendo do tipo de monômero (estrutura química), do número médio de meros por cadeia e do tipo de ligação covalente. Em relação a estrutura molecular, as cadeias poliméricas podem ser lineares, ramificadas, com ligações cruzadas e em rede $\mathrm{i22,23]}^{\text {. }}$

Quanto ao modo como as cadeias moleculares estão empacotadas os polímeros podem ser inteiramente amorfos, quando o empacotamento é desordenado, ou semi-cristalinos quando o empacotamento de segmento de 
cadeias é ordenado, regular e repetitivo. Nas regiões cristalinas do polímero ocorrem 0 alinhamento dos segmentos de cadeias em um arranjo tridimensionalmente perfeito. A cristalinidade é facilitada no caso de polímeros que são quimicamente simples ou possuem estruturas de cadeias regulares e simétricas. A maioria das propriedades físicas, mecânicas e termodinâmicas dos polímeros semi-cristalinos depende do grau de cristalinidade e da morfologia das regiões cristalinas. Quanto maior a cristalinidade, mais elevadas são as propriedades de densidade, rigidez, estabilidade dimensional, resistência química, resistência à abrasão, temperatura de fusão $\left(T_{m}\right)$, temperatura de transição vítrea $\left(T_{g}\right)$ para um dado polímero; e menores são as suas propriedades de resistência ao impacto, elongação na ruptura e claridade ótica, entre outras ${ }^{[22,23]}$.

\subsubsection{Outros conceitos}

Macromolécula - molécula de alta massa molar, mas que não tem necessariamente em sua estrutura uma unidade de repetição ${ }^{\text {[22] }}$.

Monômero - molécula simples que dá origem ao polímero. Deve ter funcionalidade de no mínimo 2, ou seja, ser pelo menos bifuncional ${ }^{[22]}$.

Mero - unidade de repetição da cadeia polimérica[22].

Elastômero - polímero que à temperatura ambiente pode ser deformado repetidamente a pelo menos duas vezes o seu comprimento original. Retirado o esforço, deve voltar rapidamente ao tamanho original ${ }^{[22]}$.

Homopolímero - polímero formado a partir de um único monômero, ou aquele em que a cadeia principal é formada por um único mero ${ }^{[22]}$.

Copolímero - polímero cuja cadeia principal é formada por dois meros diferentes ${ }^{[22]}$. 
Poliolefinas - são polímeros originários de monômeros de hidrocarboneto alifática insaturado, contendo uma dupla ligação carbono-carbono reativa. Dentro desta classificação, temos o polibuteno, o poli-4-metil-penteno-1, e os dois polímeros mais utilizados no mundo, o polietileno - PE e o polipropileno PP, que representam pelo menos metade de todo o polímero produzido mundialmente ${ }^{[22]}$.

Plásticos - o termo plástico vem do grego e significa "adequado à moldagem". Os plásticos são materiais que contêm, como componente principal, um polímero orgânico sintético. Apresentam-se sólidos à temperatura ambiente em seu estado final, tornando-se, em algum estágio de seu processamento, fluidos e possíveis de serem moldados, por ação isolada ou conjunta de calor e pressão[31].

As propriedades e aplicações dos plásticos dependem da natureza física e química dos polímeros utilizados, as quais são determinadas pela natureza dos monômeros, pela estrutura e massa molar das cadeias poliméricas, pelo grau de cristalinidade e pelo nível de interação ente as cadeias dos polímeros ${ }^{[\mathbf{1}, \mathbf{1 9}, \mathbf{2 2 - 2 4}]}$.

Termoplásticos - são polímeros com a capacidade de amolecer e fluir quando sujeitos a um aumento de temperatura e pressão, ou seja, sob pressão e calor, passam por uma transformação física, mas não sofrem mutação em sua estrutura química, e se tornam reversíveis, isto é, podem ser moldados de diversas formas e repetidamente, normalmente com $\mathrm{o}$ auxílio de calor e pressão $^{[1,22-24]}$.

Termofixo ou termorrígido - são polímeros que amolece uma vez com o aquecimento e sofre o processo de cura tornando-se rígido. Após a cura, ele é infusível e insolúvel, assim, aquecimentos posteriores não alteram mais seu estado físico, ou seja, não os amolecem mais ${ }^{[1,22-24]}$. 
Aditivos - todo e qualquer material adicionado a um polímero visando a uma aplicação específica. Os aditivos são componentes indispensáveis nos materiais poliméricos para embalagens e de fundamental importância, tanto para melhorar suas propriedades físico-químicas e ampliar sua faixa de aplicação, mas também pelo apelo visual e para conferir estabilidade ao material durante 0 serviço e o processamento. Todos os materiais plásticos de embalagens comerciais são aditivados, seja quando da síntese e processamento do polímero, ou durante a sua transformação. Os aditivos mais utilizados são[22, 24]:

Aditivos auxiliares de polimerização: catalisadores, iniciantes, agentes de reticulação, entre outros;

$>$ Axiliares de processamento: lubrificantes, auxiliares de fluxo poliméricos, solventes;

> Etabilizantes: antioxidantes, estabilizantes térmicos, desativadores de metais, estabilizantes de ultravioleta, preservativos;

> Aditivos modificadores de propriedades: antiestáticos, retardantes de chama, pigmentos, plastificantes, cargas, agentes de reticulação, agentes de expansão, nucleantes.

Adesivo - substância (normalmente polimérica) capaz de manter materiais unidos (colados) por adesão superficial. Podem ser tanto rígidos quanto flexíveis ${ }^{[22]}$.

Degradação - pode ser definida como uma série de reações químicas que envolvem também ruptura das ligações da cadeia principal da macromolécula, normalmente com redução da massa molar e consequentemente queda nas propriedades físico-mecânicas; modificação química destrutiva, com a quebra de ligações covalentes e formação de novas ligações. Como exemplo pode-se citar: oxidação, hidrólise, cisão de cadeia, entre outras ${ }^{[22,24]}$.

Reticulação - é a formação de ligações intermoleculares na cadeia polimérica. Na reticulação as moléculas poliméricas se ligam quimicamente, 
formando uma única molécula, de massa molar média maior. A reticulação de termoplásticos pode ser iniciada por radiação ionizante ou por iniciadores químicos (agentes de reticulação) como os peróxidos orgânicos, compostos à base de enxofre, amidas, aminas, silanos, entre outros. Do ponto de vista de materiais de embalagens, esse processo tem como objetivo conferir aos materiais determinadas propriedades, tais como: maior resistência química, maior resistência à degradação térmica, melhores propriedades adesivas, melhores propriedades de barreiras, maior estabilidade ao calor e menor fluência, entre outas $^{[1,21,25-27]}$.

Embalagens plásticas flexíveis - são embalagens cujos formatos dependem da forma física do produto acondicionado em seu interior, são feitas de filmes plásticos finos e flexíveis e tem a capacidade de "embalar e selar" os produtos hermeticamente por meio de máquinas de envase especiais. Os materiais flexíveis devem ter propriedades mecânicas especiais, tendo a característica de selagem por pressão fria ou quente, protegendo os produtos de agentes internos e externos. Assim, estes materiais se destacam pela flexibilidade que oferecem ao dimensionamento de suas propriedades e pela relação otimizada de massa de embalagem/quantidade de produto acondicionado ${ }^{[\mathbf{1}, \mathbf{2 1}, \mathbf{2 4}]}$.

As embalagens plásticas flexíveis podem ser: monocamadas - são embalagens de um só tipo de material impresso ou não; multicamadas - são embalagens compostas por dois ou mais tipos de materiais para aproveitar as características de cada um. As embalagens multicamadas têm por objetivo a integração de propriedades de diferentes materiais termoplásticos em uma única embalagem, de modo a atender as exigências de conservação, de proteção, de visual e custo do produto acondicionado, entre outras, como as propriedades

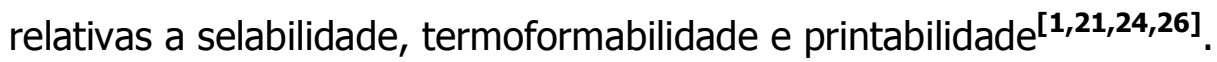

As embalagens multicamadas têm encontrado excelente mercado na indústria de carnes e derivados em razão da sua potencialidade de conjugar propriedades como transparência ou opacidade, resistência mecânica, rigidez ou 
flexibilidade, como também barreira contra gases e contra umidade. A composição das camadas varia de acordo com o tipo de produto a ser embalado, necessidade de barreira e custo do material, bem como, das combinações de propriedades e do nível de eficiência desejados. O crescimento do uso de multicamadas na indústria de carnes é consequência também da possiblidade de se produzir embalagens eficientes com o mínimo de material e com o mais baixo peso possível[1,20,21,26].

Filme plástico - segundo Brody e Marsh ${ }^{[28]}$, filme plástico é definido como uma estrutura flexível relativamente fina, com espessura geralmente infeiror a $254 \mu \mathrm{m}$ (valor correspondente a 10 milésimos de polegada), obtida a partir de um ou mais polímeros blendados ou coextrusados.

Extrusão - denomina-se extrusão a passagem forçada de um metal ou de um plástico através de orifício, visando conseguir uma forma alongada ou filamentosa. Na indústria de produção de artefatos plásticos, a extrusão é um processo de transformação de termoplásticos no qual o processo é realizado a partir da fusão e homogeneização do material a uma dada vazão, pressão e temperatura, consiste, de forma geral, em bombear um polímero que foi aquecido até tornar-se uma massa fluida através de uma matriz, produzindo-se um perfil contínuo ${ }^{[1,24,28]}$.

A extrusão é o processo básico mais utilizado atualmente para transformar grãos e pós poliméricos em filmes. É empregado tanto para a fabricação de filmes monocamada, ou estruturas multicamadas (co-extrusão) como de outros perfis contínuos, por exemplo, chapas, fibras e tubos, cobertura de fios elétricos entre outros. O segmento da indústria que fabrica filmes plásticos utiliza dois tipos de extrusão: extrusão por sistema balão (chamada na indústria de sistema de extrusão "blown') e o sistema de extrusão plana ${ }^{[\mathbf{1 , 2 4 , 2 8}]}$.

Co-extrusão - o processo de co-extrusão é semelhante ao de monoextrusão, porém na co-extrusão cada material é plastificado numa extrusora 
específica. Cada extrusora homogeniza e plastifica o seu material em condições ótimas individuais de trabalho e o introduz em um único cabeçote que receberá também todos os outros materiais. Estes sairão juntos da matriz em multicamadas ${ }^{[1,24,28]}$.

O processo de co-extrusão aumenta enormemente a capacidade dos filmes plásticos usados em embalagens, pois possibilita a combinação das propriedades de vários polímeros em uma mesma estrutura ${ }^{[1,21,24]}$.

Os filmes, objeto deste trabalho, foram fabricados em máquinas extrusora (monocamada LDPE) e co-extrusora (estrutura Lovaflex $\mathrm{CH} 130$ ) do tipo balão.

Termoformagem - é a deformação de chapas plásticas aquecidas para a produção de recipientes numa variada gama de processos genericamente englobados sob a designação de processos de termoformagem ${ }^{[24]}$.

\subsubsection{Polímeros usados como materiais de embalagem}

\subsection{Polietileno - "PE"}

Desenvolvido comercialmente em 1940, o polietileno é o plástico de mais ampla utilização e o mais vendido no mundo atualmente. $O$ seu elevado consumo deve-se ao preço reduzido, facilidade de processamento, isenção de toxicidade, ser não higroscópico e versátil. O polietileno pode ser quase transparente ou translúcido, rígido ou flexível, natural ou pigmentado. Com ele são feitos sacos e sacolas, garrafas, utensílios domésticos, brinquedos, frascos e ampolas para cosméticos e medicamentos, tanques de combustíveis para veículos, peças automotivas, baldes, bombonas para produtos químicos diversos e até coletes à prova de balas. 
Na FIG.1 é apresentada uma representação da estrutura do polietileno.

\section{$\left.-\mathrm{CH}_{2}-\mathrm{CH}_{2}\right]_{\mathrm{n}}$}

FIGURA 1 - Representação da estrutura do polietileno

$\mathrm{O}$ PE é resistente à maioria dos produtos químicos, exceto ácidos oxidantes, halogênios livres e certas cetonas. À temperatura ambiente, são insolúveis em praticamente todos os solventes. A solubilidade em hidrocarbonetos e hidrocarbonetos clorados aumenta rapidamente com o aumento da temperatura. Em razão da boa resistência mecânica, baixo custo, do equilíbrio de suas propriedades de selagem, da atoxicidade e excelente barreira ao vapor d'água, é o plástico mais usado em embalagens de alimentos, podendo ser usado em contato direto com estes. Não é barreira a gases e é permeável a óleos e gorduras $^{[24,29,30]}$.

As aplicações do PE em embalagens são muitas, ele é usado sozinho, em filmes simples (monocamada) ou como camada em estruturas coextrusadas ou laminadas com outros polímeros ou com papel cartão ${ }^{[24,29,30]}$.

Embora o polietileno seja um material muito versátil, a sua estrutura é muito simples, possivelmente a mais simples entre os polímeros comerciais. É caracterizado pela extrema regularidade e flexibilidade de sua cadeia molecular, uma cadeia longa de átomos de carbono com átomos de hidrogênio unidos a cada átomo de carbono. O politietileno é obtido pela polimerização do monômero gasoso $\left(\mathrm{CH}_{2}=\mathrm{CH}_{2}\right)$ em reator sob determinadas condições de temperatura e pressão, pode ser produzido por meio de vários processos e tem características próprias de densidade, massa molar e distribuição de massa molar dependendo do processo de produção. Os polietilenos podem ser lineares ou ramificados, homo ou copolímeros. A densidade é o parâmetro mais importante que governa as suas propriedades e em função dela são classificados em ${ }^{[24,29,30]}$ : 
> Polietileno de Baixa Densidade (LDPE); 0,910-0,940 g/cm ${ }^{3}$

> Polietileno de Baixa Densidade Linear (LLDPE); 0,915 - 0,925 g/cm ${ }^{3}$

> Polietileno de Média Densidade (MDPE); 0,926-0,940 g/cm ${ }^{3}$

$>$ Polietileno de Alta Densidade (HDPE); 0,960 - 0,970 g/cm ${ }^{3}$

$>$ Polietileno de Ultra-Alta Massa Molar (UHMWPE); $0.940-0.950 \mathrm{~g} / \mathrm{cm}^{3}$

As propriedades ideais do "grade" de polietileno para cada aplicação específica dependem do balanço adequado de características obtidas no processo de polimerização. Os polietilenos são essencialmente constituídos de uma fase cristalina rígida (responsável pela resistência) e uma fração amorfa elástica (elasticidade, maciez e flexibilidade). Quanto menor o grau de ramificação e o comprimento das cadeias poliméricas, maior a cristalinidade e a densidade. Quando não há ramificações, o polietileno se chama linear (polietileno de alta densidade - "HDPE" ; polietileno de ultra-alta massa molar - "UHMWPE") ${ }^{[21,29-31]}$.

O polietileno linear HDPE é produzido por meio de um processo de polimerização que utiliza um catalisador estereoespecífico, denominado ZieglerNatta, dito processo de baixa pressão, porque ocorre em temperaturas e pressões mais baixas que o processo de polimerização do LDPE. O HDPE é produzido em massas numa faixa de 200.000 a $500.000 \mathrm{~g} / \mathrm{mol}$, podendo ser maior. Destaca-se a sua aplicação como embalagem de produtos que necessitam cocção dentro da própria embalagem por apresentar uma temperatura de amolecimento maior que $100^{\circ} \mathrm{C}$, diferentemente do LDPE que amolece antes dos $100^{\circ} \mathrm{C}^{[\mathbf{2 1}, \mathbf{2 9 - 3 1 ]}}$.

O UHMWPE é fabricado por meio da polimerização catalisada por metalocenos, com massas molares de três a seis milhões, porém não tem aplicações no segmento de embalagens para produtos cárneos ${ }^{[21]}$.

O polietileno de baixa densidade (LDPE) é obtido em condições de alta pressão e alta temperatura por um processo de polimerização por radicais livres. A polimerização aleatória do polietileno nessas condições produz um polímero 
ramificado, que possui menor cristalinidade, entre 40 e $60 \%$ e densidade entre 0,910 a $0,940 \mathrm{~g} / \mathrm{cm}^{3 \text { [21, 31,32]. }}$

O polietileno de baixa densidade linear (LLDPE) é similar ao LDPE, exceto pelas ramificações de cadeia que são mais curtas, o que confere maior linearidade às suas moléculas. Ele é fabricado por meio da polimerização catalisada por metalocenos. A densidade é controlada pela adição de comonômeros, tais como buteno, hexeno ou octeno, que regulam o tamanho das ramificações adicionadas às cadeias: dois carbonos para o buteno, quatro para o hexeno e seis para o octeno. As propriedades do LLDPE encontram-se geralmente entre às do LLDPE e do HDPE; baseada no efeito do tamanho das ramificações da cadeia $^{[21,30-32]}$.

O polietileno de média densidade (MDPE) pode ser obtido pelo processo de alta ou baixa pressão. O MDPE obtido pelo processo de alta pressão é caracterizado por um alto grau de ramificações longas e curtas ao longo da cadeia principal, já o obtido pela polimerização em baixa pressão apresenta ramificações de menor número e comprimento[24, 30, 32].

\subsection{Polipropileno - "PP"}

O polipropileno isotático foi desenvolvido em 1957 e introduzido no mercado por volta de 1959. O PP homopolímero é um polímero olefínico obtido pela polimerização do propileno, ou pela copolimerização do propileno com o etileno. É quimicamente resistente a praticamente todas as substâncias por um período de tempo não muito longo, mas pode amolecer na presença de solventes não polares quando o tempo de contato é grande. Apresenta densidade específica da ordem de $0,9 \mathrm{~g} / \mathrm{cm}^{3}$, barreira ao vapor d'água, boa estabilidade térmica, estabilidade dimensional, transparência, translucidez e resistência ao "stress cracking", temperatura de fusão cristalina entre 140 e $150^{\circ} \mathrm{C}$ e temperatura de 
transição vítrea entre +10 e $-20^{\circ} \mathrm{C}$, o que não permite que seja utilizado normalmente como embalagem para congelamento ${ }^{[21,24,30,33]}$.

Na FIG. 2 é apresentada uma representação da estrutura do polipropileno.

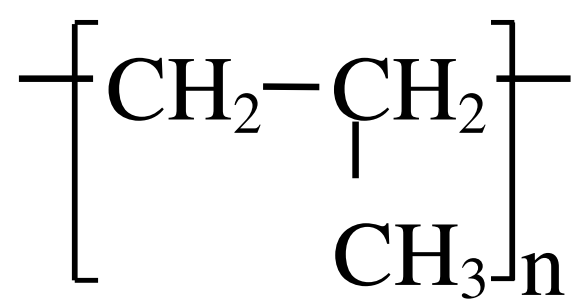

FIGURA 2 - Representação da estrutura do polipropileno

O PP obtido pela copolimerização com o etileno, quando comparado com o homopolímero, apresenta maior resistência à tração, menor rigidez, menor temperatura de transição vítrea e de fusão cristalina. Estas propriedades fazem do copolímero de PP um material bastante versátil, podendo ser utilizado em aplicações que passam por tratamentos térmicos severos, como a esterilização por calor, e também o congelamento, o que aumenta significativamente o tempo de vida de prateleira do produto embalado ${ }^{[21,24,30,33]}$.

\subsection{Poliamida - "PA"}

As poliamidas são polímeros que contém muitos grupos amidas na sua estrutura molecular com muitas variações da cadeia de carbono entre elas. As PA são, comumente chamadas de náilon, derivado do inglês "nylon", um nome genérico da família das poliamidas sintéticas, inicialmente uma marca comercial da empresa Dupont ${ }^{[21,23,24]}$.

As PA apresentam na sua fórmula estrutural, dois átomos carregados, o oxigênio ( $\delta$ - ) da carbonila e o nitrogênio $(\delta+)$ da amida que conferem aos mesmos características polares. Estes grupos funcionais exibem uma forte atração 
um ao outro e tendem a alinhar-se por ligações intermoleculares fortes chamadas pontes de hidrogênio ${ }^{[34,35]}$.

Na FIG. 3 é apresentada, a título de ilustração, uma representação estrutural de uma poliamida.

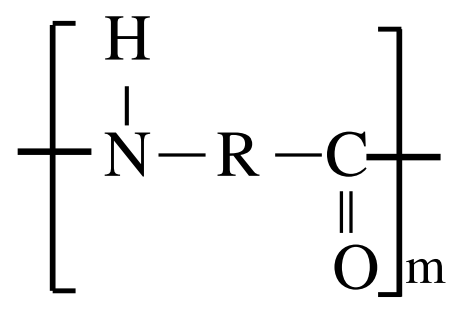

na qual,

$$
\mathrm{R}=\left(\mathrm{CH}_{\mathbf{2}}\right)_{\mathbf{n}}
$$

quando:

$\mathrm{n}=2 \Rightarrow \mathrm{R}=\left(\mathrm{CH}_{2}\right)_{\mathbf{2}}=$ Poliamida 3 (PA 3)

$\mathrm{n}=4 \Rightarrow \mathrm{R}=\left(\mathrm{CH}_{2}\right)_{4}=$ Poliamida 5 (PA 5)

$\mathrm{n}=10 \Rightarrow \mathrm{R}=\left(\mathrm{CH}_{\mathbf{2}}\right)_{\mathbf{1 0}}=$ Poliamida $11(\mathrm{PA} 11)$

FIGURA 3 - Representação estrutural de uma poliamida

As poliamidas têm boa barreira a gases e a aromas, apresentam alta resistência mecânica (abrasão, perfuração, impacto, flexão), boa resistência térmica, boa resistência a óleos e gorduras, a produtos químicos e podem ser termoformadas. Resistem a álcalis e a ácidos diluídos, mas reagem com ácidos fortes e agentes oxidantes. As maiores deficiências das poliamidas são a baixa barreira ao vapor d'água e a perda de propriedades mecânicas e de barreira com a umidificação. A umidade exerce um efeito plastificante no polímero, causando uma redução na resistência à tração e no módulo de elasticidade, na rigidez e nas

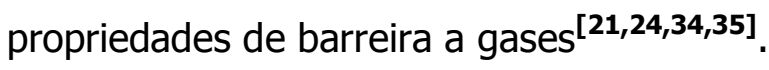

$\mathrm{Na}$ área de embalagens a maior parte das poliamidas é utilizada na forma de filmes. Os filmes podem ser fabricados por extrusão plana ou tubular, ser mono ou bi-orientados. Os filmes não orientados são utilizados para termoformação, geralmente em filmes coextrusados com o LDPE ou EVA, o que alia as propriedades de selagem e barreira ao vapor d'água às excelentes propriedades mecânicas e de barreira a gases das PA. Atualmente, são utilizadas 
pela indústria de embalagens flexíveis, preferencialmente, três tipos de poliamidas: a PA 6, a PA 6.6 e o copolímero PA $6,6.6^{[21,24,35]}$.

$>$ PA 6

A poliamida 6 (PA 6) é obtida a partir da $\varepsilon$-caprolactama, que é um composto orgânico que possui 6 átomos de carbono na sua composição, originando a PA 6 cujo mero é também constituído por 6 átomos de carbono[21,26,29].

Na FIG. 4 é apresentada uma representação da estrutura da poliamida 6 (PA 6).

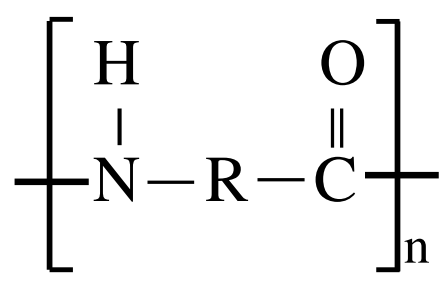

na qual,

$\mathrm{R}=\left(\mathrm{CH}_{2}\right)_{5}$

FIGURA 4 - Representação da estrutura da poliamida 6 (PA 6)

\section{PA 6.6}

Possui 12 átomos de carbono no mero, originários de cada uma das matérias primas que a constitui, é obtida a partir da policondensação do ácido adípico, que possui 6 átomos de carbono com hexametilenodiamina que também tem 6 átomos de carbono ${ }^{[21,26,29]}$.

Na FIG. 5 é apresentada uma representação da estrutura da poliamida 6.6 (PA 6.6). 


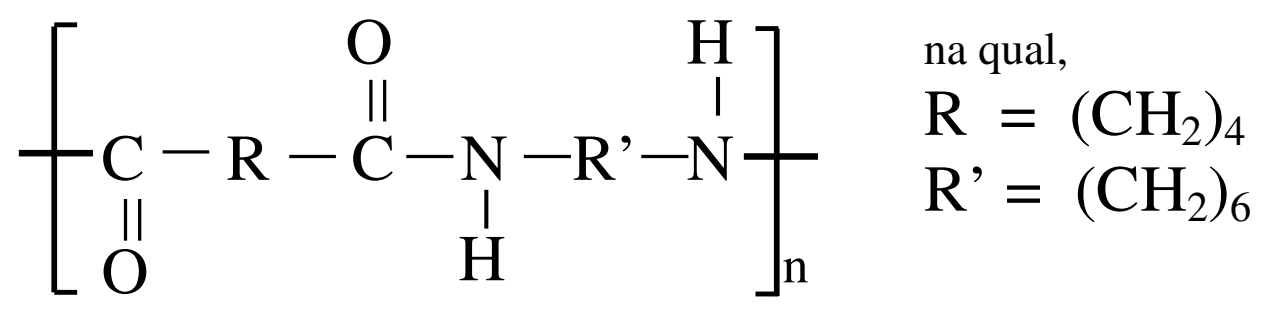

FIGURA 5 - Representação da estrutura da poliamida 6.6 (PA 6.6)

PA 6, 6.6

O copolímero PA 6, 6.6, é obtido pela copolimerização por condensação a $\varepsilon$-caprolactama com hexametilenodiamina e ácido adípico ${ }^{[21,26]}$.

Na FIG.6 é apresentada uma representação da estrutura da copoliamida 6, 6.6 (PA 6, 6.6).

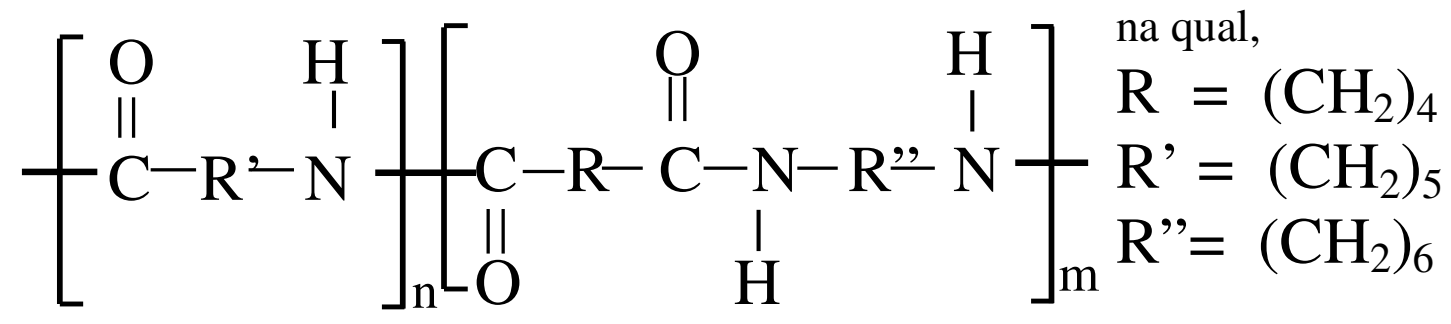

FIGURA 6 - Representação da estrutura da copoliamida 6, 6.6 (PA 6, 6.6)

\subsection{Copolímero de etileno e acetato de vinila - "EVA"}

O copolímero de etileno e acetato de vinila - "EVA" é um copolímero randônico de etileno e acetato de vinila, cujas propriedades dependem do teor de acetato de vinila (VA). Sua resistência ao impacto aumenta conforme aumenta o 
teor de VA e a massa molar. É um polímero de cristalinidade baixa e muito elástico. Nas aplicações em embalagens flexíveis apresentam um teor de VA entre 3 e $12 \%$, acima de $12 \%$ são usados como adesivos. O aumento da porcentagem de VA na molécula aumenta sua polaridade e consequentemente aumenta a flexibilidade e a faixa de selagem do material, como também, aumenta a resistência da termoselagem ainda a quente. Quanto maior o teor de VA, o EVA é menos cristalino e mais elástico. A redução na cristalinidade leva a um aumento na permeabilidade a gases e ao vapor d'água, e da permeação à gordura ${ }^{[21,24,32]}$.

Na FIG. 7 é apresentada uma representação da estrutura do copolímero de etileno e acetato de vinila - EVA.

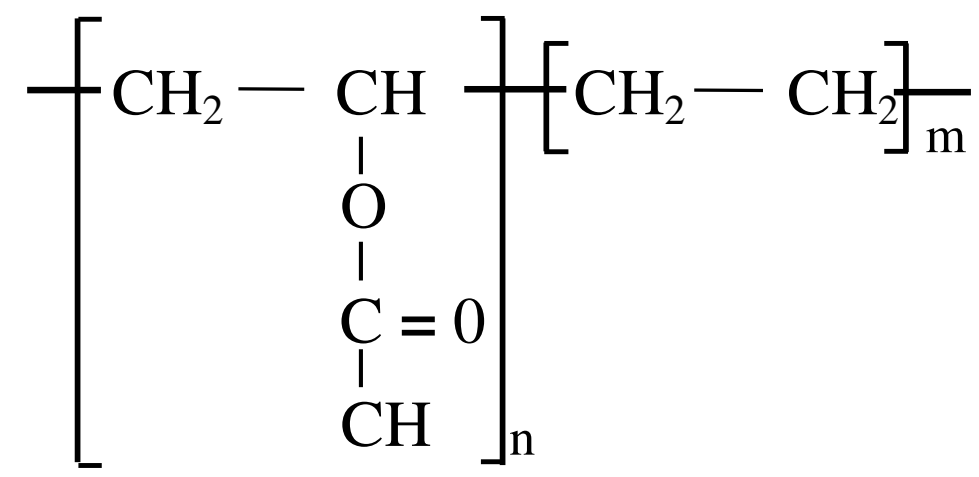

FIGURA 7- Representação da estrutura do copolímero de etileno e acetato de vinila - EVA

O EVA é um polímero de aplicação restrita em embalagens flexíveis, pois tem alta tendência ao bloqueio e atrito, o que dificulta sua maquinabilidade. $O$ EVA solda com maior facilidade quando comparado ao $\mathrm{PE}$, é geralmente mais transparente, sendo mais indicado para embalagens que necessitam alto grau de estiramento e encolhimento. Devido às propriedades de adesão e de selagem é utilizado como revestimento ou como camada interna em estruturas coextrusadas $^{[21,24,32]}$. 
O EVA é produzido no mesmo processo utilizado para a produção do polietileno de baixa densidade. Trata-se de uma síntese em massa em que o polímero é dissolvido no próprio monômero, em altíssimas pressões (2.500 a $3.000 \mathrm{~atm})$. 0 gás etileno entra no reator tubular previamente comprimido e recebe as dosagens de VA. A polimerização inicia por meio da adição de um iniciador $^{[21,33]}$.

\subsection{Copolímero de etileno e álcool vinílico - "EVOH"}

O copolímero de etileno e álcool vinílico - EVOH é obtido pela hidrólise controlada do copolímero EVA, que transforma em álcool vinílico o grupo vinila. A sua baixa concentração de etileno assegura excelentes propriedades de barreira a gases, a odor, a sabor e especialmente ao oxigênio ${ }^{[21,24,36]}$.

Na FIG. 8 é apresentada uma representação da estrutura do copolímero de etileno e álcool vinílico - EVOH

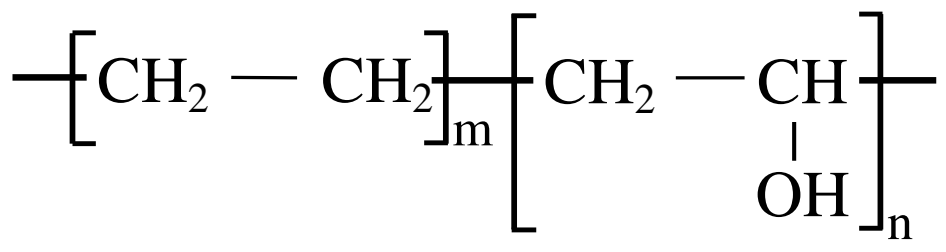

FIGURA 8 - Representação da estrutura do copolímero de etileno e álcool vinílico $-\mathrm{EVOH}$

Devido à sua elevada higroscopicidade e ao aumento da permeabilidade com absorção de água, a resina EVA passa por uma secagem antes do processamento e é preferencialmente processada em coextrusão onde encontra a proteção de camadas de baixa permeabilidade ao vapor d'água. As condições de umidade afetam a taxa de permeabilidade ao oxigênio de materiais hidrofílicos como o nylon, o EVOH e o celofane. A água absorvida pelo polímero age como um 
plastificante, associa-se às cadeias do polímero dando mobilidade e permitindo uma maior difusão do oxigênio no polímero ${ }^{[21,24,33]}$.

\subsubsection{Embalagens plásticas flexíveis}

Comercialmente, as embalagens mais comuns para carne fresca "in natura" têm sido os filmes plásticos flexíveis a base de policloreto de vinila (PVC), polietileno (PE) e outros polímeros poliolefínicos, e filmes mono ou multicamadas coextrusados, esticáveis ou encolhíveis ${ }^{[19,20]}$.

Os filmes plásticos de altíssima permeabilidade ao oxigênio, na faixa de 8.000 a $20.000 \mathrm{~cm}^{3} / \mathrm{m}^{2} / 24$ horas, não exercem controle sobre a deterioração microbiana e são geralmente usados com carnes frescas bovinas, porque podem manter a coloração vermelha, ao mesmo tempo que protegem o produto da desidratação superficial[ ${ }^{[\mathbf{1 9}, 20]}$.

No acondicionamento da carne fresca bovina, é recomendável que a taxa de permeabilidade ao oxigênio do material de embalagem seja a maior possível, para facilitar a oxigenação da superfície da carne e manter a cor vermelha brilhante. Os filmes de LDPE monocamada, devido ao fato de sua taxa de permeabilidade ao oxigênio não ser muito alta, normalmente inferior a 8.000 $\mathrm{cm}^{3} / \mathrm{m}^{2} / 24$ horas, não são recomendados para embalagens de varejo de carne bovina in natura, pois favorecerão o escurecimento rápido do produto. Contudo, são usados no transporte de carcaças e em peças grandes de carnes bovina ${ }^{[19-21]}$.

Os filmes mono ou multicamadas coextrusados, esticáveis ou encolhíveis, com espessura bem reduzida e permeabilidade ao oxigênio na faixa de 3.000 a $20.000 \mathrm{~cm}^{3} / \mathrm{m}^{2} / 24$ horas a $25^{\circ} \mathrm{C}$ e $1 \mathrm{~atm}$, têm sido utilizados para carnes frescas de aves. Os filmes de LDPE e de LLDPE são muito usados para aves inteiras, carcaça e cortes de aves. O polietileno e outras poliolefinas especiais 
conferem à estrutura resistência mecânica, características termoselantes e de barreira ao vapor d'água ${ }^{[19-21]}$.

Atualmente, seguindo a tendência do mercado mundial, observa-se um crescimento do mercado brasileiro de carnes e derivados embalados a vácuo. Os filmes para embalagens a vácuo podem ser encolhíveis ou não-encolhíveis, termoformáveis ou na forma de sacos. A combinação de diversos polímeros no filme, que posteriormente é transformado em sacos ou termoformado, fornecerá uma variedade de estruturas com diferentes níveis de barreira ao gás oxigênio e ao vapor d'água e muita proteção mecânica. ${ }^{[19-21,26]}$

Os principais requisitos de uma embalagem à vácuo destinada a acondicionar produtos cárneos, são a hermeticidade, a compatibilidade com o produto e a resistência mecânica. A hermeticidade assegura a não-interação do produto com o meio externo, evitando a penetração de microrganismos, gases e umidade e, permitindo a manutenção da esterilidade comercial do conteúdo após o processamento. A embalagem deve impedir a passagem de oxigênio e luz, prolongando a vida útil do produto acondicionado ${ }^{[19-21]}$.

As embalagens termoformadas são uma alternativa para o acondicionamento a vácuo de carnes processadas, como a salsicha, a linguiça, frios fatiados e outros. Neste sistema utilizam-se dois tipos de filmes, um de fundo, que é termoformado em bandeja, e outro para tampa, que é geralmente coextrusado flexível e transparente, com impressão externa ou interna ${ }^{[19-21]}$.

Os filmes de tampa e de fundo devem apresentar de média a alta barreira a gases, dependendo da aplicação. Contudo, o filme de fundo precisa manter essa propriedade após a termoformação, por causa da redução de espessura causada pelo estiramento feito nas máquinas de termoformação ${ }^{[\mathbf{1 9}, \mathbf{2 0}}$.

Uma alternativa para aumentar a barreira a gases dos filmes de alta barreira à gases, é a utilização do $\mathrm{EVOH}^{[21,36,37]}$. As estruturas com $\mathrm{EVOH}$ 
apresentam taxa de permeabilidade ao oxigênio na faixa de 0,5 a 10 $\mathrm{cm}^{3} / \mathrm{m}^{2} / 24$ horas a $25^{\circ} \mathrm{C}$ e $1 \mathrm{~atm}$ e com PA entre 18 a $105 \mathrm{~cm}^{3} / \mathrm{m}^{2} / 24$ horas. A PA atua como barreira ao oxigênio, ao mesmo tempo que confere ao material boa resistência mecânica. Normalmente a PA está presente nestas estruturas, para melhorar a distribuição de espessura da camada barreira após a termoformação ${ }^{[3,19-21]}$.

As empresas que necessitam de produtividades altas estão usando um sistema conhecido no mercado pelo seu nome em ingês "thermoform/fill/seal" (TFFS), que significa termoformagem/envase/selagem. Os equipamentos do sistema TFFS utilizam duas bobinas de filmes. Geralmente o filme inferior passa pelo processo de termoformagem gerando um "berço" para acondicionamento do produto. O filme superior é utilizado como uma tampa. As máquinas TFFS foram originalmente projetadas para sistemas automáticos de embalagem a vácuo de presuntos, "bacon", salsichas e lingüiças. Com o tempo outros alimentos e até produtos cirúrgicos passaram a ser embalados neste sistema ${ }^{[26,28]}$.

As estruturas termoformadas utilizadas para produtos cárneos são boas barreiras a gases, a fim de minimizar ou evitar por completo o contato do produto com o oxigênio do ar, essas estruturas devem apresentar também boas características de barreira a água e à luz. Os produtos cárneos são sensíveis a reações deteriorativas catalisadas pela luz, as quais podem estar sujeitos durante a sua estocagem e comercialização. As reações de oxidação de lipídios, por exemplo, são altamente sensíveis às radiações de comprimento de onda na região do ultravioleta e do visível, para comprimentos de onda inferior a $470 \mathrm{~nm}^{[19-21,37]}$.

Para os produtos cárneos processados, como a salsicha, a lingüiça e os fatiados, os requisitos de barreira a gases e à luz são maiores, porque a luz irá acelerar a oxidação dos pigmentos e da gordura e, consequentemente, agravar os problemas de descoloração, rancificação e deterioração microbiológica, os quais reduzirão a vida útil do produto ${ }^{[19-21]}$. 


\subsubsection{Propriedades das embalagens plásticas flexíveis}

As principais propriedades avaliadas para as embalagens plásticas flexíveis para produtos cárneos são ${ }^{[\mathbf{1 , 2 1}} \mathbf{2 6 ]}$ :

> Propriedades mecânicas - as propriedades mecânicas estão associadas ao desempenho mecânico dos materiais de embalagens nos equipamentos de conversão, nas máquinas de acondicionamento e frente às inúmeras solicitações dos ambientes de estocagem e distribuição. As principais propriedades mecânicas avaliadas em embalagens flexíveis para produtos cárneos são:

> Propriedades de tração - as propriedades de tração expressam a resistência do material à deformação por alongamento quando submetido à tração, solicitação característica do acondicionamento, dos processos de conversão e do manuseio das embalagens. $O$ ensaio de determinação de propriedades de tração envolve a separação constante de duas garras que prendem as extremidades dos corpos-de-prova, registrando-se ao longo do ensaio a força ou a resistência que o material oferece a deformação ou alongamento. As principais propriedades de tração avaliadas são ${ }^{[1,21]}$ : resistência máxima à tração; resistência à tração na ruptura e porcentagem de alongamento.

> Resistência à delaminação - a resistência à delaminação é uma medida que indica a facilidade de separação de componentes de uma estrutura multicamadas. Os problemas de delaminação têm efeito negativo sobre a aparência do material, podendo também comprometer a integridade, as propriedades de barreira e a resistência mecânica de embalagens flexíveis $^{[21]}$. 
> Resistência ao rasgamento - a resistência ao rasgamento de um material flexível é um parâmetro de resistência mecânica útil para especificação e avaliação da qualidade desses materiais. A resistência ao rasgamento de laminados e filmes flexíveis é definida como a força ou carga, medida diretamente ou por unidade de espessura do corpo de prova, necessária para iniciar o rasgamento ou a propagação de um rasgo em condições específicas de teste. Altos valores de resistência ao rasgamento são geralmente necessários para garantir uma boa maquinabilidade do material ou bom desempenho mecânico da embalagem. Por outro lado, na seleção de materiais para embalagem de fácil abertura ("easy open"), um baixo valor de resistência ao rasgamento é desejável ${ }^{[20,21]}$.

Os materiais de embalagens flexíveis apresentam dois tipos distintos de resistência ao rasgamento: resistência inicial ao rasgamento que é a resistência necessária para iniciar o rasgo e a resistência interna ao rasgamento que é a resistência à propagação do rasgo.

A resistência inicial ao rasgamento de materiais flexíveis e chapas finas pode ser determinada pela metodologia descrita na norma ASTM D1004-66 de 1996 ou pela metodologia descrita na ASTM D2582-87 de 1996 que combina o efeito do início do rasgo a sua propagação, ou seja, a resistência interna ao rasgo, em um só ensaio.

A resistência interna ao rasgo de filmes flexíveis é normalmente definida pela força média, em mili-Newton ou grama-força, requerida para propagar um rasgo em um único filme. Dois métodos são mais conhecidos e empregados para essa determinação: o método descrito na ASTM D1922-93 que utiliza equipamento do tipo Elmendorf e aquele que emprega dinamômetro de tração (máquina universal de ensaios), descrito na ASTM D1938-94 e pela ISO 6383-1:1983 ${ }^{[\mathbf{2 0 , 2 1 ]}}$. 
> Resistência ao impacto do dardo em queda-livre - nesse ensaio determinase a energia que causa falha em filmes flexíveis sob condições específicas de impacto. Esta energia é expressa em termos de peso (massa) de um dardo que cai de uma altura específica, a qual provocará falha em $50 \%$ das embalagens ensaiadas.

O ensaio de resistência ao impacto do dardo em queda-livre é útil para avaliar filmes flexíveis, que, a princípio, deformam no local do impacto e depois rasgam neste local sem, contudo, propagar o rasgo. Podem ser estabelecidas correlações entre os resultados deste ensaio e o desempenho da embalagem durante a sua utiliação. Os valores obtidos dependem muito do processo de fabricação do filme, bem como do tipo e grade de resina utilizada. Esses valores também são influenciados pela qualidade do filme sob ensaio, uniformidade da espessura, presença de impressão e contaminações.

Este ensaio é subdividido em dois métodos, descritos na ASTM D 170991 de 1996. O método A é usado para filmes cuja resistência ao impacto se encontra na faixa entre $50 \mathrm{~g}$ ou menos, até aproximadamente $2 \mathrm{~kg}$. $\mathrm{O}$ método $B$ é usado quando a resistência ao impacto se encontra entre $300 \mathrm{~g}$ até aproximadamente $2 \mathrm{~kg}$. As características do dardo e a altura de queda são diferentes em cada um dos métodos, de modo que, os dados obtidos com um destes métodos não podem ser comparados diretamente com os do outro método ${ }^{[20,21]}$.

> Resistência à perfuração - a resistência à perfuração de embalagens flexíveis é função do material da embalagem monocamada ou dos materiais presentes nas estruturas coextrusadas, da espessura de cada um dos materiais, da presença e grau de orientação, do módulo de elasticidade, da taxa de penetração (velocidade de ensaio), entre outros. 
O ensaio de resistência à perfuração é feito em um dinamômetro de tração (máquina universal de ensaios) conforme método descrito pela norma ASTM F 1306-90 de 2001. O ensaio é realizado utilizando uma célula de carga de $100 \mathrm{~N}$, com velocidade de perfuração de $25 \mathrm{~mm} / \mathrm{min}$. O programa MERLIN associado ao dinamômetro compila os dados e os fornece em uma tabela e um gráfico de extensão $(\mathrm{mm}) \mathrm{X}$ força ou carga aplicada (N) dos pontos que constam nas tabelas ${ }^{[20,21]}$.

> Resistência da termossoldagem à tração - termossoldagem é um processo no qual dois materiais são unidos sob condições que permitam a sua fusão. A termossoldagem se aplica a polímeros termoplásticos e revestimentos termosseláveis. Atualmente, a termossoldagem é a técnica mais utilizada para o fechamento de embalagens plásticas flexíveis.

A qualidade da termossoldagem é função de uma série de fatores dentre os quais destacam-se: o tipo de equipamento utilizado, a forma de aplicação do calor, o perfil do mordente de fechamento e as características físicas e mecânicas do material de embalagem. A resistência da termossoldagem de embalagens flexíveis pode ser determinada por meio de sua resistência à tração, pelo método descrito na ASTM F88-94 de $1995^{[\mathbf{2 0 , 2 1}]}$.

> Propriedades de resistência química: são em geral dadas em função de cada polímero e do contato deste material com o agente químico, esteja ele presente no produto embalado, no processamento ou no ambiente em que $o$ produto é mantido ${ }^{[21]}$.

Propriedades de barreiras: mostram a capacidade de uma embalagem resistir à absorção ou à evaporação de gases e vapores, resistir à permeação de lipídeos e à passagem de luz. Não se deve confundir as propriedades de barreiras com resistência química, que por sua vez é a capacidade de não ser 
afetada (solubilizada, amolecida ou alterada) quando em contato com algum agente químico.

As principais barreiras e permeabilidades estudadas para as embalagens flexíveis de produtos cárneos são ${ }^{[21,26]}$ :

> Taxa de permeabilidade ao vapor dágua;

> Taxa de permeabilidade ao gás oxigênio;

> Taxa de permeabilidade ao gás carbônico;

> Transmissão de Luz;

> Permeabilidade a gordura;

> Permeabilidade a vapores orgânicos.

A quantificação das proriedades de barreiras a gases, vapor d'água ou vapores orgânicos e luz baseiam-se em medições padronizadas. A barreira a gases, por exemplo, é avaliada em termos de taxa de permeabilidade a gases, ou seja, pela quantidade de gás que atravessa uma unidade de área do material de embalagem por unidade de tempo, a uma determinada temperatura, umidade relativa, e sob certo gradiente de pressão parcial do gás de teste ${ }^{[21,26,34]}$.

A propriedade de barreira de uma embalagem está intimamente relacionada a estabilidade química, física, sensorial, microbiológica e biológica dos produtos. O contato do oxigênio com determinados produtos, por exemplo, podem causar uma série de alterações indesejáveis tais como, a rancificação de óleos e gorduras presente nos alimentos. 0 oxigênio pode também oxidar a vitamina $C$, fazendo com que certos produtos venham a perder o seu valor nutricional e oxidar alguns pigmentos e compostos aromáticos, resultando em alterações de cor, aroma e sabor ${ }^{[36,38]}$.

A passagem de gases e vapores através de filmes de embalagens plásticas pode se dar por dois processos ${ }^{[21]}$ : 
> Fluxo através de uma descontinuidade do material, como microporos, microfuros e fraturas, pelos quais gases e vapores fluem livremente;

> Permeação ou efeito solubilização-difusão.

Quanto a estrutura molecular, um polímero, com boas propriedades de barreira, deve possuir as seguintes propriedades ${ }^{[21,39]}$ :

> Alta rigidez da cadeia;

$>$ Alta temperatura de transição vítrea $(\mathrm{Tg})$;

> Inércia em relação ao permeante;

> Certo grau de polaridade, nos casos de permeantes apolares como o oxigênio;

> Possibilidade de auto grau de compactação das cadeias advindo da simetria molecular, grau de cristalização ou orientação;

> Algum grau de ligação ou atração entre as cadeias.

\subsection{Interação produto - embalagem}

As interações produto-embalagem são definidas como uma interrelação entre produto, embalagem e o meio que os cercam, a qual produz efeitos sobre o produto e/ou sobre a embalagem. Estas interações são, na verdade, a transferência de componentes entre o meio, o produto e a embalagem ${ }^{[34]}$.

Os processos de transferência de massa em sistemas de embalagem normalmente referem-se aos fenômenos de permeação, migração e absorção. A permeação é resultado de dois mecanismos básicos: difusão de moléculas através da parede do filme, e absorção/dessorção para o meio interno/externo. Migração é a liberação de componentes da embalagem para o produto embalado ${ }^{[34,36,38]}$. 
A migração de componentes do polímero (por exemplo, monômeros residuais, tintas, aditivos e solventes) para o alimento, foi o primeiro tipo de interação estudada devido aos efeitos sobre a saúde humana.

Posteriormente, a absorção, ou "scalping", de componentes originalmente contidos no produto pelo material da embalagem passou a chamar a atenção. Estes componentes do produto, quando absorvidos pela embalagem podem causar perda de aroma, ou de barreira, alteração nas propriedades mecânicas, resultando em uma redução da qualidade do produto embalado ${ }^{[34,36]}$.

\subsection{Radiação ionizante}

A química das radiações consiste no estudo das reações ou efeitos

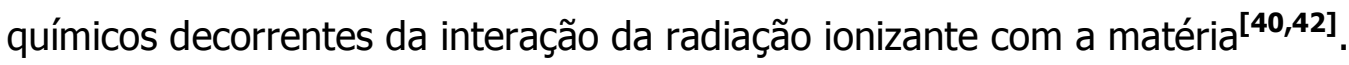

Os termos "radiação ionizante" ou "radiação de energia alta" são usados geralmente para designar radiação eletromagnética, como as radiações emitidas por núcleos radiativos naturais ou artificiais, como os raios gama $(\gamma)$ e as partículas alfa $(\alpha)$ e beta $(\beta)$ ou feixes de partículas aceleradas (elétrons, nêutrons, prótons, dêuterons, produtos de fissão, entre outros) e raios $X$, produzidos no processo de freamento de elétrons de energia alta pela matéria. Estas radiações carregam energia suficiente para ionizar moléculas que apresentam potenciais de ionização entre $10 \mathrm{eV}$ e $15 \mathrm{eV}^{[40-45]}$.

A energia das radiações eletromagnéticas é função da freqüência, ou do comprimento de onda da radiação. São consideradas usualmente, radiação eletromagnética ou radiação de energia alta, aquelas com comprimento de onda acima de $10^{-8} \mathrm{~m}^{[40-45]}$.

Nos processos de interação da energia com a matéria, podem ocorrer três efeitos principais: mudança na estrutura nuclear com a criação de novos 
isótopos ou elementos, deslocamento do núcleo e mudanças químicas como distúrbios da estrutura eletrônica, que levam à ionização, excitação e captura de elétrons ${ }^{[40]}$.

As radiações ionizantes possuem energia de valor superior à energia da ligação química e perdem a sua energia principalmente pela interação com os elétrons orbitais das moléculas localizadas ao longo da sua trajetória, originando estados excitados ou ionizando-as e gerando íons ou radicais livres. A energia de ligação é a quantidade de energia necessária para romper a ligação ${ }^{[15,16]}$.

Radicais livres são átomos ou moléculas que possuem um ou mais elétrons desemparelhados disponíveis para formar ligações químicas. São espécies muito reativas, geralmente, com um tempo de vida muito curto, em virtude da capacidade de gerar outros radicais, por reação com a molécula neutra, sendo o novo radical capaz de repetir o processo, estabelecendo assim, reações muito rápidas em cadeia ${ }^{[14-15]}$.

Uma molécula pode ser ionizada quando ${ }^{[15,16]}$ :

> A quantidade de energia transferida, proveniente da partícula incidente, é menor que o potencial de ionização da molécula, pode ocorrer excitação eletrônica, levando um elétron orbital de seu estado de menor energia (estado fundamental) para um estado de maior energia, tornando a molécula instável e reativa quimicamente;

> A quantidade de energia transferida, proveniente da partícula incidente, é maior que a energia de excitação e de ligação dos elétrons na molécula, sendo a energia suficiente para arrancar um elétron do seu orbital. Assim, um elétron pode ser ejetado, levando consigo uma carga positiva, isto é, ionizando a molécula. 
A ionização ocorre para radiações com comprimento de onda menor que 250 Á e energia maior que $50 \mathrm{eV}$. Comprimentos de onda maiores que $250 \AA ̊$ não provocam ionização mas produzem espécies excitadas ${ }^{[41]}$.

Na química das radiações ionizantes os fótons e as partículas de energia alta não são seletivos, podendo reagir com moléculas que estão ao longo de suas trajetórias, surgindo, estados ionizados e excitados, em alta concentração, particularmente nas fases sólidas e líquidas. Posteriormente as diferentes espécies energéticas produzidas reagem, formando uma mistura complexa de produtos ${ }^{[43,44]}$.

A quantidade de energia absorvida pela matéria em virtude da interação com a radiação ionizante pode ser medida diretamente e o produto da química das radiações é expresso em termos de um valor $\mathrm{G}$, o qual representa o número de moléculas modificadas ou formadas por $100 \mathrm{eV}$ de energia absorvida ${ }^{[15,42]}$.

Os principais mecanismos de interação da radiação ionizante com a matéria são o "efeito fotoelétrico", o "efeito Compton" e a "produção de pares". A predominância de um ou outro, depende da energia do fóton ou da partícula incidente e do número atômico dos elementos químicos que constituem as moléculas da matéria ${ }^{[15,40,46,47]}$.

\subsubsection{Efeito fotoelétrico}

Efeito fotoelétrico é o processo pelo qual os fótons ao serem absorvidos pelos átomos e moléculas do material absorvedor, mudam os estados eletrônicos desses átomos e moléculas. Nesse processo o fóton incidente transfere toda a sua energia para o elétron ligado ao átomo, provocando sua emissão. Nesse tipo de interação toda a energia do fóton $\left(E_{0}\right)$ é transferida para um único elétron atômico que é ejetado do átomo com uma energia $\left(E_{C}\right)$ igual a diferença entre a energia 
do fóton e a energia de ligação $\left(E_{L}\right)$ do elétron no átomo, ou seja, parte da energia é utilizada para "liberar" o elétron (ionização) e o restante é carregado pelo elétron como energia cinética. De acordo com a energia do fóton incidente, este pode ser absorvido por elétrons de diferentes camadas de energia.

A probabilidade da ocorrência do efeito fotoelétrico depende do número atômico do átomo no qual o efeito é observado, ou seja, quanto maior o número atômico, maior a probabilidade ${ }^{[15,40]}$.

O efeito fotoelétrico é mais significativo em energias baixas e em materiais pesados, nos quais a probabilidade da ocorrência é relativamente grande, mesmo para fótons de energias altas, enquanto para os materiais leves (número atômico pequeno) a ocorrência limita-se aos fótons de energias baixas $^{[15,40,46]}$.

Na FIG. 9 é apresentada uma representação do efeito fotoelétrico.

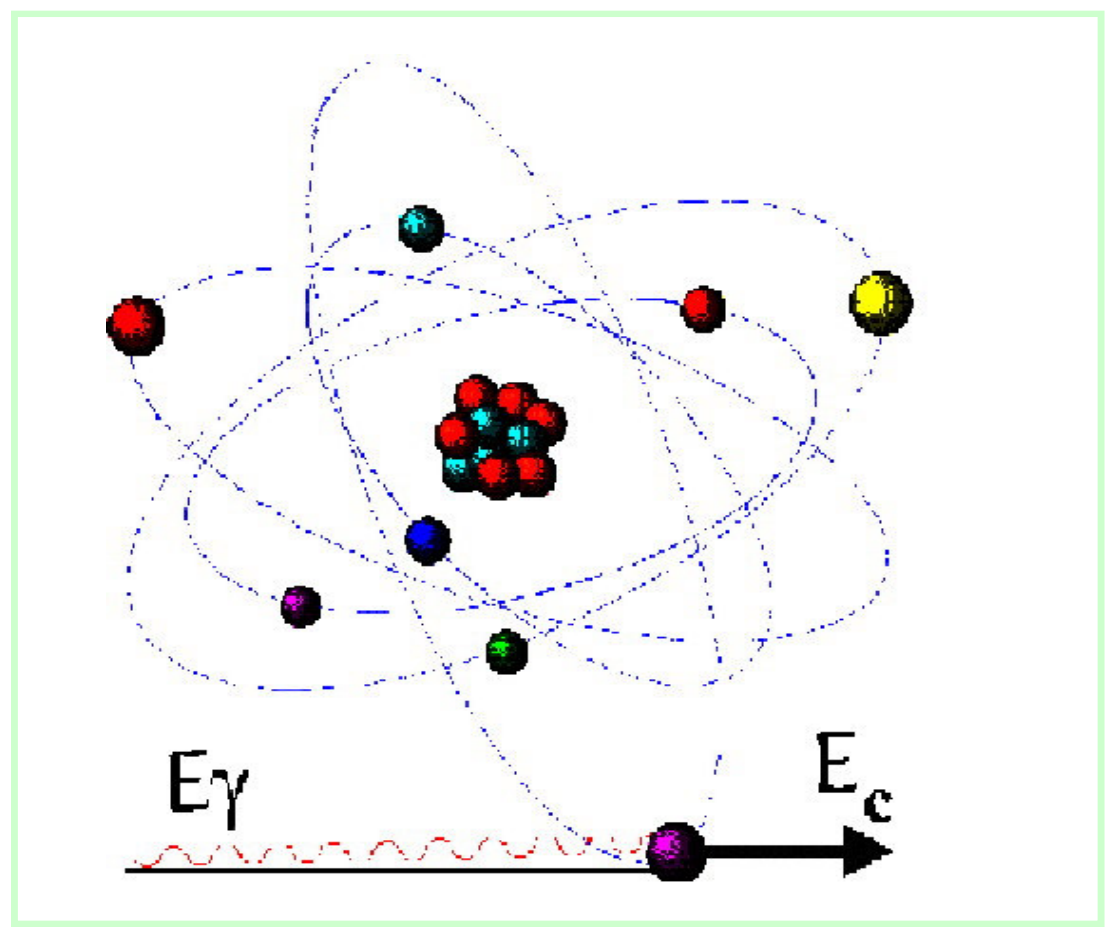

FIGURA 9 - Representação do efeito fotoelétrico 


\subsubsection{Efeito Compton}

No efeito Compton, o fóton incidente interage com os elétrons de níveis energéticos internos (órbita K, por exemplo). Neste caso produz-se uma dispersão elástica nos átomos e moléculas do material absorvedor, gerando elétrons de retrocesso ("recoil electrons") e fótons secundários ${ }^{[15,40,46]}$.

O efeito Compton ocorre quando um fóton interage com um elétron que está fracamente ligado ou livre, tal que o elétrons é acelerado e o fóton defletido com energia menor. A energia e o momento do fóton incidente são divididos entre o fóton espalhado e o elétron recuado ("recoil electrons").

Na FIG.10 é apresentada uma representação do efeito Compton.

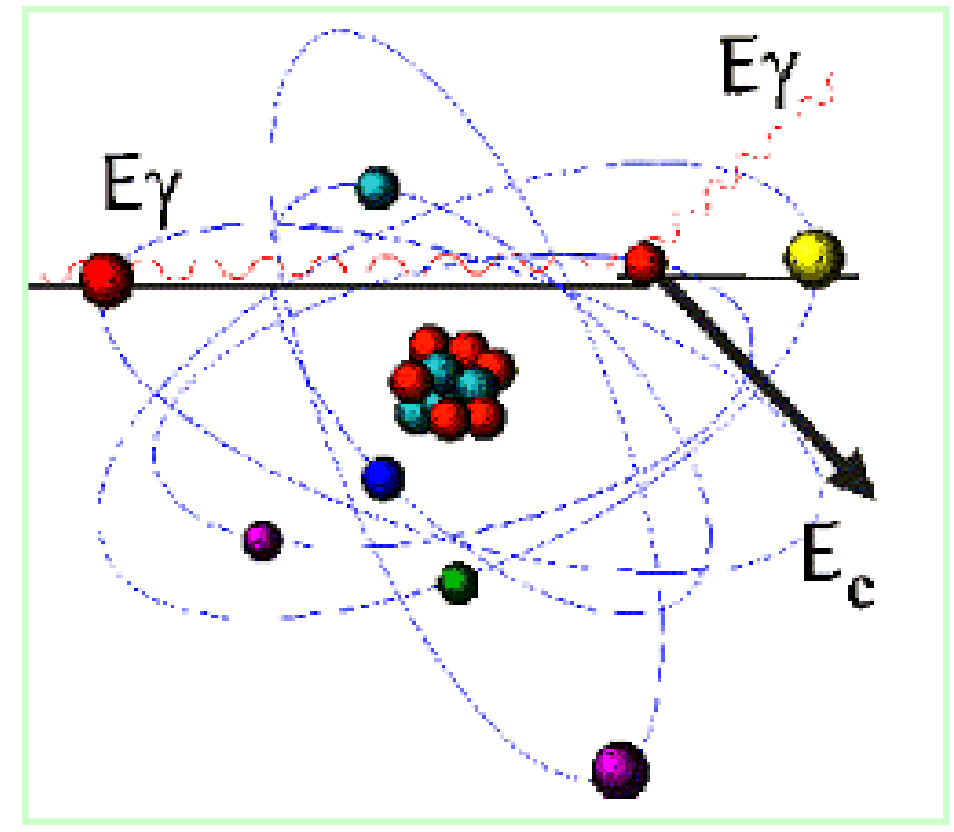

FIGURA 10 - Representação do efeito Compton

A probabilidade de ocorrência do efeito Compton é proporcional ao número atômico do absorvedor e varia com o inverso da energia do fóton. Ele é o principal responsável pelas interações da radiação gama com a matéria no 
intervalo de energia que vai desde algumas centenas de keV até aproximadamente $6 \mathrm{MeV}^{[\mathbf{1 5}, \mathbf{4 0 , 4 6 ]}}$.

\subsubsection{Produção de pares}

Na produção de pares, um fóton de alta energia perde toda a sua energia em uma colisão com o núcleo dos átomos e moléculas do material absorvedor e ao ser absorvido pelo núcleo gera um par elétron-pósitron com uma certa energia cinética ${ }^{[\mathbf{1 5 , 4 0 , 4 7 ]}}$.

O pósitron é uma partícula que possui todas as propriedades do elétron, exceto o sinal de sua carga (e o de seu momento magnético) que é o oposto ao do elétron ${ }^{[\mathbf{1 5 , 4 0 ]}}$.

Na produção de pares o pósitron é produzido com uma energia cinética em média maior que a do elétron porque a interação coulombiana do par com o núcleo carregado positivamente causa uma aceleração no pósitron e uma desaceleração no elétron. Este mecanismo de interação da radiação ionizante com a matéria ocorre para fótons com energia maior que $1,02 \mathrm{MeV}^{[\mathbf{4 0 , 4 6 , 4 7 ]}}$.

Na FIG.11 é apresentada uma representação da produção de pares.

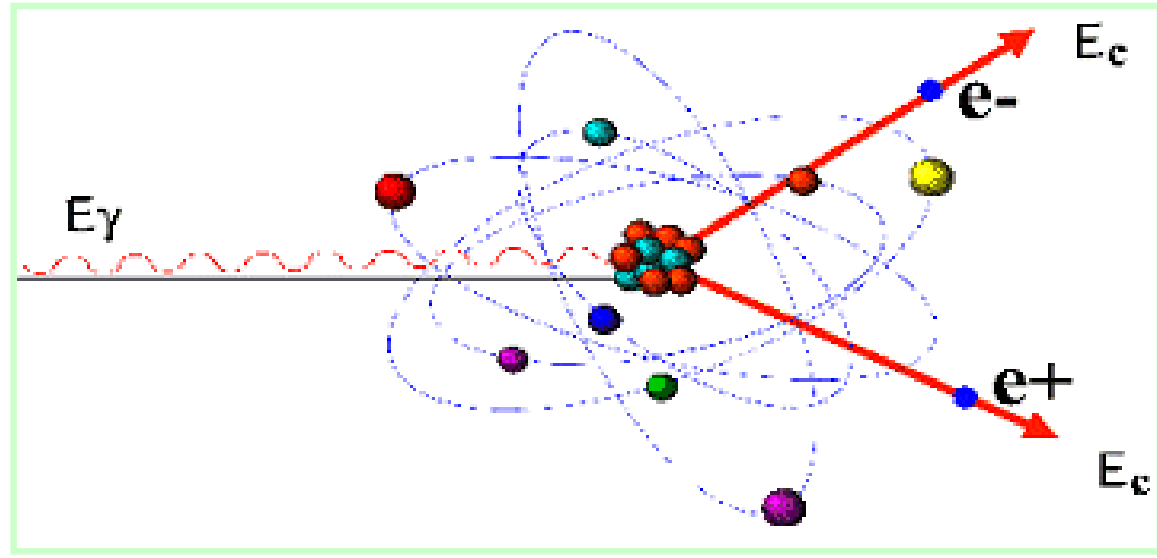

FIGURA 11 - Representação da produção de pares 


\subsubsection{Radiação ionizante de interesse para a química de polímeros}

Sob o ponto de vista prático, as radiações de interesse para a química de polímeros são limitadas aos raios " $X$ ", " $\beta$ ", aos nêutrons, e as radiações " $\gamma$ ", e aos feixes de elétrons, que foram utilizados neste trabalho ${ }^{[\mathbf{1 5 , 4 4 - 4 6 ]}}$.

\subsubsection{Raios gama}

Os raios gama são radiações eletromagnéticas emitidas pelo núcleo de isótopos radioativos naturais e artificiais. São as radiações mais usadas na química de polímeros, tanto em pesquisas como em instalações comerciais ${ }^{[45]}$.

$\mathrm{O}$ emissor gama mais utilizado é o ${ }^{60} \mathrm{Co}$, um radioisótopo com meia-vida de 5,27 anos, produzido pela ativação do ${ }^{59} \mathrm{Co}$ em reatores nucleares. Emite dois raios gama, sendo um com energia de 1,17 MeV e o outro de 1,33 MeV. Têm forte poder de penetração e a sua intensidade é reduzida a $1 / 10$ do valor inicial, após passar por 43,2 cm de água ou material similar ${ }^{[43-46]}$.

Outro emissor de grande interêsse é o radioisótopo ${ }^{137} \mathrm{Cs}$, que tem uma meia-vida de 30,14 anos (muito maior que a do ${ }^{60} \mathrm{Co}$ ) e emite raios gama com 0,66 MeV de energia. Esta radiação tem poder de penetração muito menor que aquela do ${ }^{60} \mathrm{Co}$, requer uma blindagem menos severa e pode ser usada facilmente para irradiar substâncias em recipientes de aço ${ }^{[43-46]}$.

Os raios gama perdem e transferem sua energia pelos mecanismos do "efeito fotoelétrico", "efeito Compton" e "produção de pares". Quando os raios gama possuem uma quantidade de energia entre 0,5 MeV e $2 \mathrm{MeV}$ a interação com a matéria, com exceção dos elementos pesados, ocorre, preferencialmente, pelo "efeito Compton", o qual é o mecanismo mais importante de perda e transferência de energia para os compostos orgânicos e, conseqüentemente, para os sistemas poliméricos ${ }^{[45-47]}$. 


\subsubsection{Feixe de elétrons}

O feixe de elétrons ("electron beam") é uma radiação ionizante gerada em máquinas industriais, denominadas de aceleradores de elétrons. Quando esses elétrons dentro de uma faixa de energia que vai de alguns quilos de eletronvolts (keV) até milhões de eletronvolts (MeV) são absorvidos pela matéria e elétrons secundários são produzidos como resultado dos processos de interação.

Os elétrons acelerados perdem energia por interações de Coulomb com os átomos ou moléculas presentes no material que está sendo irradiado. Então, resulta na formação de radicais livres, íons, elétrons e átomos ou moléculas no estado excitado ${ }^{[48,49]}$.

Os elétrons gerados em aceleradores possuem energia suficiente para romper qualquer tipo de ligação química e iniciar uma reação de polimerização. Porém, a penetração do elétron na matéria é função da sua energia ${ }^{[48,49]}$.

A absorção de energia proveniente da radiação ionizante produzida por um feixe de elétrons acelerados pelo meio absorvedor ocorre devido às interações da radiação com a nuvem eletrônica do meio. Se os elétrons do feixe não possuirem energia suficiente não atingem o núcleo, interagem somente com a eletrosfera. Nesse caso a nuvem eletrônica age como um anteparo (blindagem), impedindo a aproximação dos elétrons do feixe junto ao núcleo ${ }^{[27]}$. Se a energia de aceleração for suficiente, o feixe de elétrons pode atravessar lâminas metálicas e fios finos, camadas de tintas ou vernizes contendo materiais opacos, embalagens plásticas mono ou multicamadas, carnes e produtos cárneos processados, entre outros.

Na FIG. 12 é mostrado o poder de penetração dos elétrons em função da sua energia. 


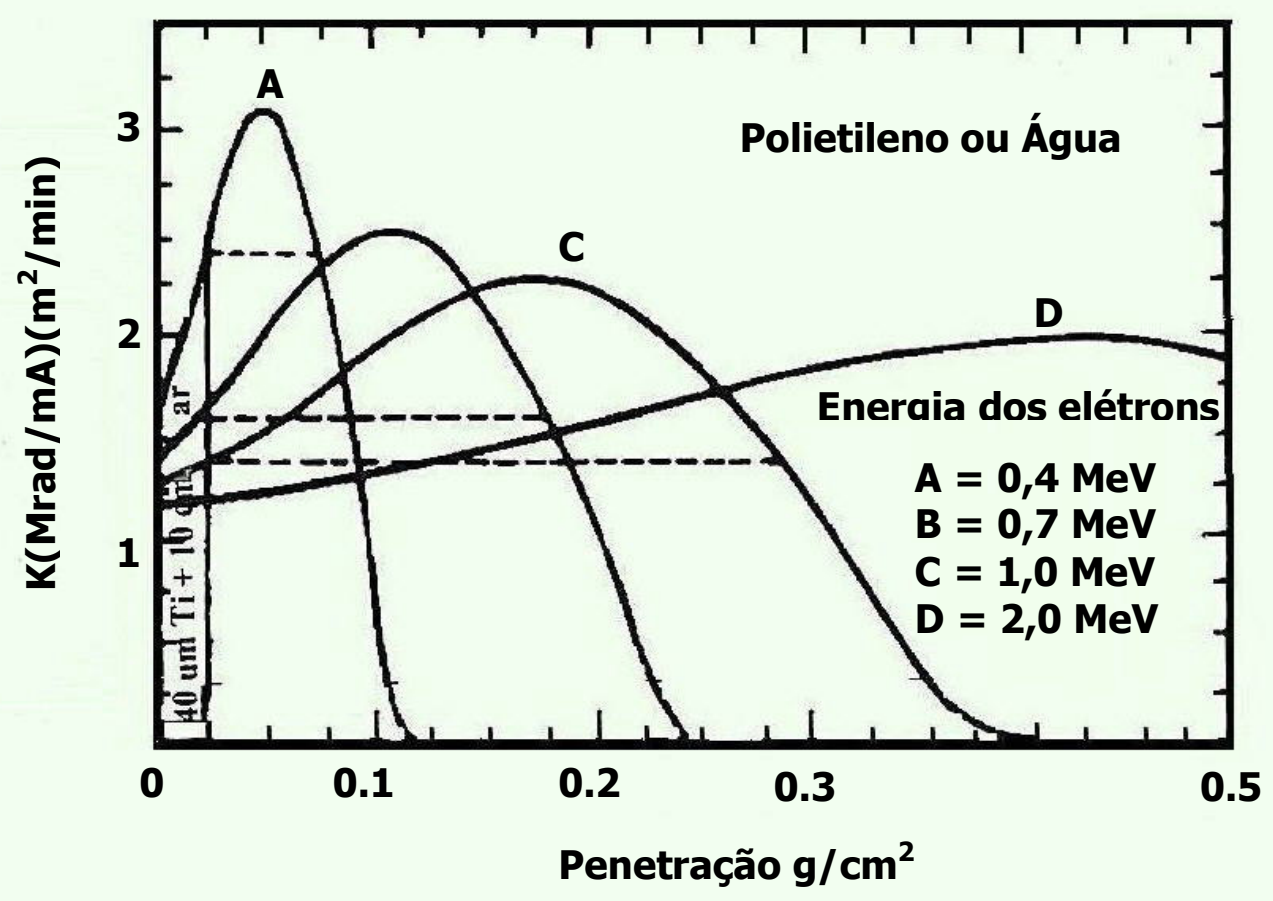

FIGURA 12 - Penetração do feixe de elétrons em função da energia em MeV

\subsubsection{Irradiadores gama e aceleradores de elétrons}

Os processos de irradiação economicamente viáveis para aplicação industrial, em alimentos, modificação de polímeros e materiais plásticos de embalagens, baseiam-se na radiação gama obtida pela desintegração do radionuclídeo ${ }^{60} \mathrm{Co}$ (fontes gama de ${ }^{60} \mathrm{Co}$ ) e radiação proveniente de feixe de elétrons ("electron beam"), gerados em dispositivos aceleradores de partículas ("aceleradores de elétrons") ${ }^{[\mathbf{1 2}, \mathbf{1 5}]}$.

\subsubsection{Irradiadores gama}

As intalações que utilizam fontes gama de ${ }^{60} \mathrm{Co}$, denominadas tecnicamente "irradiadores gama", consistem de pastilhas ou tarugos do radionuclídeo ${ }^{60} \mathrm{Co}$ encapsulados em "zircaloy". Posteriormente são colocados em 
arranjos na forma de lápis de aço inoxidável, sendo selados e dispostos em geometria tal, de maneira a permitir que o material receba uma dose o mais homogênea possível. Além disso, o encapsulamento das pastilhas frea a partícula beta e permite o aproveitamento total dos fótons gama emitidos pelo ${ }^{60} \mathrm{Co}^{[12, \mathbf{1 5}]}$.

De acordo com a Agência Internacional de Energia Atômica (AIEA), os irradiadores gama são sub-divididos em categorias, em função dos aspectos de segurança, acessibilidade e blindagem ${ }^{[48]}$.

Existem quatro tipos ou categorias de irradiadores gama a saber :

Categoria I - irradiador comercialmente conhecido como "Gammacelr". Neste irradiador a fonte selada é completamente encapsulada e blindada em um contêiner seco, construído de materiais sólidos. $\mathrm{O}$ acesso à fonte radioativa selada ou à região de irradiação não é fisicamente possível, em função da sua configuração (FIG.13).

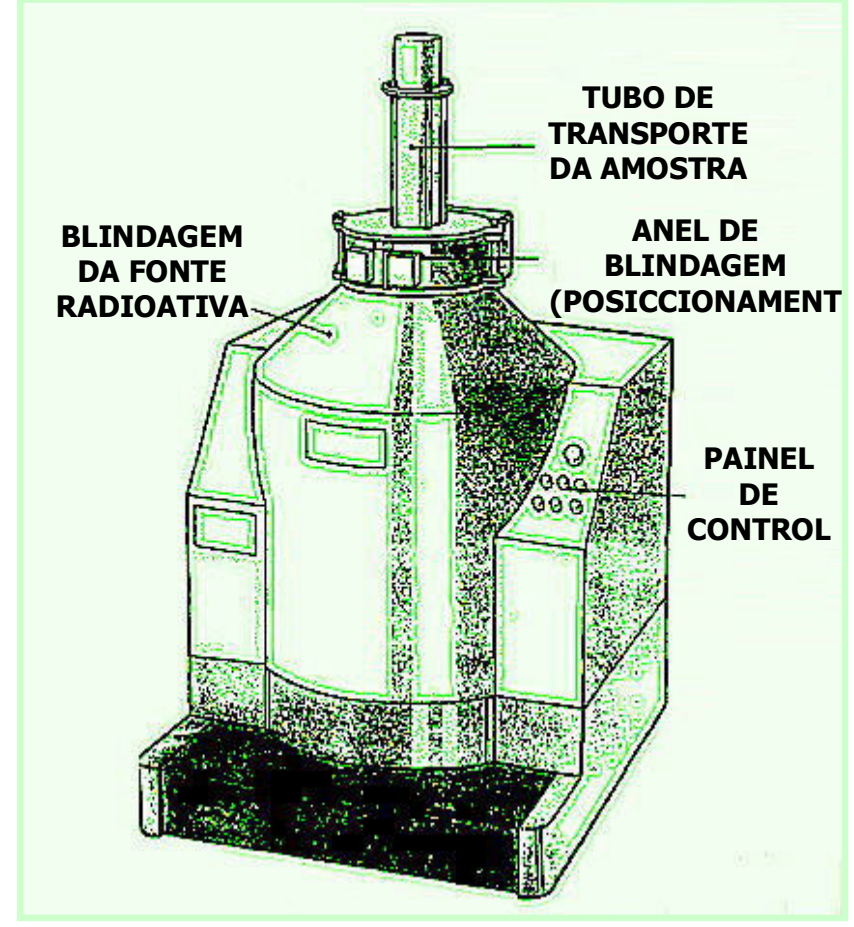

FIGURA 13 - Irradiador gama de cobalto-60 tipo Gammacell, categoria I pela AIEA 
> Categoria II - é um irradiador do tipo panorâmico, de fonte anular e completamente selada em um contêiner construído em materiais sólidos e totalmente blindada, quando não está sendo utilizada. No momento da irradiação a fonte é retirada da blindagem por um sistema automático de elevação especial e mantida dentro de um compartimento fechado e inacessível. A seguir é posicionada ao nível e direção do material a ser irradiado. Ao término da irradiação, o sistema de elevação especial é novamente acionado e a fonte é recolocada no interior da blindagem (FIG.14).

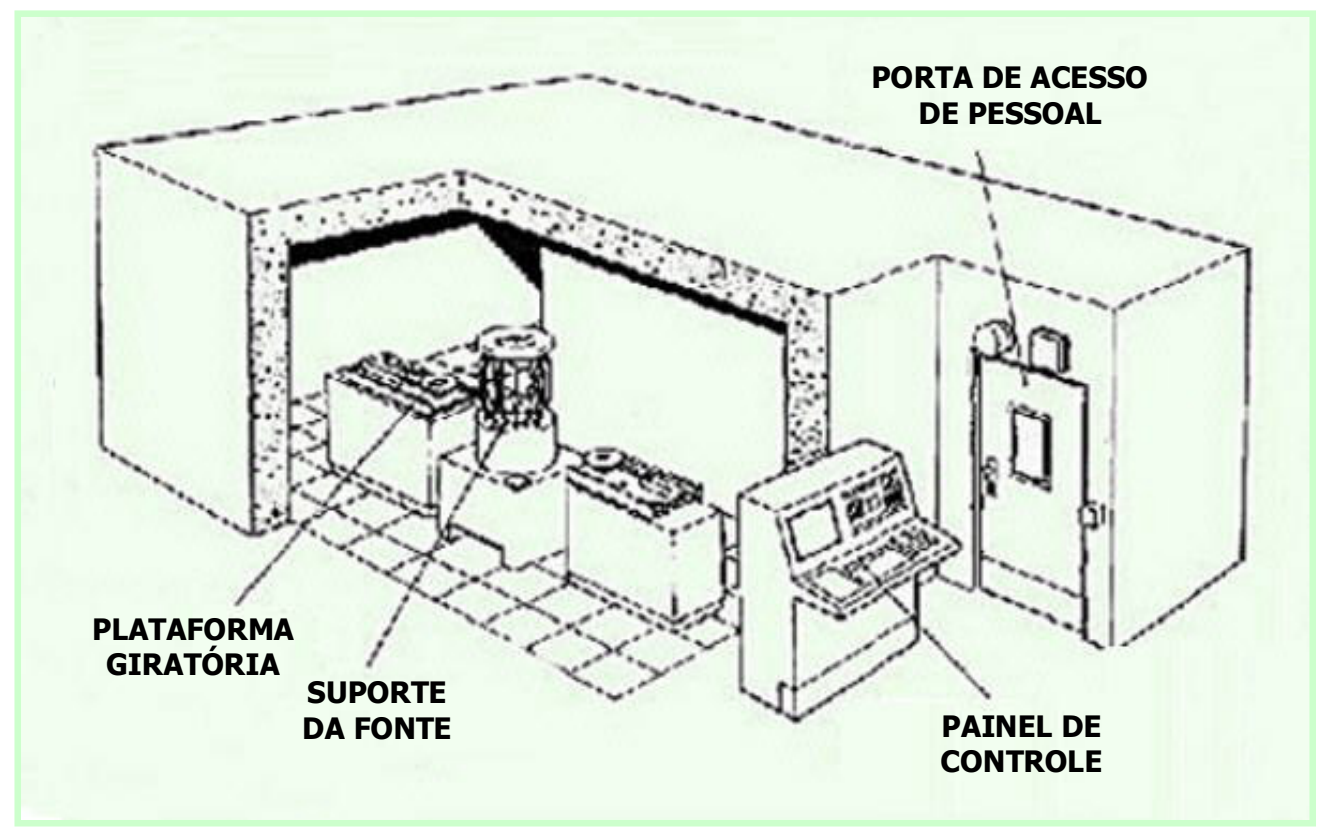

FIGURA 14 - Irradiador gama de cobalto-60 tipo panorâmico, categoria II pela AIEA 
> Categoria III - a fonte selada é armazenada em uma piscina de estocagem, constantemente blindada por água deionizada. $\mathrm{O}$ acesso a fonte é fisicamente restrito pelo projeto de construção(FIG. 15).

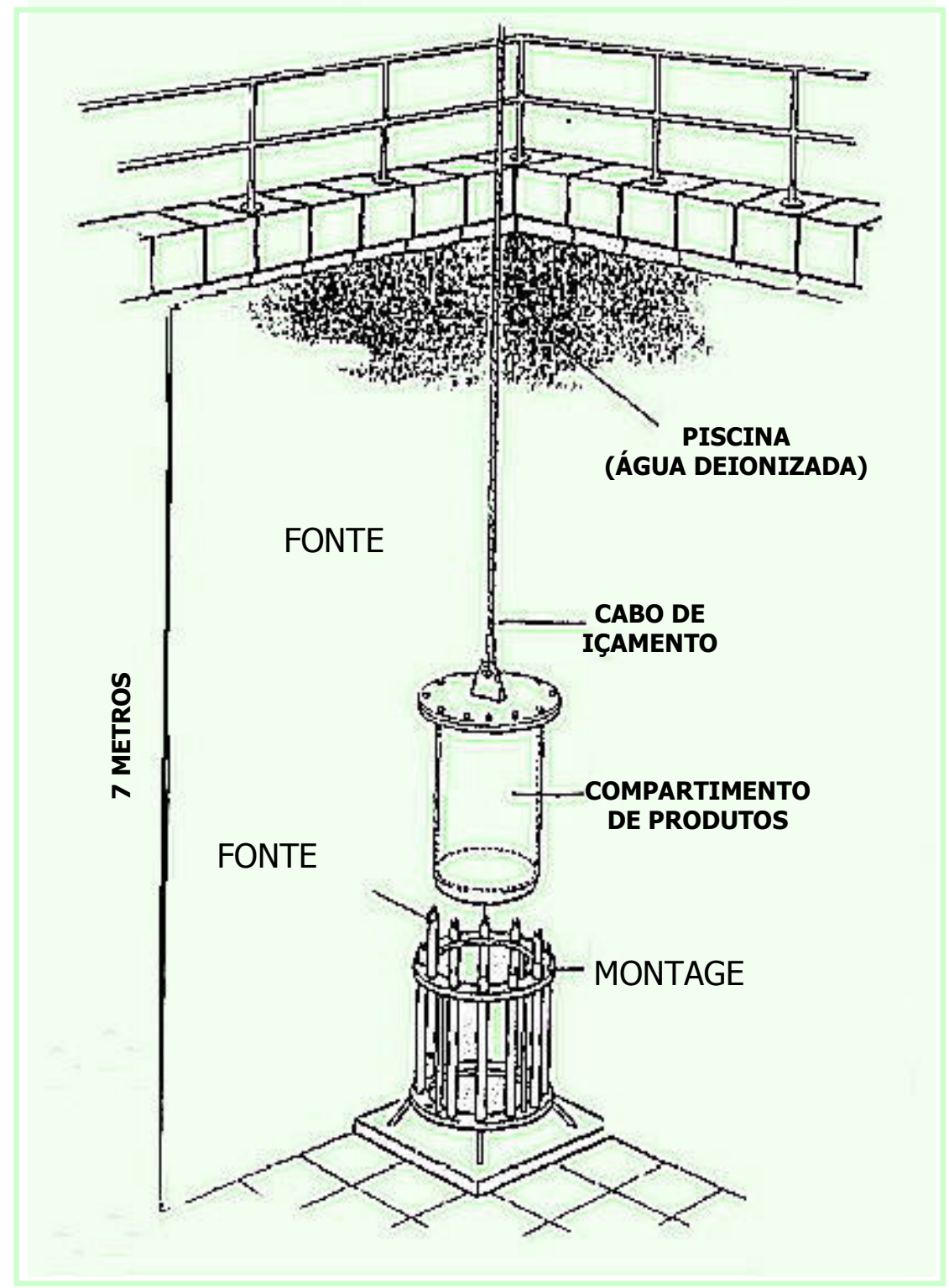

FIGURA 15 - Irradiador gama de cobalto-60, categoria III pela AIEA 
Categoria IV - a fonte selada é armazenada em uma piscina de estocagem, constantemente blindada com água deionizada. Assim, a fonte é completamente blindada quando não está sendo utilizada e o compartimento de irradiação é mantido inascessível durante o uso do equipamento, por meio do sistema de segurança e intertravamento (FIG.16).

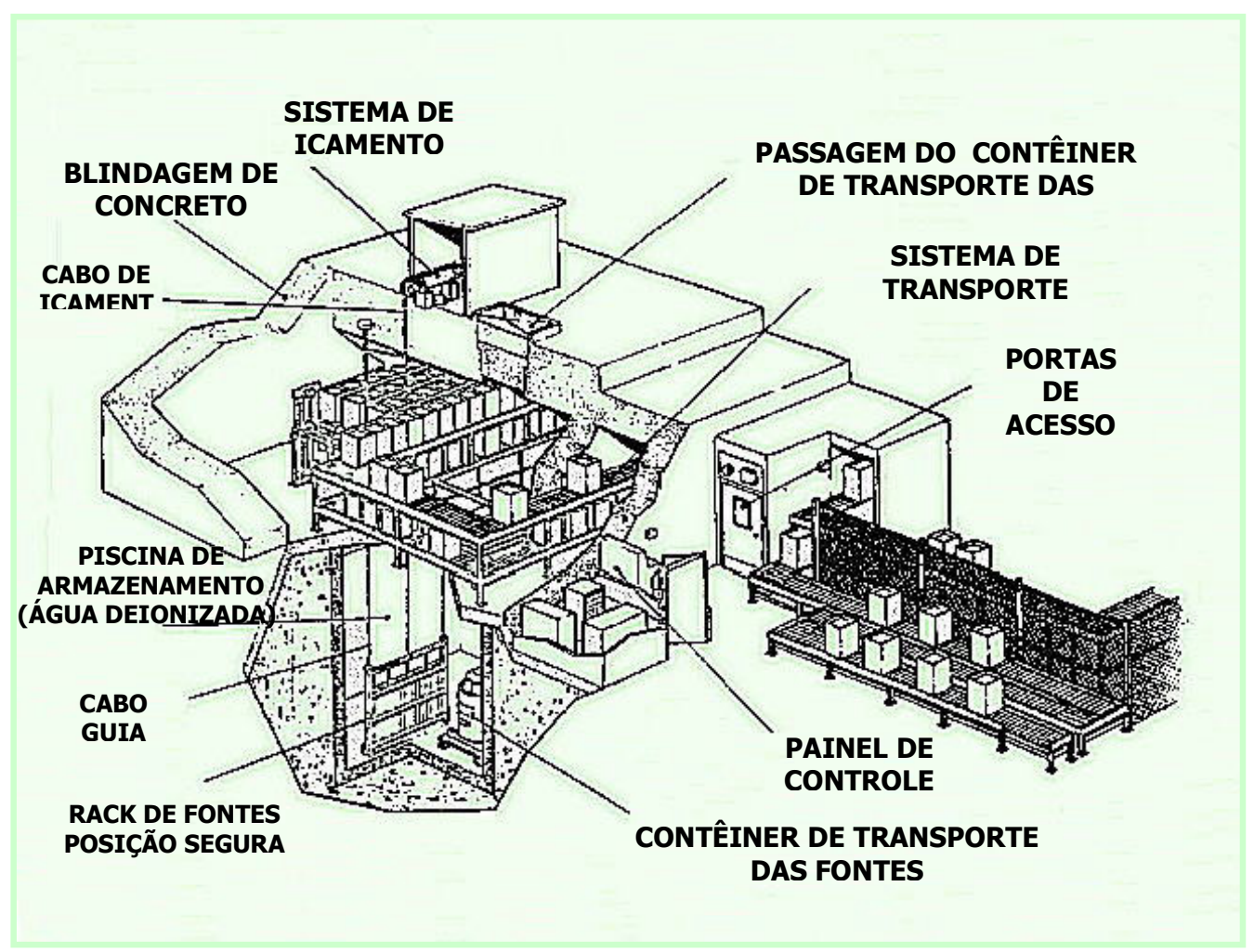

FIGURA 16 - Irradiador gama de cobalto-60, categoria IV pela AIEA 


\subsubsection{Aceleradores de elétrons}

O acelerador de elétrons é um equipamento que aplica forças a partículas carregadas por meio de alguma combinação de campos elétricos e magnético, gerando íons com velocidade e energia cinética altas. Quando se estabelece um potencial de alta tensão entre o cátodo e o ânodo, no vácuo, o cátodo emite o feixe ("chuveiro") de elétrons ${ }^{[12,50]}$.

Os principais componentes e subsistemas de um acelerador de elétrons são a fonte de alta tensão, o tubo acelerador com seu sistema de vácuo, o canhão de elétrons, sistemas de radiofrequência, câmara de ionização, painel de controle e um sistema de segurança que inclui a blindagem da radiação ${ }^{[12,48,50]}$.

Os aceleradores de elétrons podem gerar além de elétrons acelerados, os raios-X de energia alta, ou seja, podem gerar partículas leves (com baixo poder de penetração no material) e fotônicas (com alto poder de penetração no material $)^{[12,48,50]}$.

Os aceleradores industriais de elétrons são classificados de acordo com a energia do feixe produzido. Temos então, aceleradores de baixa energia, entre $150 \mathrm{keV}$ e 2,0 MeV de energia, de média energia, entre 2,5 e 8,0 MeV e de alta energia, aceleradores acima de $9 \mathrm{MeV}^{[\mathbf{1 2}]}$.

Além da energia, outros parâmetros importantes em um acelerador de elétrons é a potência e a corrente do feixe. A potência de um acelerador é um produto da energia do feixe de elétrons e da corrente do feixe, por exemplo, um acelerador com 5,0 MeV de energia e $30 \mathrm{~mA}$ de corrente terá uma potência de $150 \mathrm{~kW}^{[12]}$.

Os aceleradores industriais de elétrons podem também ser classificados de acordo com a forma de geração e aceleração dos elétrons. Segundo esta classificação os cinco principais tipos de aceleradores são ${ }^{[12,48]}$ : 
> Eletrostáticos (Corrente Contínua, CC);

$>$ Eletrodinâmico (CC);

$>$ Radio freqüência (RF);

$>$ Lineares ("LINACS");

> Lineares de indução magnética ( "LINACs");

> Máquinas de ondas contínuas.

Em geral, os aceleradores CC são caracterizados pela alta potência de saída e alta eficiência, enquanto os sistemas "LINAC" são tipicamente muito mais compactos e podem gerar feixe de alta energia, porém, são consideravelmente menos eficientes. Similarmente, as máquinas de ondas contínuas podem ser moderadamente compactas e podem alcançar alta energia de feixe $e^{[\mathbf{1 2}, \mathbf{5 0 ]}}$.

Nos aceleradores os feixes de elétrons podem ser produzidos por um processo direto ou indireto. No processo direto, os elétrons são produzidos em um cátodo aquecido e mantido em uma região de potencial mais elevado. Esses elétrons são acelerados então por uma diferença de potencial aplicada entre o cátodo e o ânodo (a parede externa da janela do feixe). Assim, os elétrons adquirem energia suficiente para atravessar a janela de saída que, em geral, é constituída de uma folha fina de titânio com espessuras entre 20 e $40 \mu \mathrm{m}$. Esse metal apresenta resistência mecânica suficiente para suportar a pressão atmosférica do exterior. Toda a região de produção e aceleração dos elétrons deve ser mantida em alto vácuo para permitir que a focalização e a aceleração do feixe em direção à janela do feixe sejam adequadas ${ }^{[12,48-50]}$.

Basicamente, o princípio de funcionamento de um acelerador de elétrons industrial pelo processo direto se assemelha ao funcionamento do tubo de imagem de uma televisão, onde os elétrons são gerados por efeito termoelétrico e acelerados no vácuo em um campo elétrico de alta intensidade até atingir o alvo ou produto. A diferença básica entre os dois está na intensidade do campo elétrico, nos aceleradores industriais o campo elétrico pode chegar até 10.000.000 volts enquanto na televisão a intensidade é da ordem de 25.000 volts. 
Os valores elevados do campo elétrico dos aceleradores, responsáveis pela energia adquirida pelos elétrons faz com atravessem uma janela metálica com espessura da ordem de até $40 \mu \mathrm{m}$ e interajam com 0 material a ser processado ${ }^{[12,48,50,51]}$.

Na FIG.17 é ilustrado o princípio de funcionamento de um acelerador de elétrons pelo processo direto ${ }^{[51]}$.

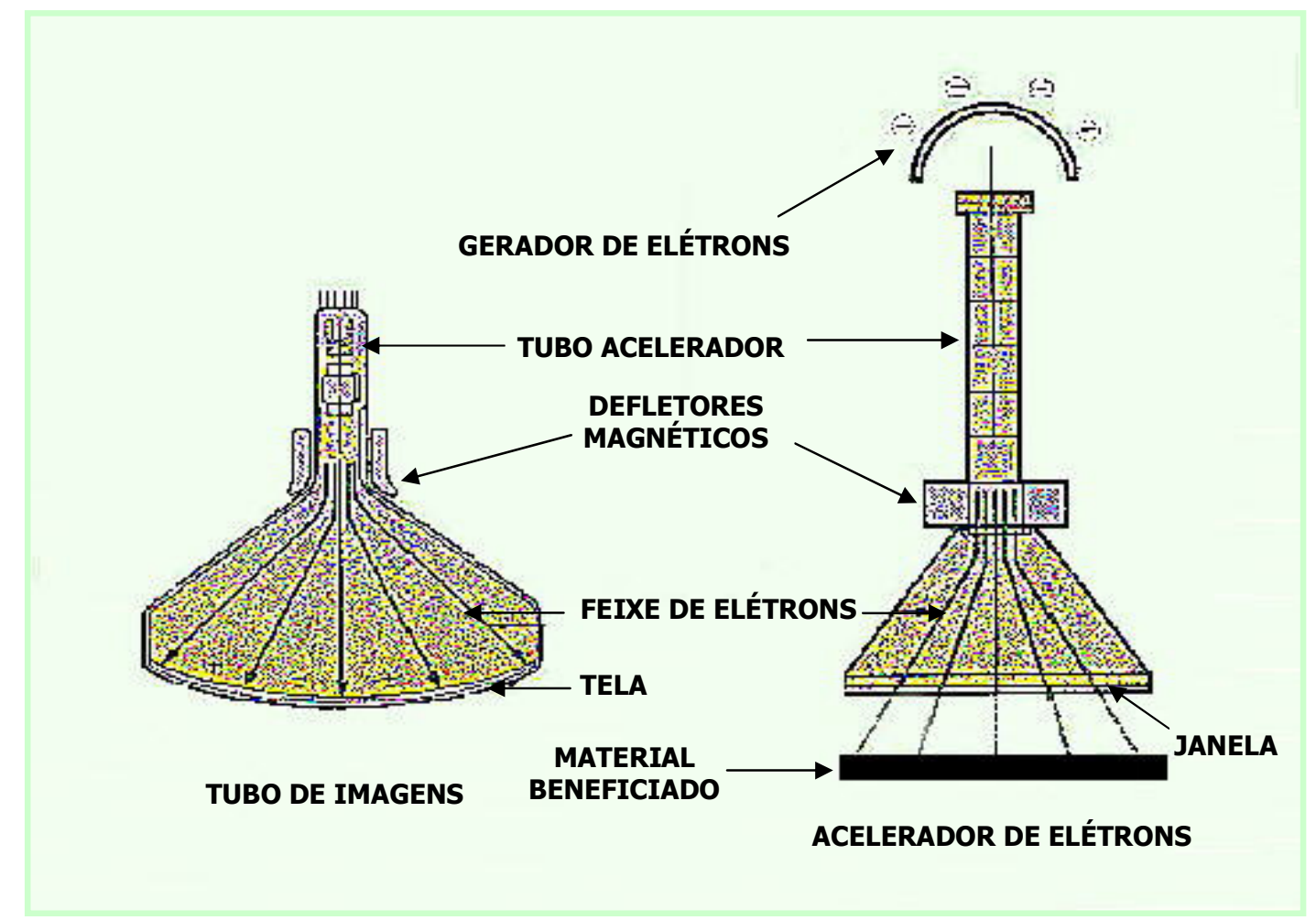

FIGURA 17 - Ilustração do princípio de funcionamento de um acelerador de elétrons pelo processo direto.

Este tipo de acelerador, fornece elétrons acelerados com energia, entre $3500 \mathrm{keV}$ e $5 \mathrm{MeV}$, possuindo um poder de penetração na água de aproximadamente $3 \mathrm{~mm}$ para elétrons com $1 \mathrm{MeV}$ de energia ${ }^{[27,50]}$.

Na produção de um feixe de elétrons por meio de um processo indireto, os elétrons provenientes de um emissor termoiônico são injetados em pequenos pulsos através de cavidades ressonantes a vácuo, que servem como guia de onda, 
produzindo, desta maneira, uma radiação eletromagnética interna de rádio freqüência (RF). Os elétrons absorvem a energia do campo eletromagnético oscilante na cavidade. Com este tipo de equipamento é possível, variando o número de cavidades e o campo gerado nelas, acelerar elétrons com energias entre 10 e $30 \mathrm{MeV}$. Em razão da maior energia, o feixe de elétrons produzido pode penetrar cerca de $50 \mathrm{~mm}$ na água, desde que o equilíbrio eletrônico seja alcançado, ou seja, os elétrons acelerados neste processo tem um poder de penetração e alcança uma profundidade muito maior do que a alcançada pelo feixe de elétrons produzidos pelo processo direto ${ }^{[12,27,50]}$.

O material a ser irradiado por um feixe de elétrons, produzido tanto pelo processo direto como indireto, é, geralmente, transportado sob o feixe de elétrons emitidos pelo canhão de elétrons, dentro de uma câmara de irradiação, com atmosfera desejada para a irradiação ${ }^{[12]}$.

Em razão da energia alta dos elétrons acelerados em um acelerador de elétrons, o tempo de interação entre os elétrons do feixe e o material é muito pequeno (cerca de $10^{-18} \mathrm{~s}$ ). A energia transferida pelos elétrons incidentes é distribuída aleatoriamente, no material, via colisões não elásticas, sendo que a energia transferida para um componente particular do material a ser irradiado depende da fração de elétrons orbitais deste componente particular do material

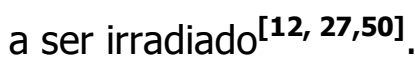

Os espaços de tempo muito curto em que ocorrem as irradiações é uma das grandes vantagens dos aceleradores de elétrons sobre os irradiadores gama industriais. Porém, existem desvantagens ou limitações, como o custo alto de um acelerador de elétrons industrial, comparado com um irradiador gama industrial adequado para a mesma aplicação, o poder de penetração e a flexibilidade deste último, a qual permite diversidade de aplicações ${ }^{[\mathbf{1 2 , 1 5}]}$. 


\subsection{A radiação ionizante e a preservação de alimentos}

As pesquisas sobre tratamento e preservação de produtos alimentícios por radiação ionizante teve início há mais de 100 anos atrás, logo após Becquerel ter descoberto a radioatividade em 1895. Já nos primeiros anos de 1900 eram emitidas patentes nos Estados Unidos e na Inglaterra que tratavam especificamente da destruição de microorganismos em alimentos por radiação. 0 interesse nessa técnica intensificou-se durante a Segunda Guerra Mundial. Entretanto, a falta de um controle adequado do processo causou uma superexposição da maior parte dos produtos, acarretando mudanças indesejáveis nos mesmos, inclusive no sabor ${ }^{[9-12]}$.

Logo após a Segunda Guerra Mundial, quando fontes de radiação mais adequadas tornaram-se disponíveis, deu-se início à era moderna da pesquisa de aplicações da radiação ionizante em alimentos. Instituições pioneiras, como o Massachusetts Institute Technology (MIT) dos EUA e os laboratórios Natick das Forças Armadas Norte-Americanas iniciaram estudos detalhados sobre irradiação de alimentos, o que levou a uma maior otimização do processo para satisfazer exigências de produtos individuais e o propósito do tratamento ${ }^{[9-12]}$.

No final do século passado houve um interesse mundial no processamento de alimentos por radiação e muitos dos efeitos benéficos da irradiação em doses baixas foram reconhecidos. Estes incluem a capacidade de inibir a germinação pós-colheita em batatas e cebolas, a desinfestação de frutas, legumes, vegetais, cereais, especiarias e grãos, a inibição do brotamento em bulbos e tubérculos, o retardo da maturação de frutas e legumes, a eliminação de parasitas (cisticercose e triquinose - vermes), a redução da carga microbiana (fungos, bactérias e leveduras) e a eliminação de patógenos de alimentos frescos e condimentos ${ }^{[9-12]}$.

Grandes avanços foram alcançados no desenvolvimento de equipamentos de irradição, tanto aqueles que utilizam a radiação gama emitida 
por núcleos radiativos, proveniente pincipalmente dos radioisótopos ${ }^{60} \mathrm{Co}$ e ${ }^{137} \mathrm{Cs}$, como a gerada por partículas reativas de energia alta, especialmente os dispositivos geradores de elétrons acelerados, denominado feixe de elétrons, e a radiação produzida, raios $\mathrm{X}^{[\mathbf{9 - 1 2}]}$.

Enquanto os radioisótopos ${ }^{60} \mathrm{Co}$ e ${ }^{137} \mathrm{Cs}$ foram disponibilizados por meio do bombardeamento de cobalto natural com nêutrons ou como subprodutos de reatores nucleares, respectivamente, aparelhos de raios $\mathrm{X}$ e aceleradores de elétrons também foram desenvolvidos para o processamento por radiação. As pesquisas sobre aspectos básicos do processamento de alimentos por radiação também geraram informações detalhadas sobre a sensibildade à radiação em microorganismos, parasitas e insetos de origem alimentar e também sobre as mudanças bioquímicas associadas ${ }^{[\mathbf{9 - 1 2}]}$.

Em 1969, os avanços alcançados no processamento de alimentos por radiação e a preocupação com uma crescente incidência de doenças causadas por alimentos contaminados além de perdas importantes na produção mundial de alimentos pela ação de pragas, insetos, bactérias, fungos, enzimas e roedores, levaram a Organização Mundial da Saúde (OMS), a Organização das Nações Unidas para a Agricultura e Alimentação (FAO) e a Agência Internacional de Energia Nuclear (AIEA) a estabelecer um Grupo Consultivo Internacional Sobre Irradiação de Alimentos e a criação de um Comitê Misto de Especialistas Sobre Alimentos Irradiados (CMEAI) para avaliar e assessorar as atividades globais de irradiação de alimentos ${ }^{[\mathbf{9 - 1 2}]}$.

Em 1980, após avaliar as informações existentes até então, o Comitê concluiu que a irradiação de qualquer alimento com uma dose total média de até 10 kGy era segura no tocante aos aspectos toxicológicos, nutricionais e microbiológicos. Essa conclusão levou a Comissão do Codex Alimentarius, que é um órgão conjunto da FAO e da OMS, a aprovar, em 1983, uma norma mundial para os alimentos irradiados. Essa aprovação, por sua vez, impulsionou as autoridades de vigilância sanitária e segurança alimentar de 37 países a buscar 
soluções nos processos de preservação de alimentos por radiação, com consequente aprovação da irradiação de 40 tipos distintos de alimentos, englobando especiarias, grãos, carnes frescas "in natura" e seus derivados, frutas e legumes. Atualmente, 24 desses países utilizam a irradiação de alimentos para fins comerciais ${ }^{[\mathbf{9 - 1 2}]}$.

O processamento de alimentos por radiação ionizante com doses de radiação intermediárias, entre 1 e 10 kGy, é conhecido como radicidação, radiopasteurização ou pasteurização a frio. Aplicado juntamente com os métodos tradicionais de tratamento e conservação de alimentos, pode reduzir o número de microorganismos patogênicos em produtos cárneos, seus derivados e outros alimentos $^{[9-12]}$.

A radiopasteurização é capaz de controlar a transmissão de doenças originárias de alimentos contaminados e muitas vezes de importância mundial, como a salmonelose, aumentar a vida útil e reduzir as perdas durante as fases de estocagem, processamento, distribuição e comercialização, disponibilizando alimentos sadios e seguros para uma população mundial em expansão sem alterar as propriedades nutricionais e organoléptica ${ }^{[9-12]}$.

Na radiopasteurização de produtos cárneos, as doses são selecionadas de acordo com os níveis de tratamento desejados e estão diretamente relacionadas com a população inicial de microorganismos patogênicos presentes no alimento. Assim, são recomendadas doses de 5 - 10 kGy para retardar a deterioração e reduzir, a um nível aceitável, a população de alguns tipos de bactérias patogênicas (por exemplo, espécies de Salmonella, Pseudomonas, Achromobacter e Escherichia coli, entre outras) ${ }^{\left[{ }^{\text {9-12] }} \text {. }\right.}$

Atualmente, a pasteurização de produtos cárneos de maior interesse está voltada para a redução do número de deteriorantes e patógenos presentes e para o aumento do tempo de prateleira. Nestes casos os produtos são irradiados pré-embalados, com doses de radiação de até $10 \mathrm{kGy}$ na presença de ar. Este 
processo, além de apresentar custos competitivos frente aos processos convencionais, não causa alteração significativa nas características físicas e sensoriais dos produtos tratados, uma vez que a oxidação lipídica praticamente não é favorecida ${ }^{[10-12]}$.

O processo de irradiação de alimentos com doses baixas, entre 50 e 1000 Gy, é denominado radurização e é usado para inibir a germinação de raízes e tubérculos, controlar a infestação de cereais, farinhas, frutas, legumes, vegetais, especiarias e grãos por insetos e ácaros, aumentar o período de maturação de algumas frutas e retardar a deterioração fúngica de frutas e hortaliças ${ }^{[10-12]}$.

Nos processos de radioesterilização em geral, a dose mínima de radiação ionizante recomendada é de 25 kGy. Este processo de esterilização é denominado tecnicamente radapertização, radioesterilização ou esterilização comercial à frio. Para alguns alimentos pode-se utilizar doses de até 75 kGy ${ }^{\text {[10-12] }}$.

Em 1993, carnes de frango passaram a ser irradiadas nos Estados Unidos para controle da Salmonella. Em dezembro de 1997, o FDA aprovou a irradiação de carnes vermelhas resfriadas ou congeladas. Essa medida renovou o interesse mundial na radiopasteurização de carnes frescas "in natura" e derivados pré-embalados, com vistas à manutenção da qualidade fitossanitária por longos períodos e à ampliação do alcance do sistema de distribuição desses produtos perecíveis. Esses produtos são irradiados pré-embalados, para prevenir a recontaminação microbiana ${ }^{[\mathbf{1 0 - 1 2}]}$.

\subsection{A radiação ionizante e os materiais de embalagens}

A radiação ionizante pode causar mudanças nas propriedades físicas e químicas dos materiais poliméricos ${ }^{[42-44]}$. 
Quando um polímero é irradiado, ocorrem, simultaneamente, duas reações diferentes: a cisão da cadeia polimérica principal e as ligações químicas entre moléculas poliméricas (reticulação). Estas reações são concorrentes e a predominância de uma sobre a outra depende da estrutura química do polímero, das condições da irradiação e de fatores específicos do material que irá absorver a energia ${ }^{[15,16,45]}$.

\subsubsection{Efeitos da radiação ionizante sobre os materiais poliméricos}

A interação da radiação ionizante com a matéria promove eventos físicos, químicos e físico-químicos. Então, quando um determinado polímero ou filme polimérico é submetido a radiação ionizante pode sofrer várias modificações na sua estrutura física e química induzidas pela interação da radiação com o polímero $^{[15-17,45]}$.

A interação da radiação ionizante com compostos orgânicos produz principalmente cátions, ânions, radicais livres e espécieis excitadas. Quando os polímeros são irradiados os radicais livres e demais espécieis formadas podem ficar aprisionadas por algum tempo na matriz polimérica causando transformações denominadas efeitos pós-irradiação ${ }^{[27,43]}$.

Quando uma molécula polimérica $\mathbf{A B}$ é sobmetida a radiação ionizante, podem ocorrer as seguintes transformações químicas ou, eventos primários por ação da radiação ionizante ${ }^{[45-47]}$ :

$1^{\text {a }) ~ A ~ m o l e ́ c u l a ~ p o d e ~ s e r ~ i o n i z a d a, ~ s e ~ a ~ e n e r g i a ~ t r a n s f e r i d a ~ p e l a ~ p a r t i ́ c u l a ~ i n c i d e n t e ~}$ para um elétron orbital da molécula, for maior que a energia de ligação desse elétron:

$$
A B M A^{+}+e^{-}
$$


$2^{\mathrm{a}}$ ) A ionização pode levar a fragmentação dessa molécula, conforme ilustrado na equação (2), onde "B" é um fragmento neutro, o qual pode ser um radical livre:

$$
A B M A^{+}+B+e^{-}
$$

$3^{\mathrm{a}}$ ) Se a energia transferida para o elétron orbital for menor que aquela requerida para o processo de ionização, pode ocorrer excitação eletrônica, elevando o nível de energia desse elétron orbital para um estado excitado:

$$
A B M \rightarrow B^{*}
$$

$4^{a}$ ) Este processo pode ser seguido, imediatamente, pela dissociação da molécula excitada eletronicamente " $A B$ " " em radicais livres:

$$
\mathrm{AB}^{*} \rightarrow \mathrm{A}^{\bullet}+\mathrm{B}^{\bullet}
$$

$5^{\text {a }) ~ A l t e r n a t i v a m e n t e, ~ a ~ m o l e ́ c u l a ~ e x c i t a d a ~ " ~} A B$ " pode ser desativada, liberando calor (Q) ou emitindo um quantum de luz (hv):

$$
A B^{*} \rightarrow A B+Q(\text { ou hv) }
$$

$6^{\text {a }}$ ) Os elétrons formados por meio dos processos (1 e 2), elétrons primários, transferem parte da energia cinética para o meio, ionizando e excitando mais algumas moléculas $A B$. Não tendo mais energia suficiente para excitar ou ionizar mais moléculas, perdem o restante de sua energia interagindo com uma molécula neutra:

$$
A B+e^{-} \rightarrow \mathrm{AB}^{-}\left(\text {ou } A^{\bullet}+B^{-}\right)
$$


ou se recombinam com um íon positivo para formar uma molécula excitada (7):

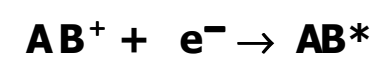

(7)

sendo: " $M \longrightarrow$ " = radiação ionizante.

A interação inicial de cada fóton de raios gama com os polímeros produz alguns elétrons rápidos (elétrons primários), similar a irradiação de um feixe de elétrons, os quais em sua trajetória dão origem a elétrons secundários a distância de alguns microns do evento primário ${ }^{[40]}$. À temperatura ambiente, ocorre recombinação elétron-cátion rápida gerando polímeros em estados altamente excitados $\left(P^{*}\right)$ À temperaturas baixas, isto é, temperaturas menores que $-100^{\circ} \mathrm{C}$, os elétrons secundários ejetados podem ser aprisionados na matriz polimérica ${ }^{[15,16,40]}$.

O polímero em seu estado excitado $\left(P^{*}\right)$, dissipa seu excesso de energia por meio da cisão das ligações da cadeia polimérica, dando origem aos radicais livres. A cisão da ligação $\mathrm{C}-\mathrm{H}$ é preferencial à cisão da ligação $\mathrm{C}-\mathrm{C}$, porque ocorre migração de energia ao longo das ligações C-C e a energia depositada nas ligaçõs C-H não migram. Além disso, nos estados altamente excitados, as ligações C-C são mais estáveis que as ligações $\mathrm{C}^{-} \mathrm{H}^{[\mathbf{1 5}, \mathbf{1 6}]}$.

Os estudos sobre o efeito da radiação em polímeros concentram-se, principalmente, nas reações posteriores a formação dos radicais livres. Entre estas reações destacam-se:

a) Polimerização:

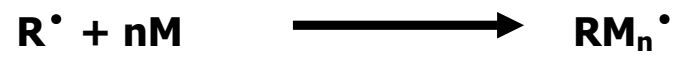

na qual : $M=$ monômero

$$
\mathrm{RM}^{\bullet}=\text { macroradical }
$$


b) Cisão de ligações, gerando ligações cruzadas (reticulação):

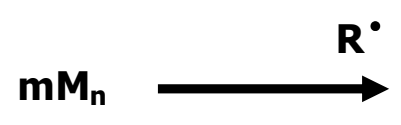

A

na qual : $\quad A=$ macromolécula com ligações cruzadas

c) Cisão localizada em cadeias, gerando degradação

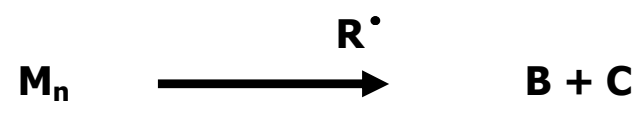

na qual : $B$ e $C=$ moléculas menores que $M_{n}$

d) Enxertia ("graftização") de monômeros em polímeros:

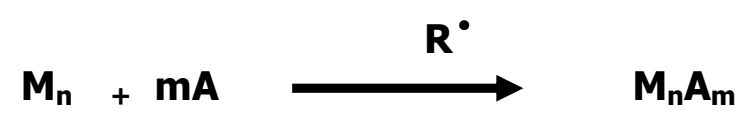

As modificações causadas pela radiação ionizante nos polímeros dependem das condições de processo, isto é, tipo de radiação, presença de oxigênio ou diferentes atmosferas, grau de cristalinidade e homogeneidade do material polimérico que irá absorver a energia, aditivos adicionados aos materiais plásticos para obter um efeito técnico no produto final, como por exemplo: antioxidantes, antiestáticos, espumantes, antiespumantes, cargas, modificadores de impacto, estabilizantes, plastificantes, lubrificantes, protetores de ultravioleta (UV), conservantes, endurecedores, substâncias utilizadas com a finalidade de proporcionar um meio adequado para a polimerização: emulsificantes, agentes tensoativos, reguladores de $\mathrm{pH}$, solventes, entre outros ${ }^{[15,16]}$.

Como já foi dito anteriormente, os principais efeitos da radiação ionizante sobre os polímeros incluem a cisão da cadeia polimérica principal e as ligações químicas entre moléculas poliméricas diferentes (processo de reticulação). 
Geralmente os polímeros contendo carbonos quaternário na cadeia principal tendem a degradar, enquanto os demais tendem a reticular. Polímeros contendo anel benzênico têm uma maior resistência à radiação, necessitando de uma dose maior para reticular ${ }^{[15,16]}$.

A degradação de polímeros também é acompanhada pela formação de produtos gasosos, resultante da recombinação dos radicais livres. Estes produtos refletem tanto a composição atômica, como a estrutura molecular do polímero e são, em geral, produzidos em quantidades substanciais ${ }^{[15,16]}$. A degradação também é favorecida pela presença de oxigênio, devido, provavelmente, a formação de peróxidos, os quais impedem a recombinação de radicais no final da cadeia $^{[42-44]}$.

Os radicais livres formados durante a irradiação podem também se recombinar com o oxigênio do ar ou promover a reticulação entre as cadeias poliméricas. Se o polímero for um sólido, como é o caso dos filmes poliméricos, os radicais podem, ainda, ficar aprisionados por um tempo considerável após a irradiação e causar, algum tempo depois, transformações químicas no filme polimérico. Se estas transformações incluírem a degradação, o que geralmente acontece, poderá ocorrer possíveis liberação de compostos de massa molar média baixa, alteração das características físico-químicas e a diminuição das propriedades mecânicas do polímero ${ }^{[15,16]}$.

Durante o processo de irradiação, a energia é distribuída pela cadeia do polímero. O local onde ocorre a cisão é determinado pela estereoquímica, pelo grau de cristalinidade e pela energia de dissociação das ligações dos grupos contidos no polímero ${ }^{[15,16]}$. Na Tabela 1 é apresentada a energia e a distância de ligação de algumas ligações primárias comuns em sistemas poliméricos ${ }^{[22]}$ : 
TABELA 1 - Energia e distância de ligação de algumas ligações primárias comuns em sistemas poliméricos

\begin{tabular}{|c|c|c|c|}
\hline Ligação & $\begin{array}{c}\text { Estabilidade } \\
\text { da ligação } \\
\text { com relação à } \\
\text { ligação C-C }\end{array}$ & $\begin{array}{c}\text { Energia de } \\
\text { ligação } \\
(\mathrm{kcal} / \mathrm{mol})\end{array}$ & $\begin{array}{c}\text { Distância de } \\
\text { ligação } \\
(\AA ̊)\end{array}$ \\
\hline $\mathrm{C} \equiv \mathrm{N}$ & \multirow{12}{*}{ 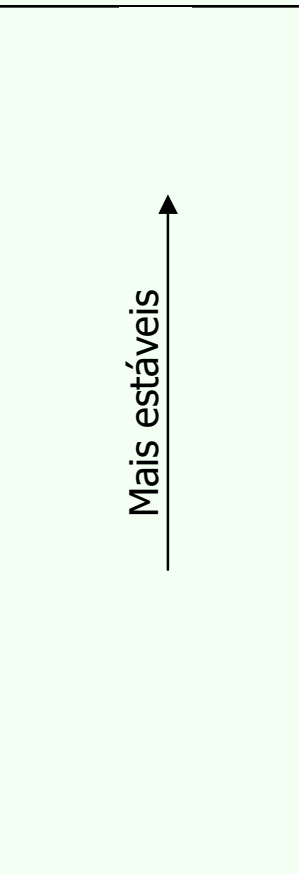 } & 213 & 1,16 \\
\hline$C \equiv C$ & & 194 & 1,20 \\
\hline$C=O$ & & 171 & 1,23 \\
\hline $\mathrm{C}=\mathrm{N}$ & & 147 & 1,27 \\
\hline $\mathrm{C}=\mathrm{C}$ & & 147 & 1,34 \\
\hline $\mathrm{C}=\mathrm{S}$ & & 114 & 1,71 \\
\hline $0-\mathrm{H}$ & & 111 & 0,96 \\
\hline $\mathrm{C}-\mathrm{H}$ & & 99 & 1,09 \\
\hline $\mathrm{N}-\mathrm{H}$ & & 93 & 1,01 \\
\hline $\mathrm{Si}-\mathrm{O}$ & & 88 & 1,64 \\
\hline $\mathrm{C}-\mathrm{O}$ & & 84 & 1,43 \\
\hline $\mathrm{C}-\mathrm{C}$ & & 83 & 1,54 \\
\hline $\mathrm{S}-\mathrm{H}$ & \multirow{7}{*}{ | } & 81 & 1,35 \\
\hline $\mathrm{C}-\mathrm{Cl}$ & & 79 & 1,77 \\
\hline $\mathrm{C}-\mathrm{N}$ & & 70 & 1,47 \\
\hline $\mathrm{C}-\mathrm{Si}$ & & 69 & 1,87 \\
\hline$C-S$ & & 62 & 1,81 \\
\hline S-S & & 51 & 2,04 \\
\hline O-O & & 33 & 1,48 \\
\hline
\end{tabular}

No processo de reticulação por radiação, se o polímero é irradiado por um tempo considerável o material pode tornar-se uma molécula gigante, que poderá se quebrar somente por cisão de ligações químicas, geralmente, por aquecimento à temperaturas adequadas ${ }^{[42-44]}$. 
As alterações químicas provenientes da reticulação incluem aumento da viscosidade, diminuição da solubilidade em solventes e alteração na temperatura de transição vítrea da fase amorfa ${ }^{[42-44]}$.

A literatura apresenta diferentes unidades, as quais estão relacionadas entre si, para descrever a absorção da radiação pelos materiais ${ }^{[41,43]}$. As principais unidades e a maneira como elas estão relacionadas são apresentadas a seguir:

$$
1 \mathrm{~Gy}=100 \mathrm{rad}=1 \mathrm{~J} / \mathrm{kg}=6,24 \times 10^{15} \mathrm{ev} / \mathrm{g}=10^{4} \mathrm{erg} / \mathrm{g}
$$

As maiores mudanças químicas que ocorrem nos polímeros pela ação da radiação ionizante são ${ }^{[43-47]}$ :

cisão e reticulação simultâneas das cadeias poliméricas e o seu efeito na rede cristalina, os quais vão determinar as mudanças nas propriedades do polímero;

$>$ formação de gases e produtos da radiólise de massa molar baixa;

$>$ formação de ligações insaturadas.

As mudanças induzidas pela radiação nos polímeros dependem da estrutura química do polímero, aditivos usados na composição da resina, histórico do processamento da resina, e condições específicas da irradiação, isto é, dose absorvida, atmosfera de irradiação e, em certos casos, a taxa de dose $\mathrm{e}^{[43-47]}$.

As mudanças causadas pela radiação ionizante são de grande importância para as embalagens de alimentos porque podem afetar diretamente a qualidade dos gêneros alimentícios irradiados. A ação da radiação, pode, por exemplo, alterar as propriedades de barreira (permeabilidade) das embalagens e propiciar a liberação de contaminantes, os quais podem migrar para o alimento acondicionado ${ }^{[12-14,52-57]}$. 
Os produtos formados durante a irradiacão, os monômeros e oligômeros residuais, provenientes tanto do processamento químico da resina como do tratamento por radiação, podem migrar para os alimentos, afetando as suas propriedades sensoriais (alteração do odor/sabor do produto) e a segurança dos alimentos pré-embalados, resultando em riscos toxicológicos e sensoriais que devem ser avaliados ${ }^{[12-14,52-56]}$.

A ocorrência de odor e sabor estranhos nos produtos pré-embalados, tratados por radiação ionizante, pode ser proveniente dos produtos voláteis gerados pela degradação da resina, dos resíduos de monômeros e oligômeros, dos aditivos que são incorporados a ela e dos compostos produzidos pela radiólise causada pela irradiação ${ }^{[12-14,52-56]}$.

Os efeitos imediatos da radiação sobre as propriedades ópticas dos materiais de embalagens são a mudança de cor (notadamente amarelecimento) e as modificação das suas características originais de barreira à luz. A radiação ionizante pode induzir a formação de centro de cores permanentes e nãopermanentes nos materiais poliméricos ${ }^{[14,52,57,58]}$.

Os centros de cores permanente correspondem a formação de cromóforos conjugados, estáveis dentro da matriz polimérica, enquanto os centros de cores não-pemanentes estão associados a presença de radicais livres presos na matriz. Quando a irradiação ocorre na presença de ar, o oxigênio presente pode reagir com os radicais livres presos na matriz polimérica, formando centro de cores, os quais desaparecem posteriormente em razão da ocorrência das reações de terminação radical-radical[ ${ }^{[\mathbf{2 2}, \mathbf{5 7}]}$.

Os materiais utilizados para o processamento por radiação ionizante devem apresentar resistência físico-química à radiação, não devem sofrer redução das suas características de proteção, nem transferir substâncias tóxicas ou causar odores e sabores estranhos ao produto acondicionado ${ }^{[14,52-56]}$. 
Os materiais de embalagens mais estudados e usados nos alimentos tratados por radiação são os plásticos, notadamente os termoplásticos, em forma de filmes ou laminados, que podem ter como substrato papel, alumínio ou cartão. São praticamente os mesmos materiais utilizados nos processos tradicionais de conservação, embora sejam relevantes as seguintes considerações: como consequência da irradiação, as embalagens são passíveis de alterações químicas e físicas, causadas, geralmente, pela reticulação e degradação, podendo ocorrer desprendimento de gases e substâncias capazes de afetar as características dos

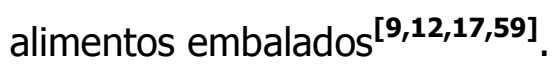

O efeito da radiação nos materiais de embalagens flexíveis para alimentos e a sua adequação aos processos industriais de radiação é objeto de estudo, desde a década de 70, no Canadá, Estados Unidos, França e Reino Unido, assim como em vários outros. Com base nestes estudos estes países aprovaram vários materiais para embalagens de alimentos, para uso nos processos de radioesterilização e de pasteurização por irradiação ${ }^{[\mathbf{9}}{ }^{\mathbf{5 9}]}$. 


\section{MATERIAIS E MÉTODOS}

\subsection{Materiais}

\subsubsection{Materiais de embalagem}

Os materiais de embalagem avaliados nesta pesquisa foram o filme monocamada Unipac PE 60, à base de polietileno de baixa densidade, usado em embalagens para o acondicionamento de aves "in natura" (inteiras, carcaças e cortes) (FIG.18) e o filme multicamadas Lovaflex $\mathrm{CH}$ 130, uma estrutura coextrusada $\mathrm{PA}-\mathrm{Co} / \mathrm{EVOH} / \mathrm{PE}$, composta de nove camadas de filme. Lovaflex $\mathrm{CH}$ 130 é uma das estruturas coextrusadas mais usadas em embalagens termoformadas para acondicionamento a vácuo de salsichas, linguiças e frios fatiados. Na FIG.19 é mostrado uma imagem (corte transversal) da estrutura Lovaflex $\mathrm{CH} 130$ obtida com o aumento de 1000 vezes, utilizando o microscópio Leica tipo DM LM/P e fotografada com a câmara digital Leica DC 300. Utilizou-se o software Leica QWin para o tratamento da imagem e a medição das espessuras das camadas da estrutura.

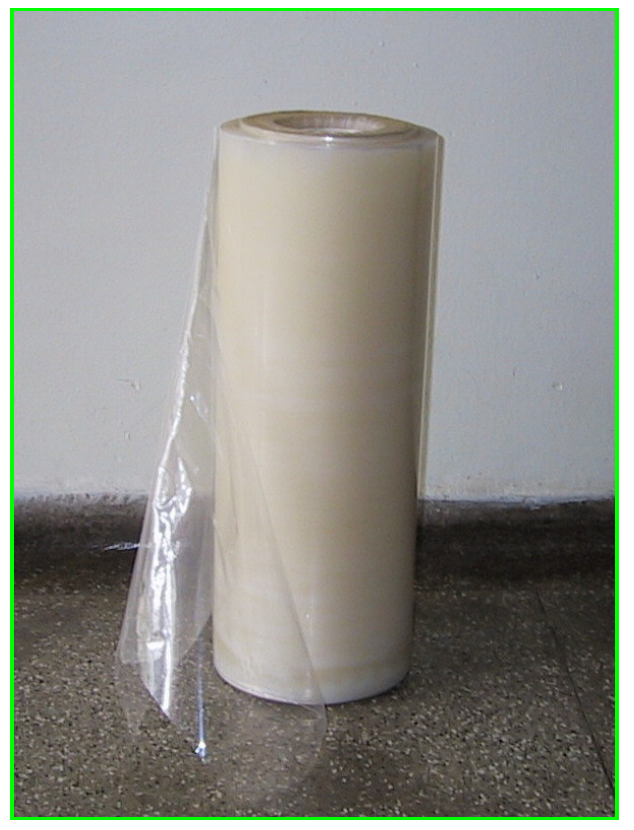

FIGURA 18 - Bobina do filme monocamada Unipac PE 60. 


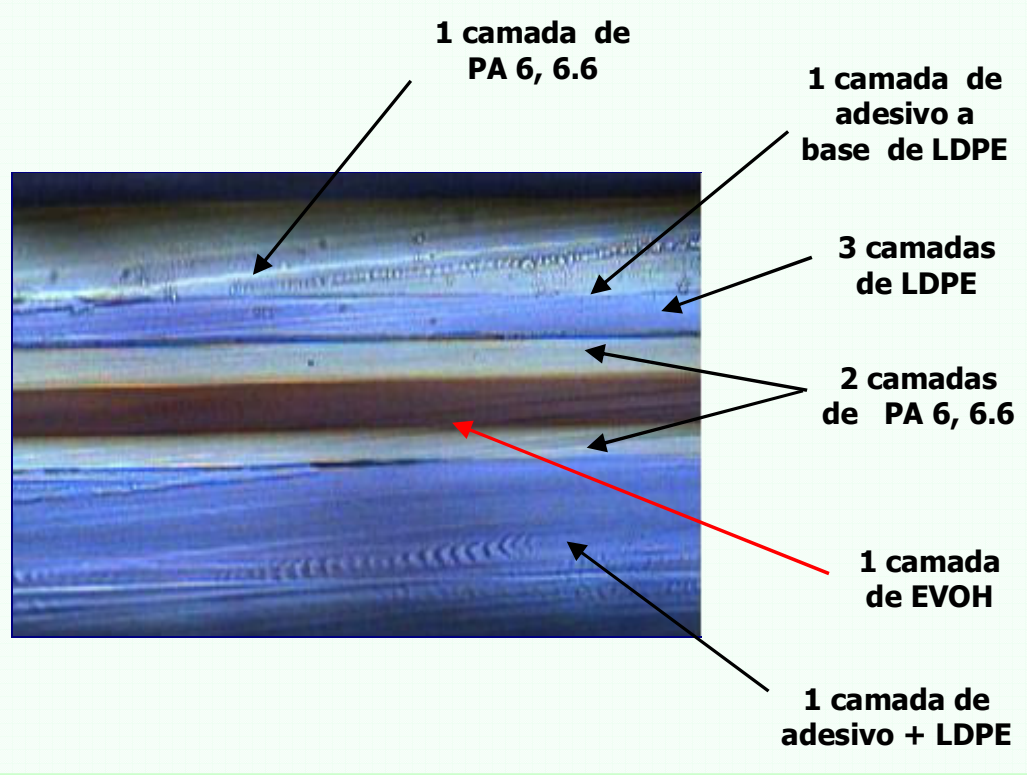

FIGURA 19 - Imagem (corte transversal) da estrutura Lovaflex CH 130 obtida com o aumento de 1000 vezes, utilizando o microscópio Leica tipo DM $\mathrm{LM} / \mathrm{P}$.

Para este trabalho foram selecionadas bobinas de lotes de produção comercial do filme Unipac PE 60 e do Lovaflex CH 130. Na Tabela 2 são apresentadas as principais características dos filmes, fornecidas pelo fabricante.

TABELA 2 - Principais características dos filmes Unipac PE 60 e Lovaflex CH 130

\begin{tabular}{|c|c|c|c|}
\hline Materiais & Nome ${ }^{(a)}$ & Espessura $(\mu \mathrm{m})$ & Aplicação \\
\hline $\operatorname{LDPE}^{(b)}$ & Unipac PE 60 & $\begin{array}{c}60 \\
(58-62)^{(d)}\end{array}$ & $\begin{array}{l}\text { Embalalgens } \\
\text { monocamada } \\
\text { para aves } \\
\text { frescas inteiras, } \\
\text { carcaças e } \\
\text { cortes }\end{array}$ \\
\hline$\overline{\mathrm{PA}-\mathrm{co} / \mathrm{EVOH} / \mathrm{PE}^{(c)}}$ & Lovaflex $\mathrm{CH} 130$ & 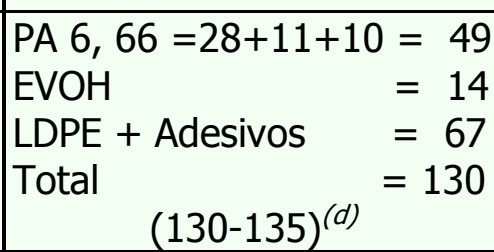 & $\begin{array}{c}\text { Embalagens } \\
\text { multicamadas } \\
\text { termoformadas } \\
\text { para salsichas e } \\
\text { fatiados }\end{array}$ \\
\hline
\end{tabular}

(a) Referência do Fabricante:"Unipac Embalagens Ltda."; (b) Polietileno de Baixa Densidade; (c) Copolímero de Poliamida 6 e Poliamida 6,6/ Copolímero de Etileno e Álcool Vinílico/Polietileno; (d) Variação da espessura. 


\section{$5.2 \quad$ Métodos}

\subsubsection{Ensaios de irradiação}

Os ensaios de irradiação foram realizados com doses de radiação entre 0 e $30 \mathrm{kGy}$, à temperatura ambiente e na presença de ar, utilizando raios gama ou feixe de elétrons. Estas condições foram estabelecidas com vista a atender os seguintes processos de irradiação:

pasteurização por radiação de produtos cárneos pré-embalados para a redução do número de deteriorantes e patógenos presentes e para o aumento do tempo de prateleira (10 kGy);

radioesterilização de embalagens para posterior acondicionamento de produtos alimentícios em condições assépticas (25 kGy).

\subsubsection{Irradiações com raios gama}

As amostras dos filmes foram colocadas em um porta-amostra cilíndrico confeccionado em aço inoxidável, devido a disponibilidade do material e facilidade de confeç̧ão, e submetidas a radiação gama na fonte de ${ }^{60} \mathrm{Co}$ do tipo "Gammacell 220" ("Atomic Energy of Canada Limited"), com $4.113 \mathrm{Ci}$ de atividade em Janeiro/2006, pertencente ao CTR-IPEN/CNEN-SP (FIG.20). Foi utilizada uma da taxa de dose variando entre 3,48 e 4,43 kGy/h. A confirmação da dose total de radiação absorvida foi realizada por dosimetria, utilizando-se dosímetros de triacetato de celulose "CTA-FTR-125" da Fuji Film. 


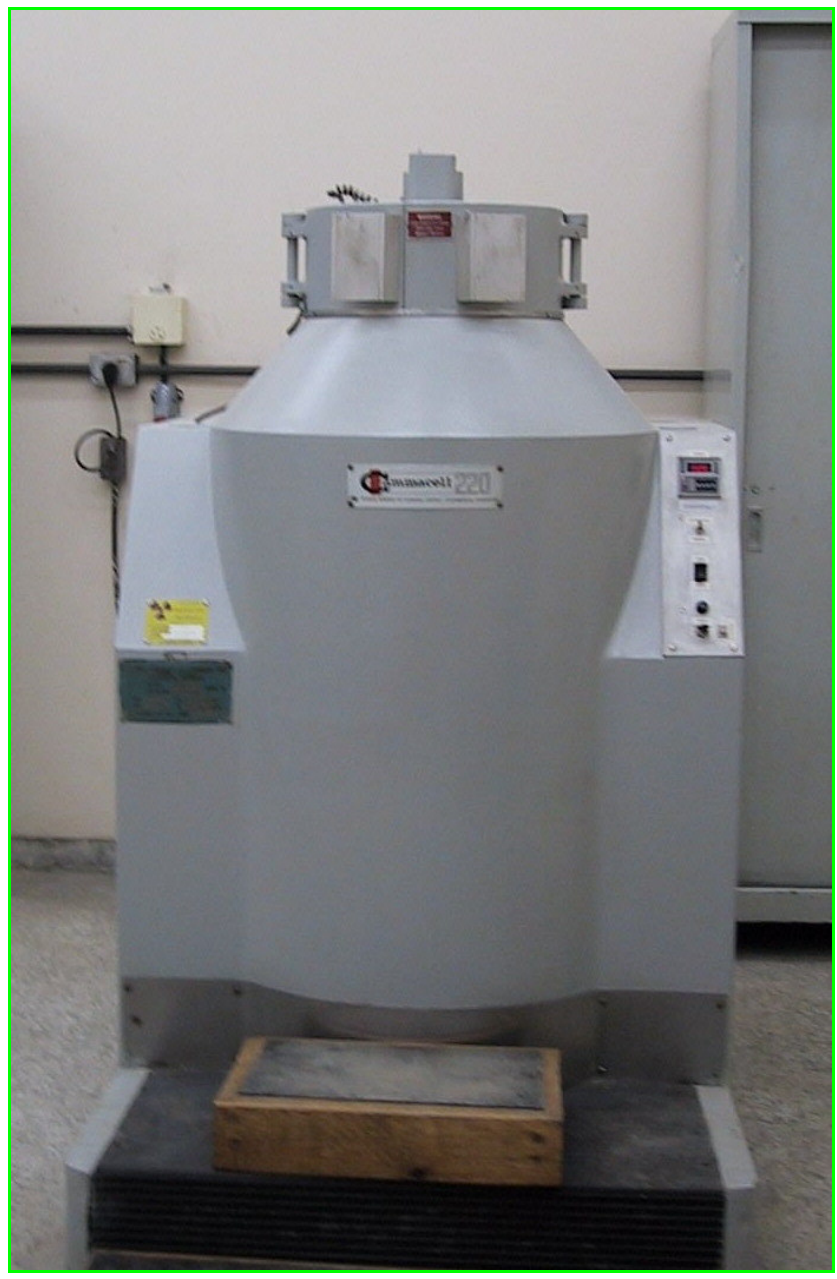

FIGURA 20 - Irradiador gama de cobalto-60 tipo Gammacell 220

\subsubsection{Irradiações com feixe de elétrons}

Nestes ensaios as amostras dos filmes foram colocadas em portaamostras do tipo bandeja, confeccionados em alumínio e revestidos com madeira, para minimizar o efeito do retroespalhamento dos elétrons, e irradiadas à taxa de

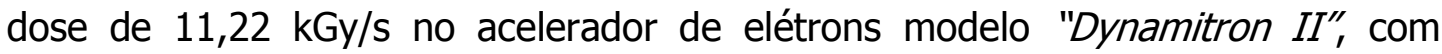
energia de 1,5 MeV, corrente de $25 \mathrm{~mA}$ e $37,5 \mathrm{~kW}$ de potência, pertencente ao CTR-IPEN/CNEN-SP (FIG.21). A confirmação da dose total de radiação absorvida pelas amostras foi realizada por dosimetria, utilizando-se dosímetros de triacetato de celulose "CTA-FTR-125" da Fuji Film. 


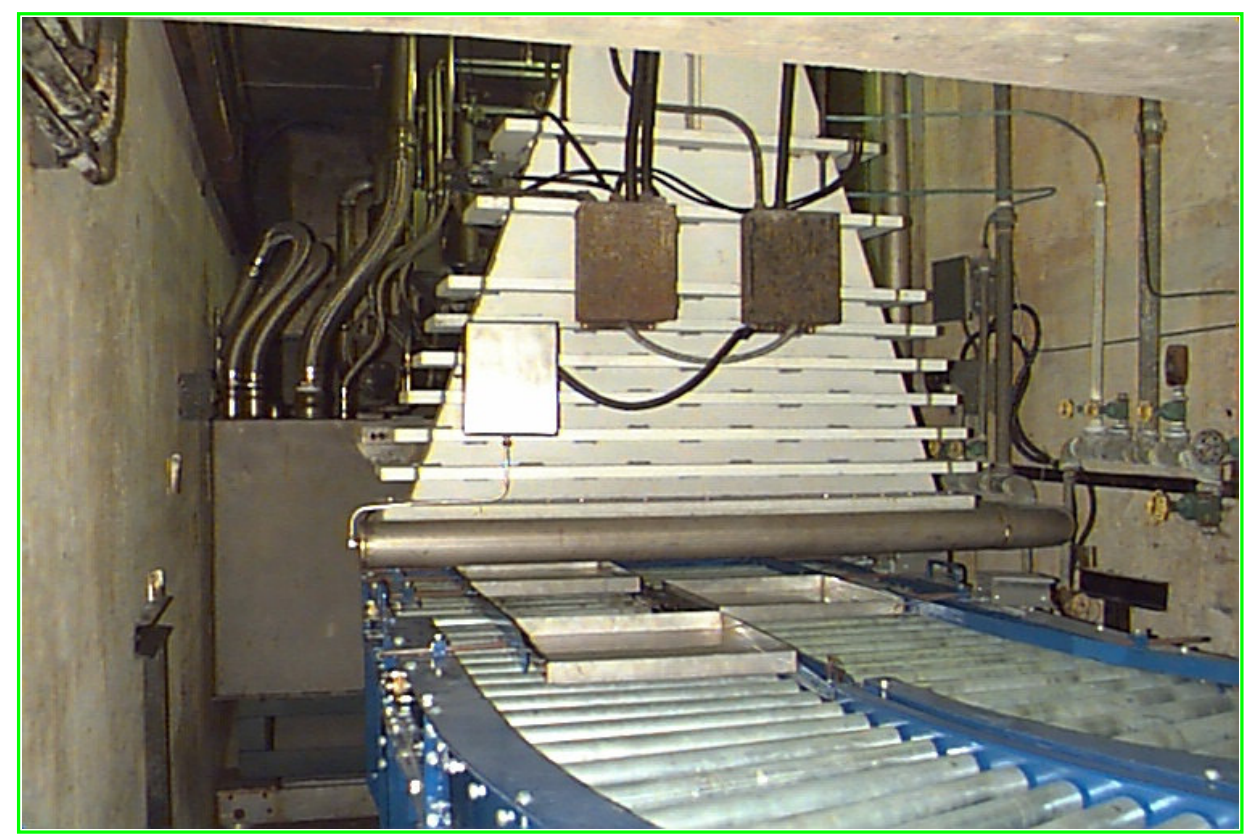

FIGURA 21 - Acelerador de elétrons modelo Dynamitron II

Concluída as irradiações, para evitar a influência da luz natural ou artificial sobre o resultado das análises, as amostras foram colocadas dentro de sacos plásticos pretos, os quais foram identificados e guardados até a realização das análises.

\subsubsection{Análises}

Para avaliar o comportamento das propriedades dos materiais em função das doses de radiação absorvidas, as análises foram realizadas uma semana após a irradiação e repetidas dois meses após a irradiação para os ensaios de tração e análises de UV-visível e três meses após a irradiação para os ensaios de permeabilidade. Estes tempos foram estabelecidos de modo a considerar também a contribuição dos efeitos pós-irradiação. Os ensaios de migração total e as análises de produtos voláteis, foram realizados uma semana após a irradiação e não foram repetidos. Os ensaios de migração total em 
simulantes de alimentos não foram repetidos, porque os valores médios de resíduos nas amostras analisadas uma semana após a irradiação não foram significativos, quando comparados ao limite máximo de migração total recomendado pela legislação em vigor. Com relação as análises de produtos voláteis, estas não foram repetidas porque as análises de cromatografia gasosa, realizadas uma semana após a irradiação, não detectaram quaisquer picos.

\subsubsection{Ensaios mecânicos}

\subsection{Ensaios mecânicos de tração}

Foram realizados ensaios de tração utilizando o dinamômetro da marca INSTRON, modelo 5567, pertencente ao CTR-IPEN/CNEN-SP, de acordo com a metodologia descrita na norma ASTM D 882-91 ${ }^{[60]}$ (FIG.22). Os ensaios foram realizados no sentido "DM" (direção de máquina) em quatro amostras, dos filmes irradiados e não irradiados, de mesmo tamanho e espessuras obtidas aleatoriamente.

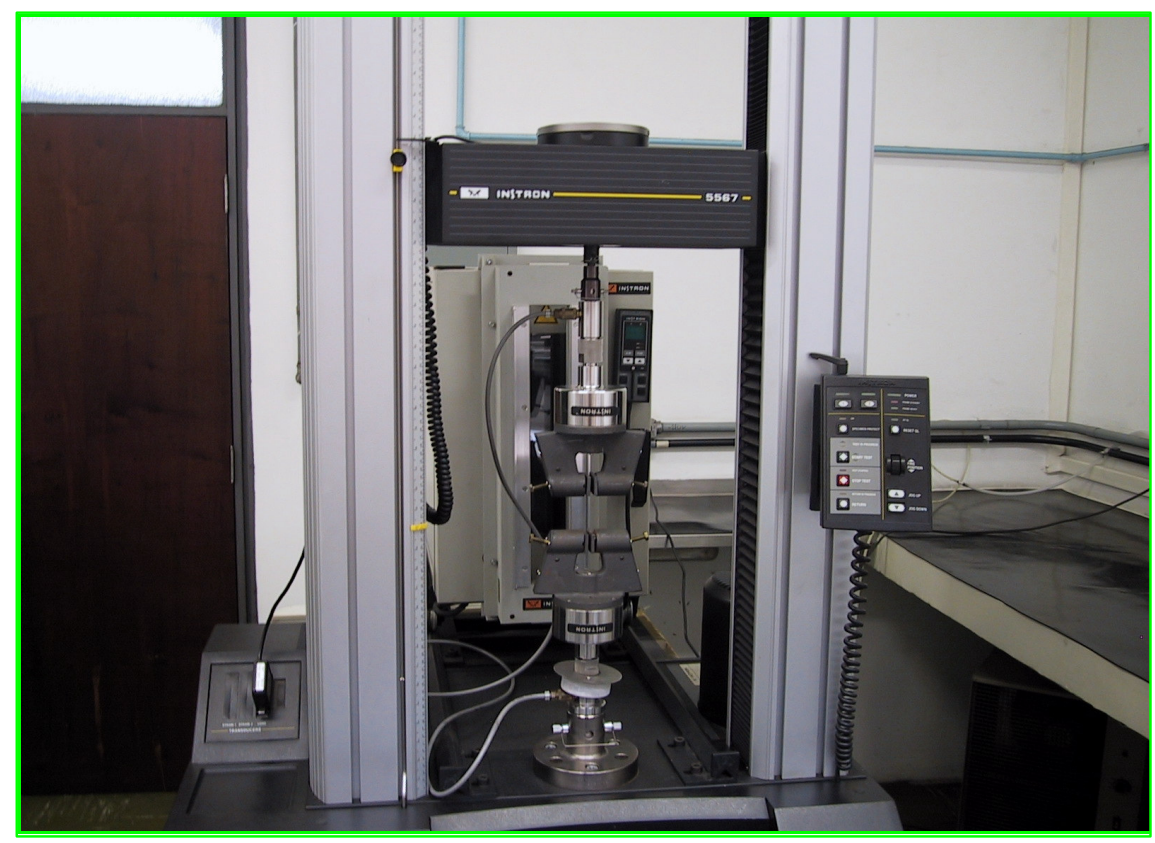

FIGURA 22 - Dinamômetro da marca INSTRON, modelo 5567 


\subsection{Ensaios mecânicos de resistência à perfuração}

Foram realizados ensaios de resistência à perfuração utilizando o dinamômetro da marca INSTRON, modelo 5567 e acessórios, pertencente ao Laboratório da Garantia da Qualidade da Unipac Embalagens Ltda. (FIG.23). Os ensaios foram efetuados em quatro amostras, dos filmes irradiados e não irradiados, de mesmo tamanho e espessuras obtidas aleatoriamente, de acordo com a metodologia descrita na norma ASTM F 1306-90 ${ }^{[61]}$.

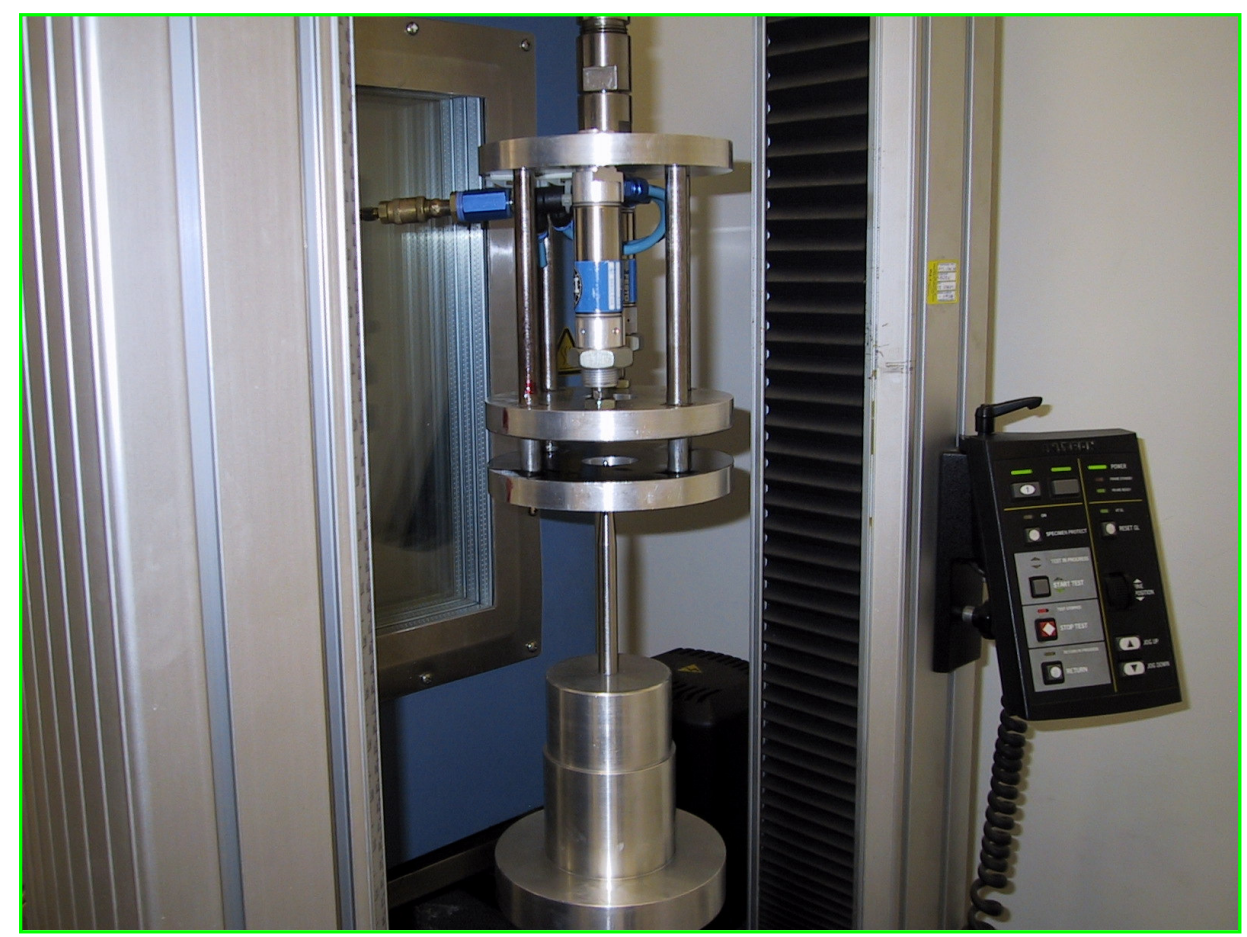

FIGURA 23 - Dinamômetro da marca INSTRON, modelo 5567 e acessórios construídos de acordo com a ASTM F $1306-90^{[61]}$, para os esnsaios de resistência à perfuração.

\subsubsection{Análises de UV/VIS}

As análises de UV/VIS foram realizadas no espectrofotômetro Shimadzu modelo UV1601PC, pertencente ao CTR-IPEN/CNEN-SP, conforme a norma ASTM D 1746-92 ${ }^{[62]}$ (FIG.24). Foram obtidos espectros no modo absorção para avaliar 
as alterações na cor (amarelecimento) e no modo transmitância para avaliar a barreira à luz, expressa como porcentagem de transmitância. Os ensaios foram realizados em quatro amostras, dos filmes irradiados e não irradiados, de mesmo tamanho e espessura e obtidas aleatoriamente.

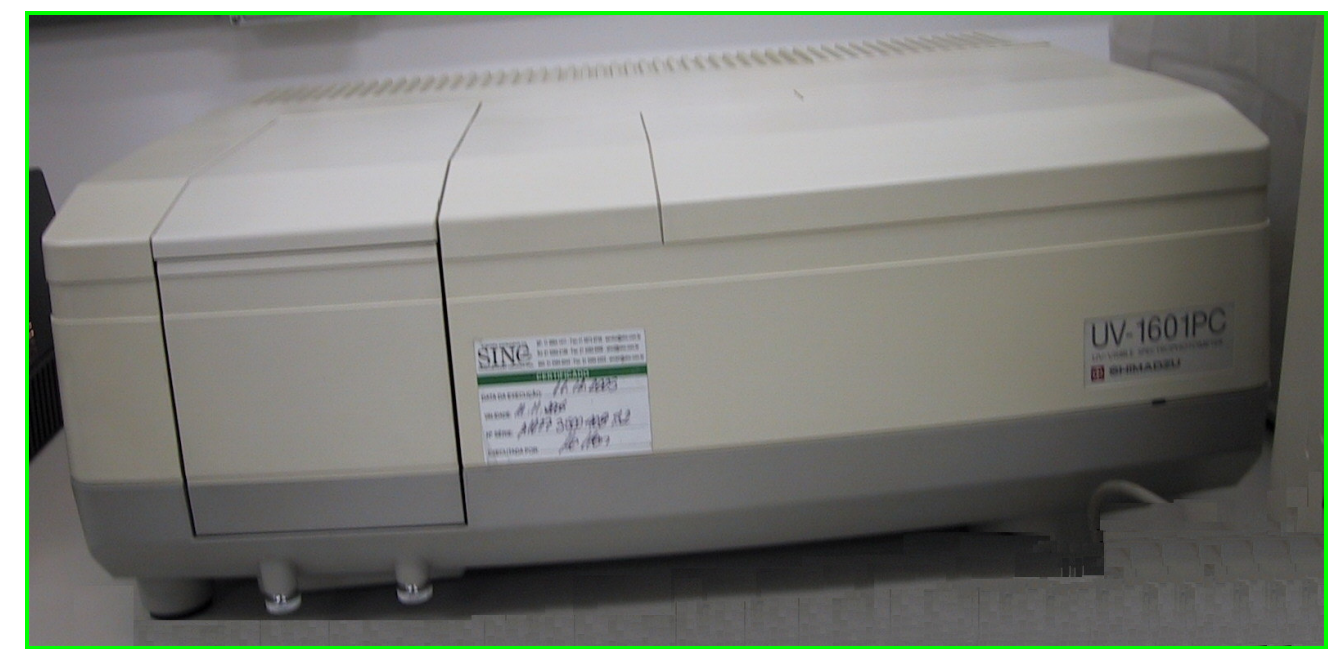

FIGURA 24 - Espectrofotômetro Shimadzu modelo UV1601PC

\subsubsection{Ensaios de permeabilidade}

O processo de extrusão ou coextrusão dos filmes por balão leva a variações de espessura no sentido "DT" (direção transversal), que segundo o fabricante chegam a até $10 \%$ do valor nominal e são suficientes para alterar significativamente os valores de permeabilidade de cada amostra.

Considerando-se que estes testes são bastante demorados e o Laboratório da Garantia da Qualidade do Fabricante, a Unipac, não tinha disponibilidade de equipamentos para realizar uma quantidade de ensaios suficientes para tratamento estatístico deste erro, decidiu-se realizar diversos testes em um trecho dos filmes não irradiados. Para as irradiações nas diversas doses estudadas, foi escolhida uma forma de retirada de amostras que cobrisse as possíveis variações de espessura do material no sentido "DT" e foi realizado 
ensaios em três amostras para cada dose. Determinou-se, então, para o filme Unipac PE não irradiado, uma faixa de permeabilidade correspondente a barreira ao vapor d'água, e para a estrutura Lovaflex $\mathrm{CH}$ 130, uma faixa de permeabilidade correspondente a barreira ao vapor d'água e ao oxigênio.

\subsection{Permeabilidade ao vapor d'água}

As medidas das taxas de transmissão de vapor d'água dos filmes Unipac-PE-60 e Lovaflex CH 130 foram feitas de acordo com a norma ASTM F 372-99 ${ }^{[63]}$, no equipamento Permatran-W Twin, modelo MOCON PN 140-053, da Modern Controls Inc., pertencente ao Laboratório da Garantia da Qualidade da Unipac Embalagens Ltda. (FIG.25).

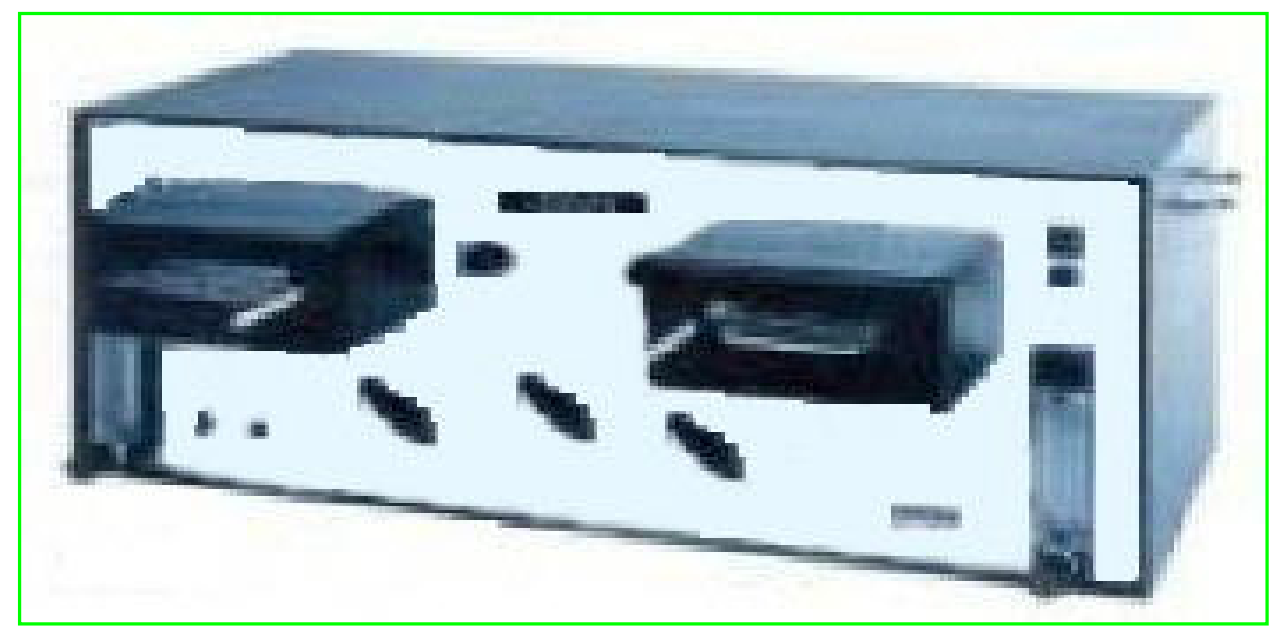

FIGURA 25 - Equipamento Permatran-W Twin, modelo MOCON PN 140-053

\subsection{Permeabilidade ao gás oxigênio}

A determinação da taxa de permeabilidade ao oxigênio das amostras do filme Lovaflex $\mathrm{CH} 130$ foram feitas de acordo com a norma ASTM D $3985-81^{\text {[64], }}$ no equipamento OX-TRAN 2/20, da Modern Controls Inc., pertencente ao 
Laboratório da Garantia da Qualidade da Unipac Embalagens Ltda.. Os testes foram realizados apenas com Lovaflex $\mathrm{CH}$ 130, uma vez que o Unipac-PE-60 é um filme de polietileno de baixa densidade com permeabilidade ao oxigênio acima da capacidade de mensuração do aparelho.

\subsubsection{Ensaios de migração total em simulantes para alimentos}

Embora na metodologia descrita na resolução no 105 da Agência Nacional de Vigilância Sanitária ${ }^{[65]}$, constem diversos simulantes para produtos gordurosos, foram realizados ensaios de migração total nos seguintes simulantes de alimentos: ácido acético (3\%) e n-heptano. Foram selecionados estes simulantes por serem os requeridos, comercialmente no Brasil, para a aprovação e liberação destes filmes para contato com produtos cárneos ${ }^{[66]}$.

\subsubsection{Análises de produtos voláteis}

As análises de produtos voláteis dos filmes Unipac-PE-60 e Lovaflex $\mathrm{CH}$ 130 foram realizadas, por cromatografia gasosa, conforme a metodologia estabelecida pelo Fabricante dos filmes. Utilizou-se o Cromatógrafo modelo Antek 3000, com detetor de ionização de chama, coluna CP-WAX 52CB, nas seguintes condições de operação: gases: nitrogênio, hidrogênio e ar sintético; vazão de "splitter" de $30 \mathrm{~mL} / \mathrm{min}$ e temperatura de $150^{\circ} \mathrm{C}$ (rampa de aquecimento de $\left.20^{\circ} \mathrm{C} / 10 \mathrm{~min}\right)$. 


\section{RESULTADOS E DISCUSSÃO}

\subsection{Aspectos visual e sensorial dos filmes após a irradiação}

\subsubsection{Filme Unipac-PE-60}

As amostras irradiadas com raios gama ou feixe de elétrons em doses superiores a $15 \mathrm{kGy}$ apresentaram leve amarelecimento e odor desagradável de ranço, cujas intensidades aumentaram com a dose de radiação.

\subsubsection{Estrutura Lovaflex $\mathbf{C H}-\mathbf{1 3 0}$}

Todas as amostras apresentaram, após a irradiação e independentemente da dose de radiação aplicada, leve amarelecimento e odor desagradável de ranço, cujas intensidades aumentaram com a dose de radiação.

Contudo, observou-se que após duas semanas da irradiação as amostras retornaram à sua coloração e odor originais.

\subsection{Ensaios mecânicos}

\subsubsection{Ensaios mecânicos de tração}

\subsubsection{Resistência à tração no ponto de ruptura}

Nas Figuras 26 e 27 são apresentados o comportamento da resistência à tração no ponto de ruptura em função da dose de radiação para o filme Unipac PE 60, irradiado com raios gama ou feixe de elétrons. 


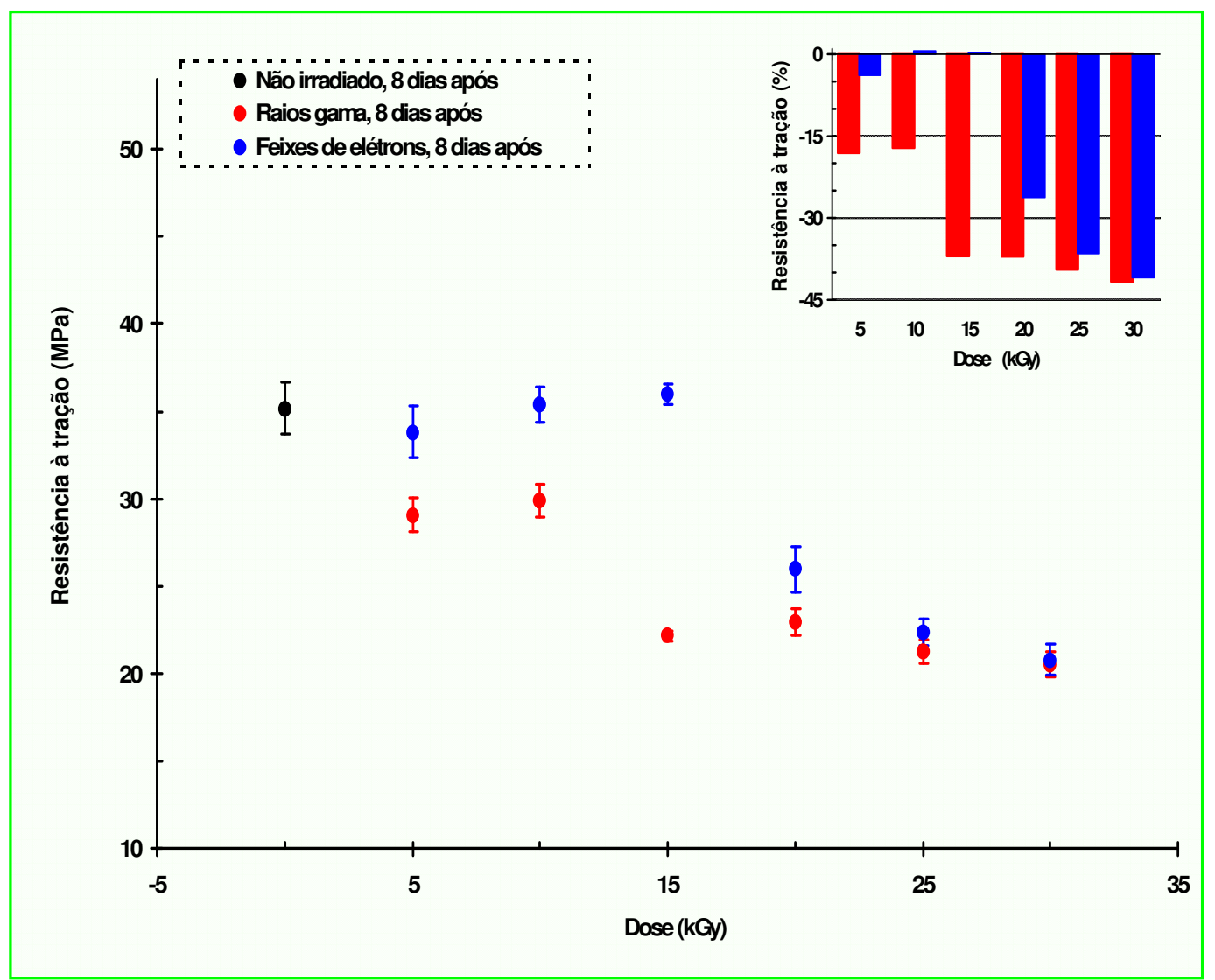

FIGURA 26 - Resistência à tração no ponto de ruptura em função da dose de radiação para o filme Unipac-PE-60, oito dias após a irradiação com raios gama ou com feixe de elétrons.

Observa-se na FIG.26 que o filme Unipac-PE-60 apresentou, uma semana após a irradiação:

a) Redução na sua resistência à tração original (filme não irradiado) com o aumento da dose de radiação com raios gama;

b) Aumento na sua resistência à tração original para as doses de radiação com feixe de elétrons de 10 e 15 kGy e redução a partir de 20 kGy. 
Observa-se na FIG.27 que dois meses após a irradiação com raios gama, ou com feixe de elétrons, o filme Unipac-PE-60 apresentou redução na sua resistência à tração original com o aumento da dose de radiação.

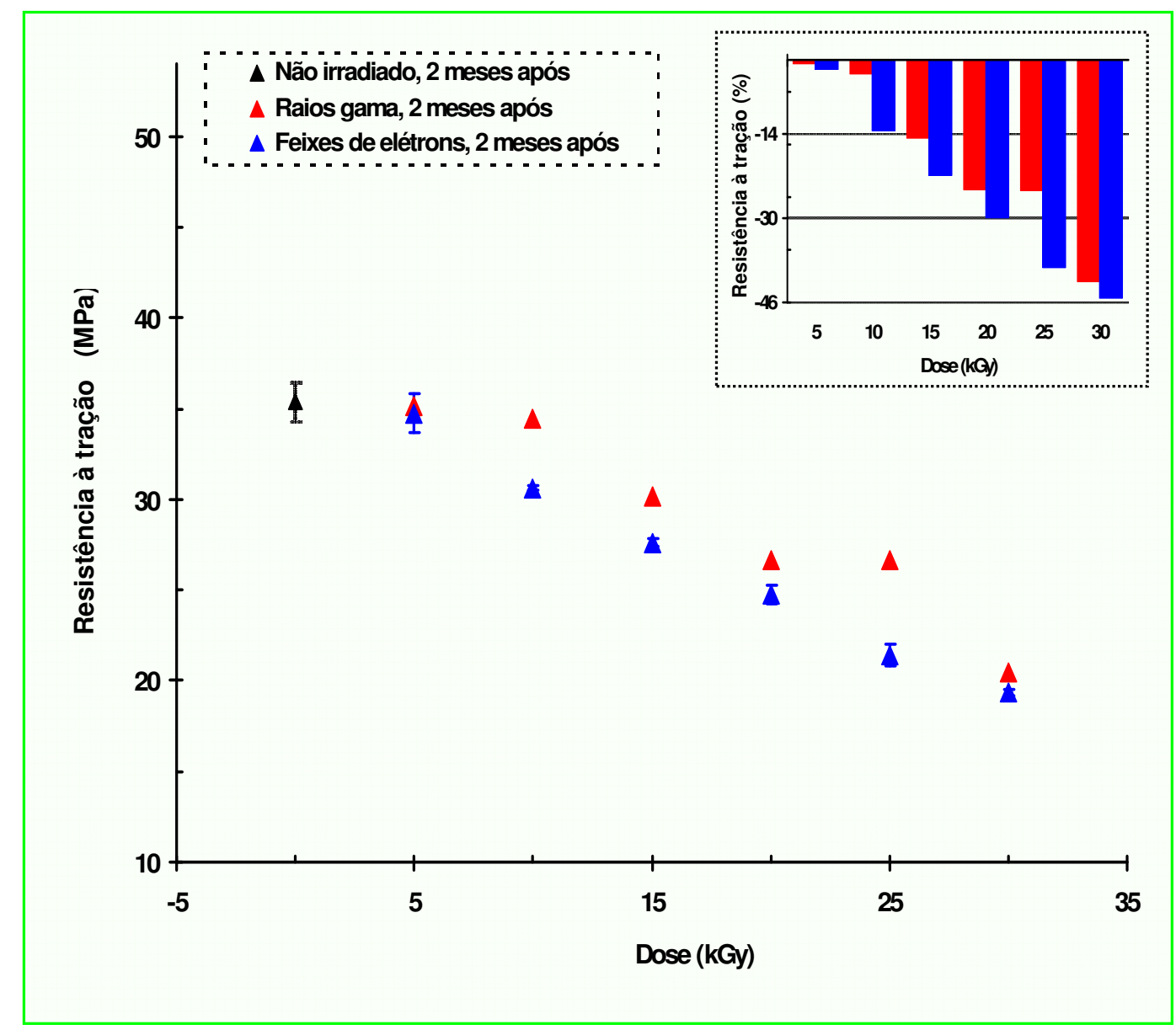

FIGURA 27 - Resistência à tração no ponto de ruptura em função da dose de radiação para o filme Unipac-PE-60, 2 meses após a irradiação com raios gama ou com feixe de elétrons.

Nos diagramas de barras, em detalhe no canto direito das FIG. 26 e 27, estão representadas as variações percentuais da resistência à tração no ponto de ruptura do Unipac-PE-60, oito dias após a irradiação (FIG.26) e dois meses após a irradiação (Fig.27). 
Na FIG.28 é apresentada uma comparação entre os valores da resistência à tração do filme Unipac-PE-60 não irradiado, oito dias e dois meses após a irradiação e o seu valor limite de segurança (Unipac-PE-60 >19,29 MPa), estabelecido pelo fabricante para a sua comercialização.

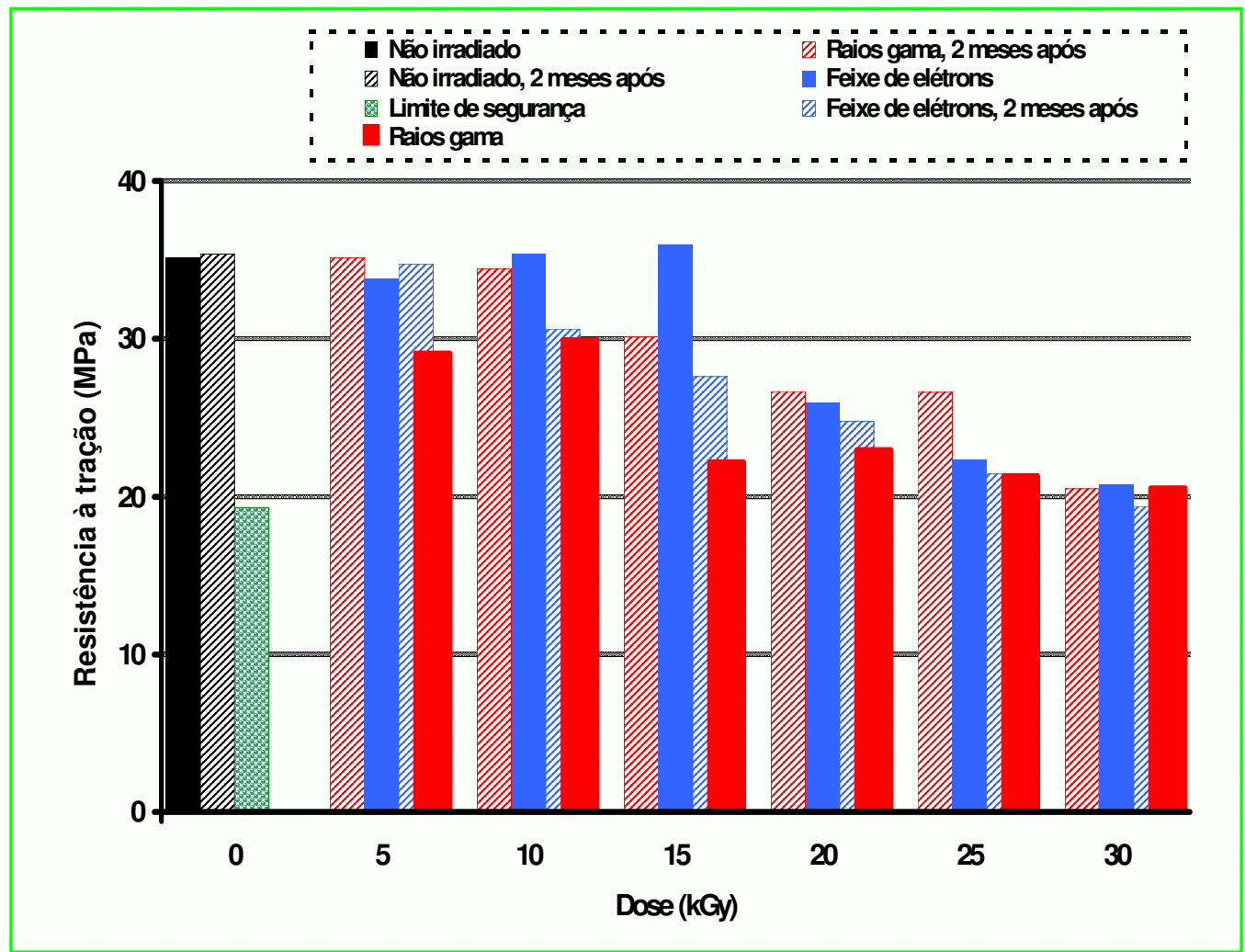

FIGURA 28 - Comparação entre os valores da resistência à tração do filme Unipac-PE-60, não irradiado, oito dias e dois meses após a irradiação com raios gama ou com feixe de elétrons e o seu valor limite de segurança.

Pode-se observar na FIG.28, uma redução com o aumento da dose de radiação, nas características originais de resistência à tração do filme Unipac-PE60 , irradiado com raios gama ou com feixe de elétrons, mesmo decorridos dois meses da irradiação. Esta redução torna-se mais evidente a partir da dose de 10 kGy, principalmente para as amostras irradiadas com feixe de elétrons. Nota-se também, que apesar da sensível queda nos valores médios de resistência às solicitações de tração do filme irradiado, estes mantém-se ainda, muito acima do seu valor "limite de segurança". 
Com relação a estrutura Lovaflex $\mathrm{CH} 130$ irradiada com raios gama ou com feixe de elétrons, os ensaios de resistência à tração, realizados oito dias após a irradiação (FIG.29), mostraram :

a) Ganhos na sua resistência à tração original (filme não irradiado), para as amostras irradiadas com raios gama, nas doses de radiação de até 15 kGy (atingindo cerca de $10 \%$ para a dose de $10 \mathrm{kGy}$ ) e redução de $2 \%$ na dose de $20 \mathrm{kGy}$. Nas doses de 25 e $30 \mathrm{kGy}$ os valores registrados foram ligeiramente maiores que o original;

b) Perdas na sua resistência à tração original, em todo o intervalo de dose de radiação estudado, para as amostras irradiadas com feixe de elétrons.

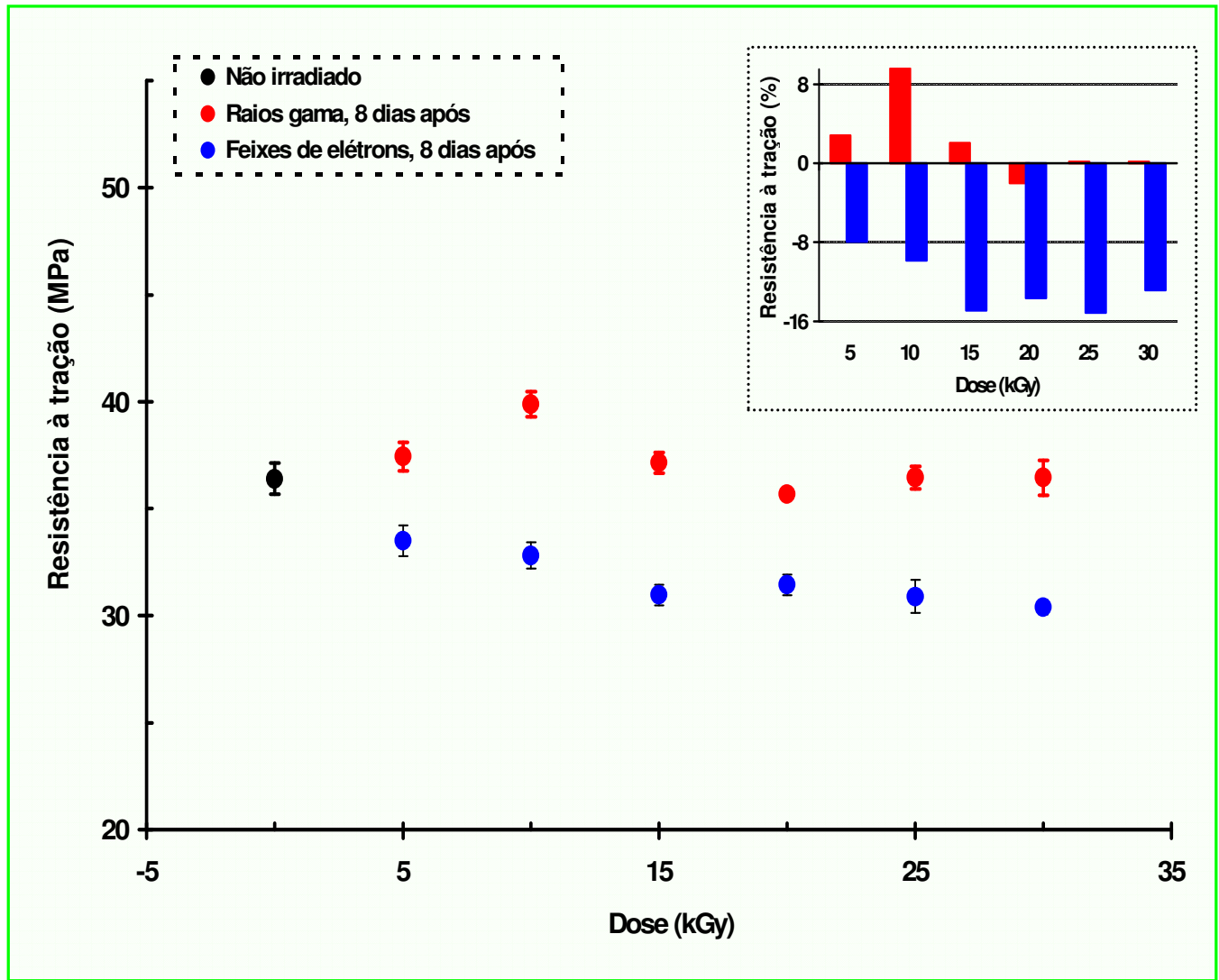

FIGURA 29 - Resistência à tração no ponto de ruptura em função da dose de radiação para a estrutura Lovaflex $\mathrm{CH}$ 130, oito dias após a irradiação com raios gama ou com feixe de elétrons. 
Na FIG. 30 é mostrado o comportamento da resistência à tração no ponto de ruptura da estrutura Lovaflex $\mathrm{CH}$ 130, dois meses após a irradiação com raios gama ou com feixe de elétrons.

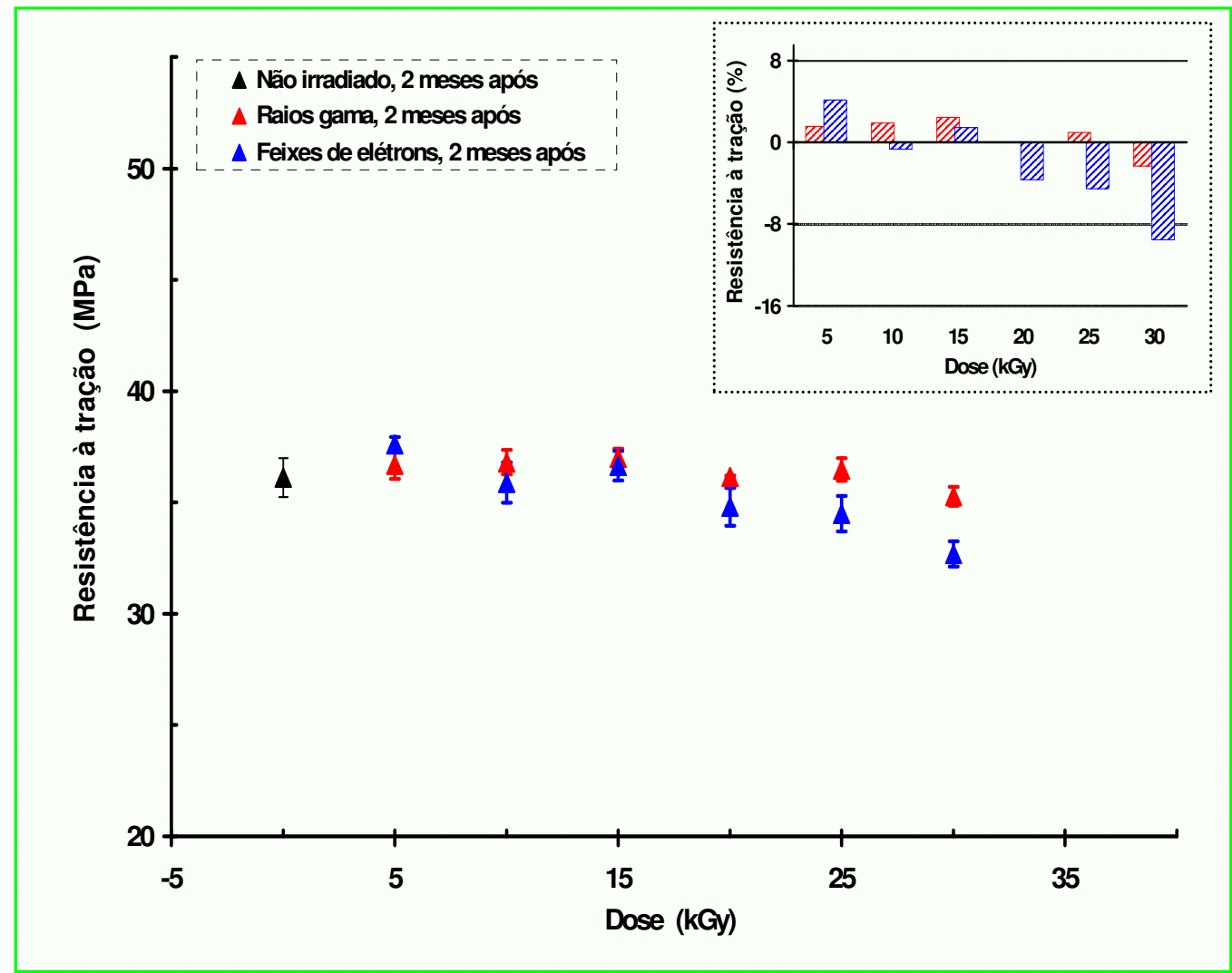

FIGURA 30 - Resistência à tração no ponto de ruptura em função da dose de radiação para a estrutura Lovaflex $\mathrm{CH}$ 130, 2 meses após a irradiação com raios gama ou com feixe de elétrons.

Com relação aos ensaios de tração realizados na estrutura Lovaflex $\mathrm{CH}$ 130, dois meses após a irradiação, pode-se observar na FIG.30 que:

a) A resistência à tração é maior que a original (filme não irradiado) para as doses de radiação com raios gama de até 15 kGy e para a dose de 25 kGy (atingindo cerca de 2,5\% para a dose de $15 \mathrm{kGy}$ ). Na dose de $30 \mathrm{kGy}$ a sua resistência à tração é menor que a original (cerca de 2,5\%);

b) Nas irradições com feixe de elétrons a resistência à tração é maior que a original para as doses de radiação de 5 e 15 kGy (atingindo cerca de 4,0\% 
para a dose de $5 \mathrm{kGy}$ ) e diminuiu com o aumento da dose de radiação no intervalo de dose entre 20 e 30 kGy, atingindo a sua redução máxima para a dose de 30 kGy (cerca de 10\%).

Nos diagramas de barras, em detalhe no canto direito das FIG. 29 e 30, são apresentadas as variações percentuais da resistência à tração no ponto de ruptura da estrutura Lovaflex $\mathrm{CH}$ 130, oito dias após a irradiação (FIG.29) e dois meses após a irradiação (Fig.30).

Na FIG.31 é apresentada uma comparação entre os valores da resistência à tração da estrutura Lovaflex $\mathrm{CH} 130$ não irradiada, oito dias após a irradiação e decorrido dois meses, e o seu valor limite de segurança (Lovaflex CH 130 > 19,14 MPa), estabelecido pelo fabricante para a sua comercialização.

Pode-se observar na FIG.31 que decorridos dois meses da irradiação a resistência às solicitações de tração da estrutura Lovaflex $\mathrm{CH}$ 130, irradiada com raios gama não apresentou mudanças drásticas, quando comparada a original. Observa-se que os valores médios de resistência à tração encontram-se muito próximos ao seu valor original (filme não irradiado), independentemente da dose de radiação gama aplicada, apresentando ligeira oscilação para mais ou para menos. Nas irradiações com feixe de elétrons, decorridos dois meses da irradiação, os valores médios da resistência às solicitações de tração do filme irradiado apresentaram maiores desvios da original, para algumas doses de radiação. Observa-se também na mesma figura um ganho de resistência para as amostras do Lovaflex $\mathrm{CH} 130$ irradiadas com feixe de elétrons na dose de 5 kGy (cerca de 4\%) e perda para as amostras irradiadas com doses de 20 a 30 kGy (redução da ordem de 4 a 10\%). Embora o Lovaflex $\mathrm{CH} 130$ irradiado com feixe de elétrons tenha apresentado uma redução de até $10 \%$ no valor da sua resistência à tração original, esta ainda se mantém muito acima do seu valor "limite de segurança". 


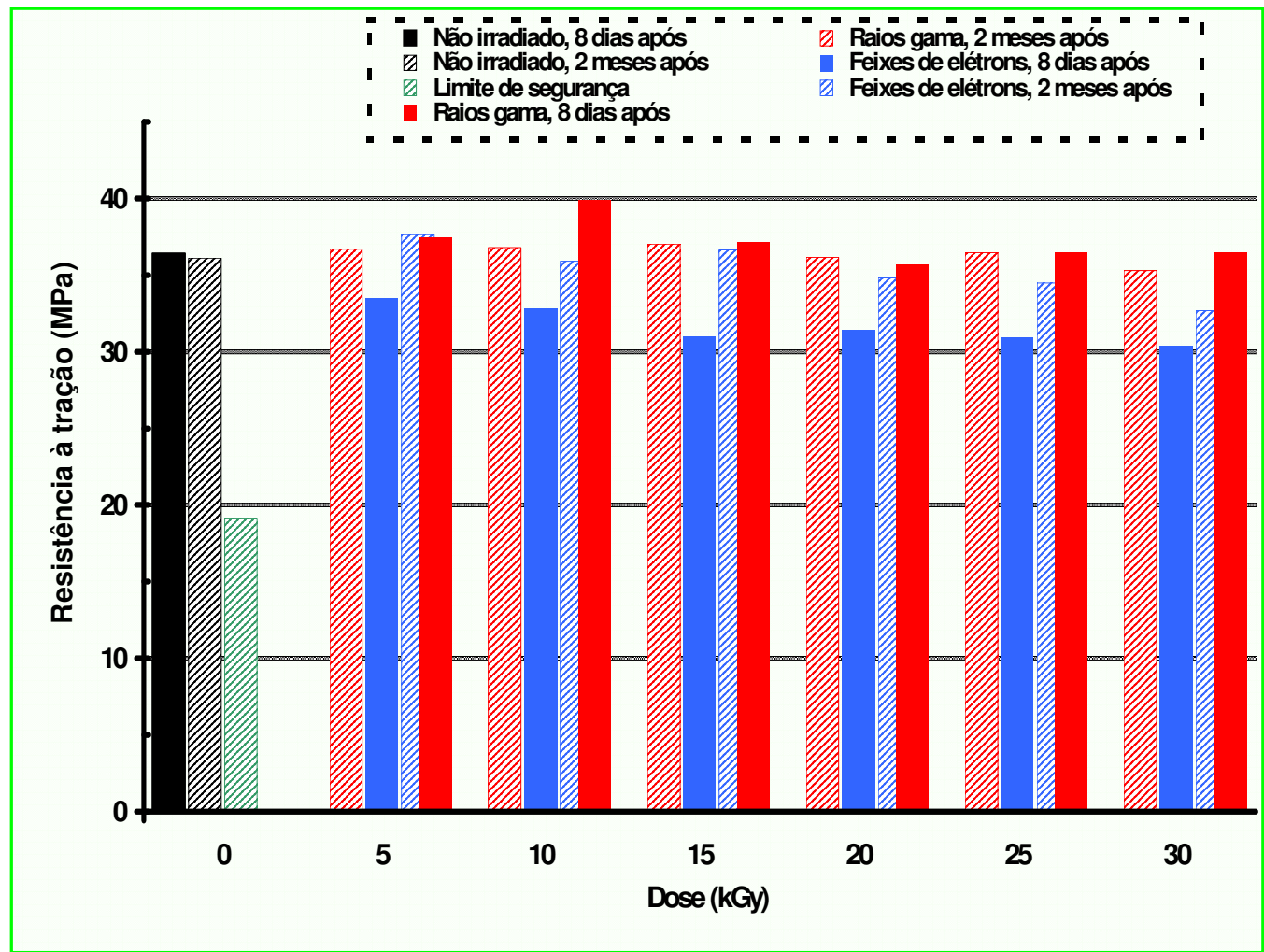

FIGURA 31 - Comparação entre os valores da resistência à tração da estrutura Lovaflex $\mathrm{CH}$ 130, não irradiada, oito dias e dois meses após a irradiação com raios gama ou com feixe de elétrons e o seu valor limite de segurança.

\subsubsection{Porcentagem de alongamento na ruptura}

Nas FIG.32 e 33 são mostradas as porcentagens de alongamento na ruptura em função da dose de radiação para o filme Unipac PE 60 irradiado com raios gama ou com feixe de elétrons.

Com relação ao filme Unipac-PE-60, observa-se, nos ensaios realizados oito dias após a irradiação (Fig.32):

a) Redução na sua porcentagem de deformação original com o aumento da dose de radiação com raios gama; 
b) Aumento na sua porcentagem de deformação original para as doses de radiação com feixe de elétrons entre 5 e 15 kGy e uma redução a partir de 20 kGy.

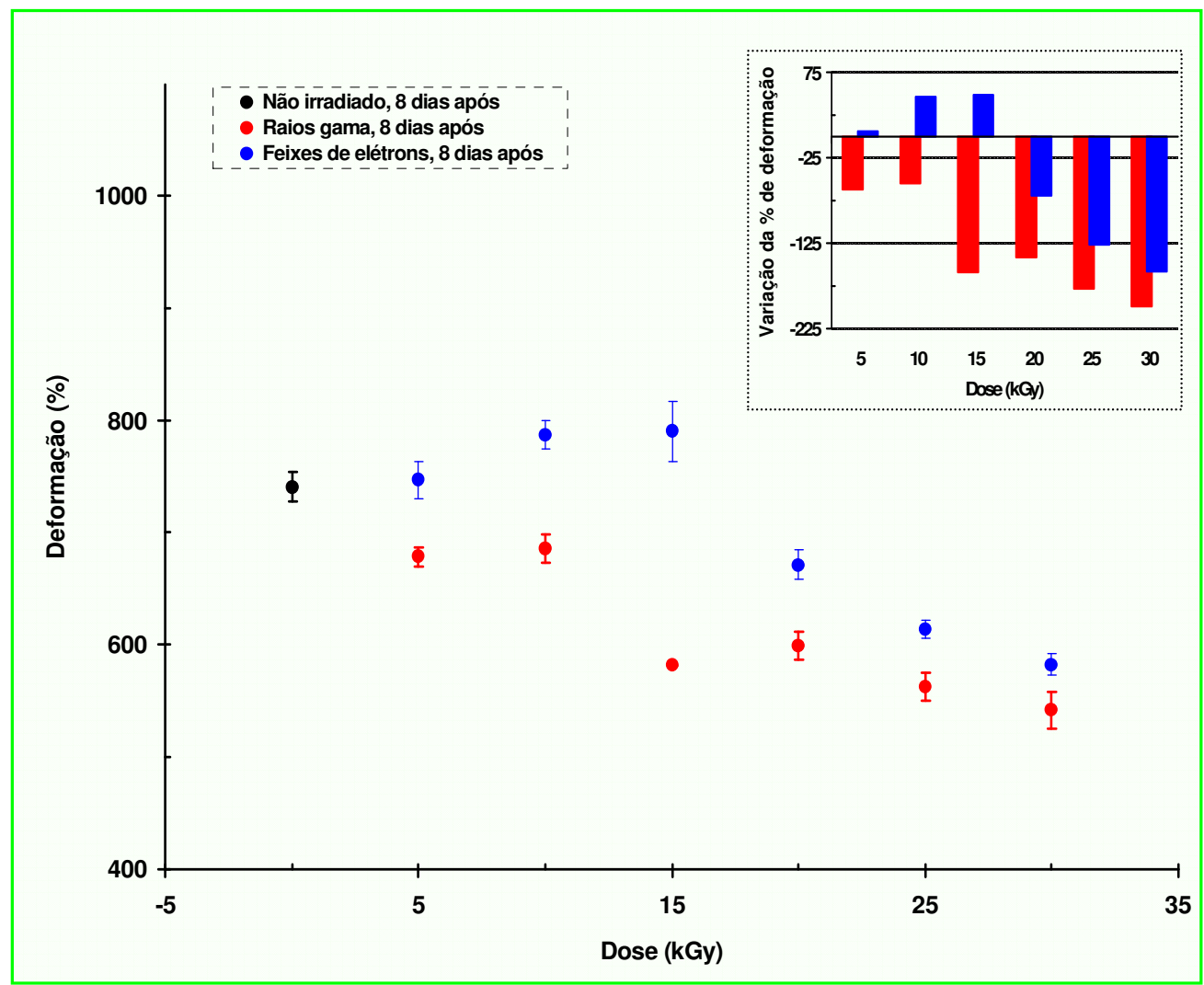

FIGURA 32 - Porcentagem de deformação em função da dose de radiação para o filme Unipac-PE-60 oito dias após a irradiação com raios gama ou com feixe de elétrons.

Nos ensaios realizados dois meses após a irradiação (FIG.33), pode-se observar que a sua porcentagem de deformação original aumentou com o a dose de radiação com raios gama, no intervalo de dose de radiação entre 5 e 20 kGy ou com feixe de elétrons, para 5 e 15 kGy. 


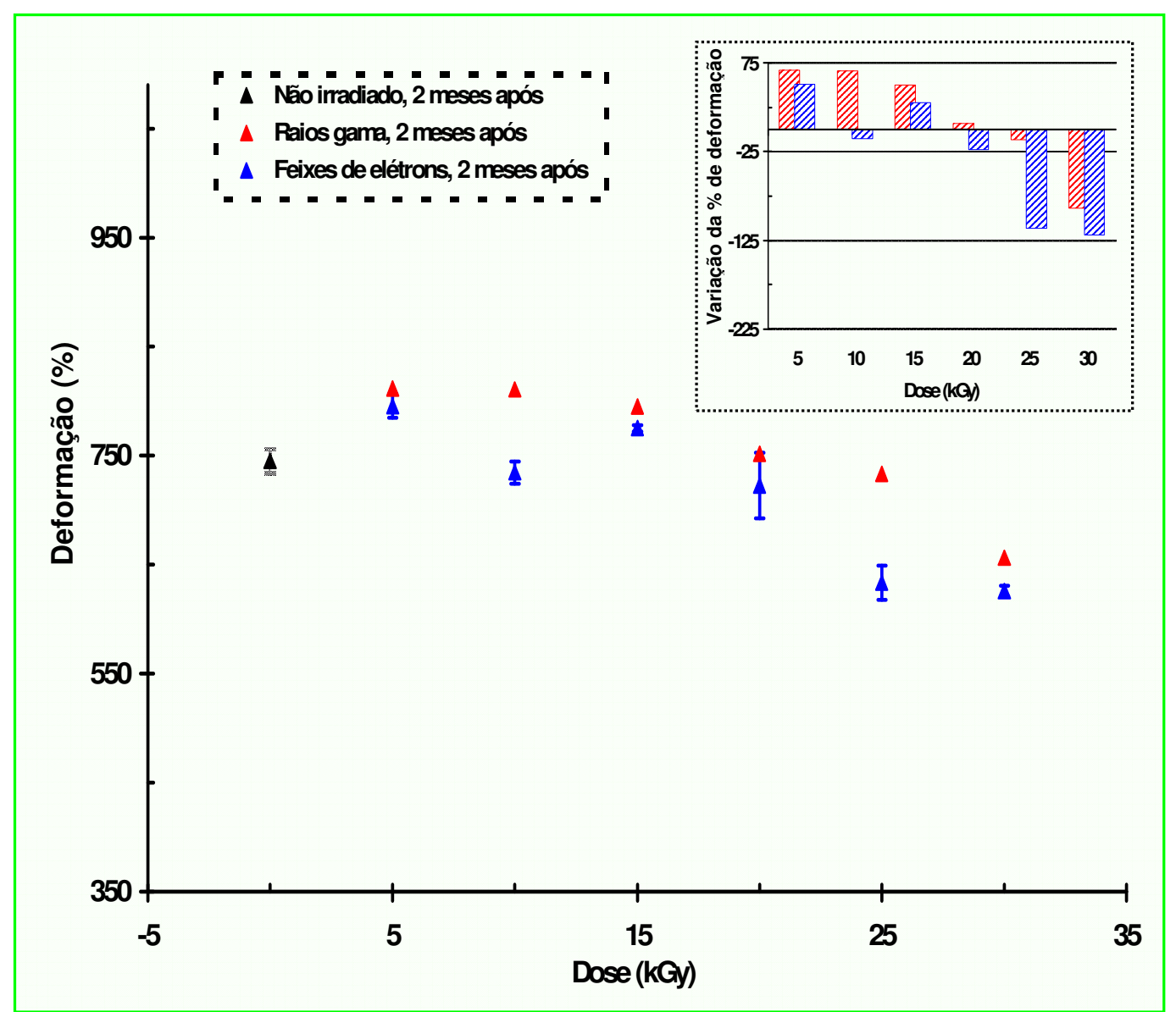

FIGURA 33 - Porcentagem de deformação em função da dose de radiação para o filme Unipac-PE-60 dois meses após a irradiação com raios gama ou com feixe de elétrons.

Nos diagramas de barras, em detalhe no canto direito das FIG. 32 e 33, estão representadas as variações na porcentagem de alongamento do Unipac-PE60, oito dias após a irradiação (FIG.32) e dois meses após a irradiação (Fig.33).

Na FIG.34 é apresentada uma representação gráfica da variação das porcentagens de alongamento do filme Unipac-PE-60 oito dias após a irradiação e decorrido dois meses da irradiação com raios gama ou com feixe de elétrons, em relação a sua deformação original. Pode-se observar na FIG.34 que decorridos dois meses da irradiação, o filme irradiado com feixe de elétrons com doses de radiação de 10 kGy e a partir de 20 kGy e com raios gama a partir de 25 kGy, 
apresentou redução da sua deformação elástica orginal. Observa-se também, que decorridos dois meses da irradiação, ocorreu um ganho de deformação elástica para as amostras irradiadas com raios gama nas doses de até 20 kGy e nas doses de 5 e 15 kGy para as irradiações com feixe de elétrons.

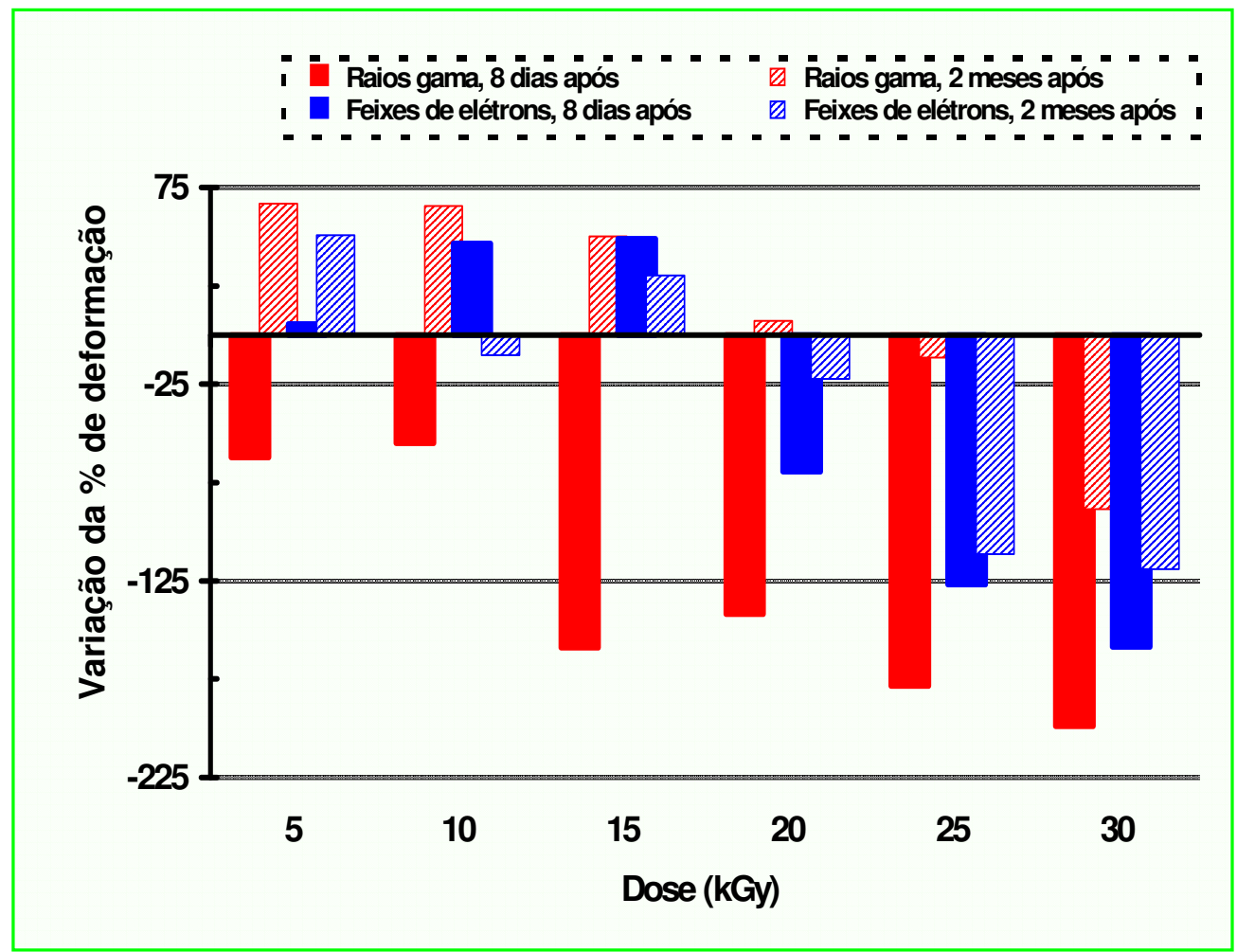

FIGURA 34 - Variação da porcentagem de deformação original do filme UnipacPE-60, em função da dose de radiação, oito dias e dois meses após a irradiação com raios gama ou com feixe de elétrons.

Nas FIG. 35 e 36 são mostradas as porcentagens de deformação em função da dose de radiação para a estrutura Lovaflex $\mathrm{CH}$ 130, irradiada com raios gama ou com feixe de elétrons.

Com relação a estrutura Lovaflex $\mathrm{CH}$ 130, observou-se nos ensaios realizados oito dias após a irradiação (FIG. 35), redução na sua deformação elástica original, tanto para as irradiações com raios gama como para com feixe de elétrons. 


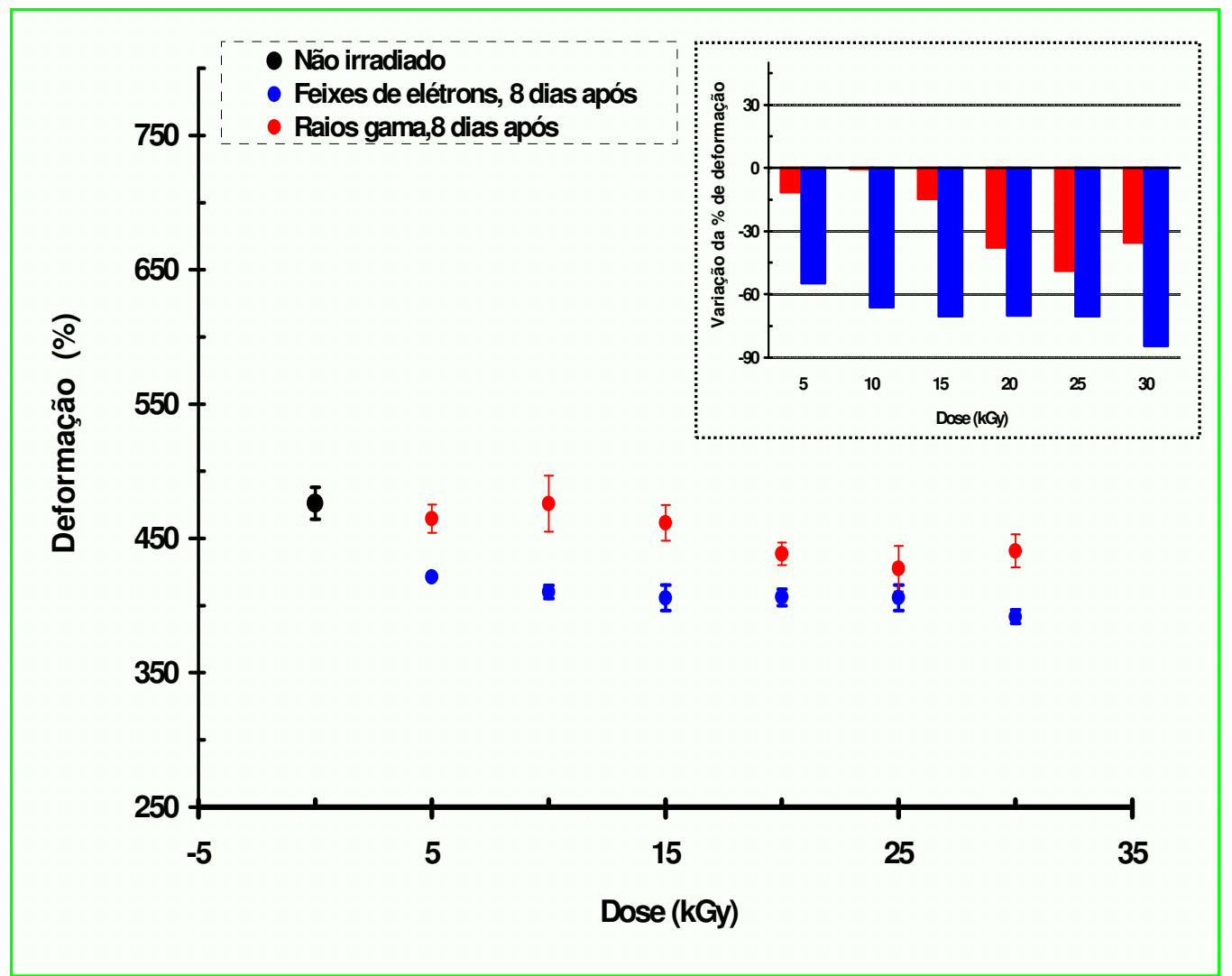

FIGURA 35 - Porcentagem de alongamento no ponto de ruptura em função da dose de radiação para a estrutura Lovaflex $\mathrm{CH} 130$ oito dias após a irradiação com raios gama ou com feixe de elétrons.

Nos ensaios realizados dois meses após a irradiação (FIG.36), a estrutura Lovaflex apresentou ganho na sua deformação elástica original com o aumento da dose de radiação. Observa-se que nas irradiações com raios gama o ganho na deformação predominou para as doses de radiação de até 15 kGy e nas irradiações com feixe de elétrons para as doses de radiação de até 25 kGy.

Nos diagramas de barras, em detalhe no canto direito das FIG. 35 e 36, estão representadas as variações na porcentagem de alongamento do Lovaflex $\mathrm{CH}$ 130, oito dias após a irradiação (FIG.35) e dois meses após a irradiação (FIG.36). 


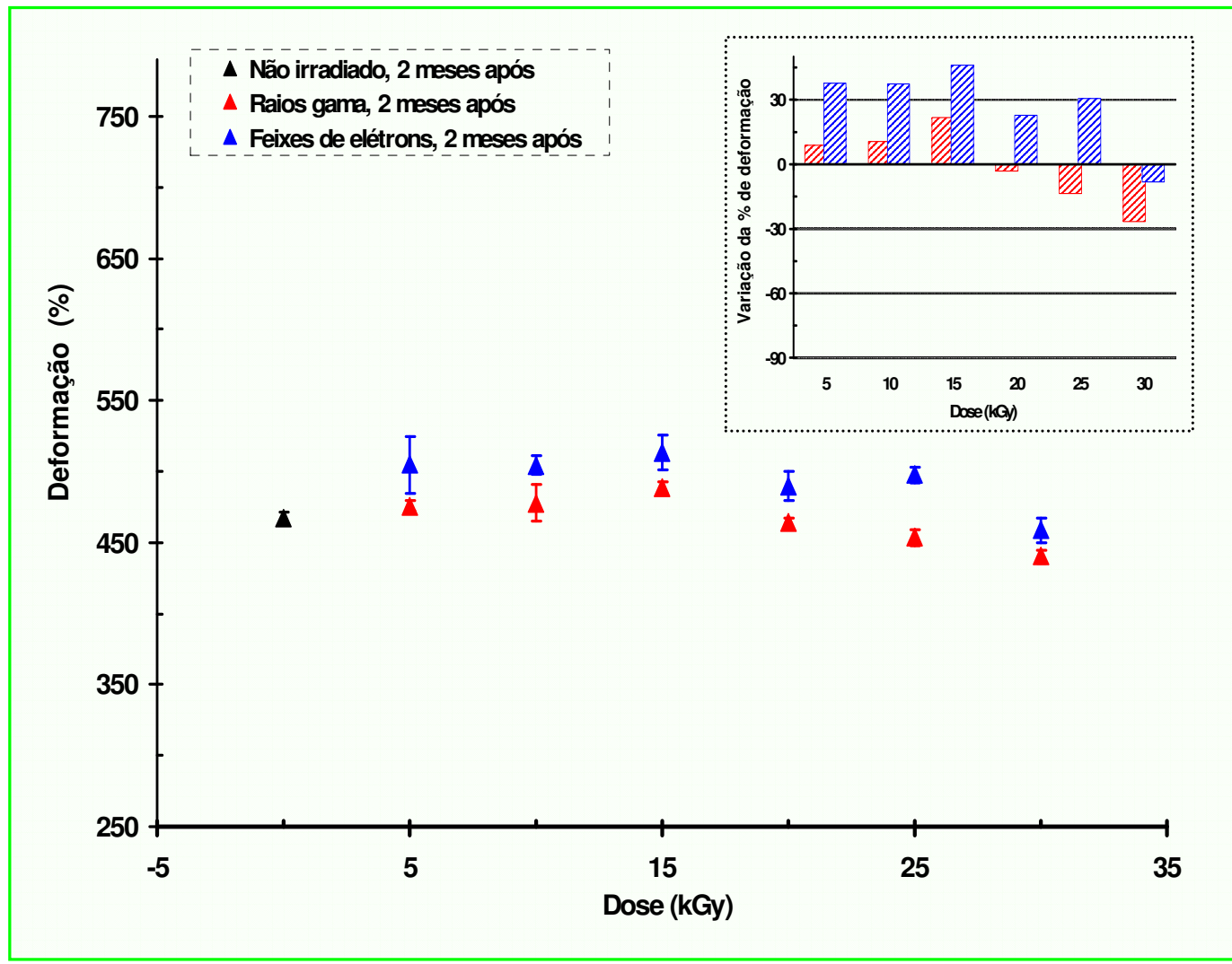

FIGURA 36 - Porcentagem de deformação em função da dose de radiação para a estrutura Lovaflex $\mathrm{CH} 130$ dois meses após a irradiação com raios gama ou com feixe de elétrons.

Na FIG.37 é apresentada uma representação gráfica da variação das porcentagens de alongamento da estrutura Lovaflex $\mathrm{CH} 130$ oito dias após a irradiação e decorrido dois meses da irradiação com raios gama ou com feixe de elétrons, em relação a sua deformação original. Pode-se observar na FIG.37 que o Lovaflex CH 130 apresentou após a irradiação redução da sua deformação elástica orginal. Observa-se também, que decorridos dois meses da irradiação, ocorreu um ganho na deformação elástica do filme para as amostras irradiadas com raios gama nas doses de até 15 kGy e nas doses de até 25 kGy para as irradiações com feixe de elétrons. 


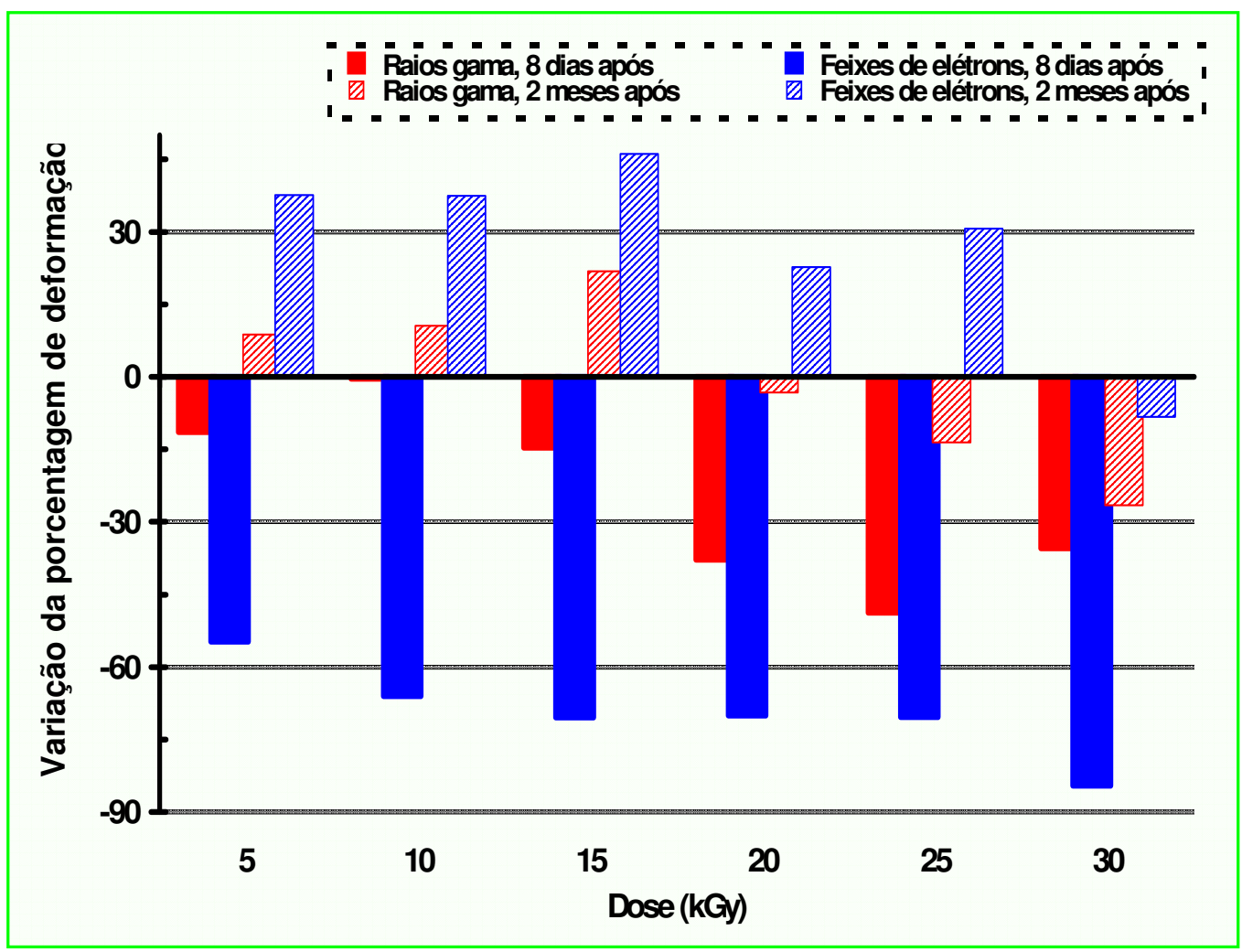

FIGURA 37 - Variação da porcentagem de deformação original para a estrutura Lovaflex CH 130 irradiada em função da dose de radiação, oito dias e dois meses após a irradiação com raios gama ou com feixe de elétrons.

Os resultados observados nos ensaios mecânicos de tração, mostrados nas FIG. 26 a 37, sugerem que os processos de degradação predominaram sobre os processos de reticulação tanto para o filme Unipac-PE-60 como para o Lovaflex $\mathrm{CH}$ 130. Goulas e colaboradores ${ }^{[17]}$, observaram um comportamento semelhante, ao estudarem o efeito das doses de radiação gama de até 30 kGy nas propriedades mecânicas de tração e deformação, das estruturas coextrusadas LDPE/EVOH/LDPE e PA/LDPE.

Durante a irradiação de materiais poliméricos, pode ocorrer, paralelamente a degradação e a reticulação, a formação de ligações insaturadas, formação de gases e de produtos de massa molar baixa gerados pela radiólise ${ }^{[67-74]}$. Assim, vários fatores podem ter contribuído para as alterações 
observadas na resistências às solicitações de tração e deformação elástica destes filmes, tais como:

> Presença de degradação oxidativa, em razão das reações entre os radicais livres produzidos pela irradiação e o oxigênio presente, uma vez que as irradiações foram realizadas na presença de ar ${ }^{[69-71]}$;

> Quando a irradiação é realizada nas condições atmosféricas normais, ou seja na presença de ar, a degradação oxidativa se dá com maior intensidade em polímeros sob a forma de fibras ou filmes, nos quais o oxigênio se difunde mais facilmente $e^{[68,69]}$;

> Embora seja conhecido que as reações de reticulação são dominantes durante a irradiação de polietileno (PE) com radiação ionizante, o Unipac-PE-60 é um filme da extrusão de LDPE, o qual entre os PE é o que apresenta menor resistência à radiação ${ }^{[58,69,71]}$;

> Como as irradiações foram realizadas na presença de ar, nas irradiações com raios gama, como a taxa de dose foi muito baixa, quando comparada a irradiação com feixe de elétrons, (3,48-4,43 kGy/h para gama; 11,22 kGy/s para elétrons), as reações secundárias de oxidação devem ter sido favorecidas, o que provavelmente gerou uma maior formação de espécies radicalares, as quais continuaram reagindo com o oxigênio presente até a sua recombinação por meio de uma reação de terminação ${ }^{[69-72]}$.

> Os aditivos antioxidantes fenólicos e fosfitos, geralmente presentes em polímeros poliolefínicos, sofrem preferencialmente degradação nos processos de irradiação por causa da radiólise parcial. A resina de LDPE, produzida para as aplicações de embalagens flexíveis, contém em sua formulação antioxidantes fenólicos como o Irganox 565 e fosfitos como o Irgafos 168. Os aditivos deslizantes, anti-bloqueio e anti-estático, utilizados nestes filmes, são também mais sensíveis as condições de irradiação e mais suscetíveis a

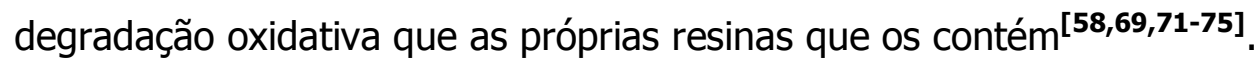

> O EVOH presente na estrutura Lovaflex apresenta, baixa resistência à radiação ionizante. Esta resina quando submetida à radiação sofre, preferencialmente 
degradação, conforme informação pessoal do fornecedor, a qual foi confirmada neste trabalho.

As PAs apresentam resistência média à radiação ionizante com respeito as mudanças nas propriedades mecânicas, como mostram os trabalhos de Clough e colaboradores ${ }^{[57]}$.

\subsection{Ensaios mecânicos de resistência à perfuração}

Nas Figuras 38 e 39 são mostrados o comportamento da resistência à perfuração em função da dose de radiação para os filmes Unipac PE 60 e Lovaflex $\mathrm{CH} 130$ irradiados com raios gama ou com feixe de elétrons.

Pode-se observar na FIG. 38 ganhos na resistência à perfuração original do filme Unipac-PE-60 irradiado com raios gama nas doses de radiação entre 0 e 15 kGy e para a dose de radiação de 30 kGy. Para as amostras do filme irradiadas com feixe de elétrons observa-se ganhos em praticamente todo o intervalo de dose estudado, exceto para a dose de radiação de 15 kGy, onde o valor médio de resistência à perfuração do filme irradiado é menor que a resistência à perfuração do filme original. Nota-se na mesma figura redução da sua resistência à perfuração original para o filme irradiado com doses de radiação gama de 20 e 25 kGy. No diagrama de barras, em detalhe no canto direito da FIG. 38 estão representadas as variações percentuais da resistência à perfuração original do Unipac-PE-60 após a irradiação com raios gama ou com feixe de elétrons. Pode-se observar nesse diagrama ganhos percentuais da ordem de 10 a $15 \%$ para o filme irradiado com raios gama (dose entre 5 e $15 \mathrm{kGy}$ e $30 \mathrm{kGy}$ ) e da ordem de 5 a $19 \%$ para as irradiações com feixe de elétrons exceto para a dose de 15 kGy. Observa-se também nessa figura reduções em cerca de 5 a $7 \%$ para as irradiações com raios gama (doses de 20 e 25 kGy) e menor que $1 \%$ para feixe de elétrons (dose de $15 \mathrm{kGy}$ ). 


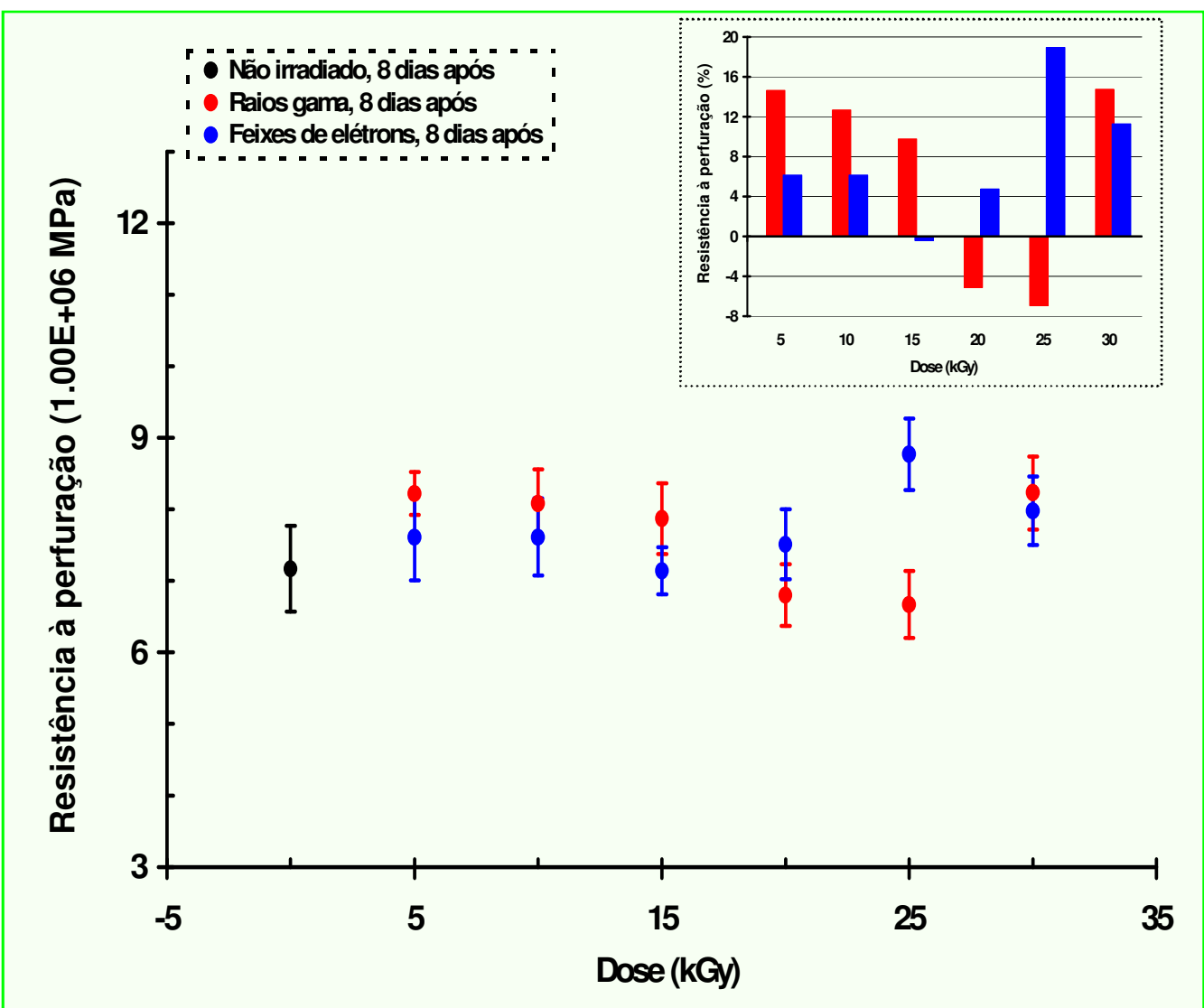

FIGURA 38 - Resistência à pefuração para o filme Unipac-PE-60 em função da dose de radiação com raios gama ou com feixe de elétrons.

Com relação a estrutura Lovaflex CH 130 (FIG. 39), pode-se observar ganhos na resistência à perfuração original da estrutura Lovaflex $\mathrm{CH} 130$ irradiada com raios gama nas doses de radiação entre 10 e 25 kGy e redução nas dose de radiação de 5 e $30 \mathrm{kGy}$. Para o filme irradiado com feixe de elétrons observa-se ganhos apenas para as doses de radiação de 20 e 30 kGy e redução nas demais doses.

No diagrama de barras, em detalhe no canto direito da FIG. 39 estão representadas as variações percentuais da resistência à perfuração original da estrutura Lovaflex $\mathrm{CH} 130$ irradiada com raios gama ou com feixe de elétrons. Pode-se observar nesse diagrama ganhos percentuais da ordem de 5 a $9 \%$ para as amostras do filme irradiadas com raios gama (doses entre 10 e $25 \mathrm{kGy}$ ) e de 
cerca de 1 a 2\% para as doses de 30 e 25 kGy com feixe de elétrons, respectivamente. Observa-se também reduções percentuais na sua resistência à perfuração original em cerca de 2,5 a 4,5\% para as irradiações com raios gama (doses de 5 e $30 \mathrm{kGy}$ ) e da ordem de 4,0 a 7,0\% para feixe de elétrons (doses entre 5 e 15 kGy).

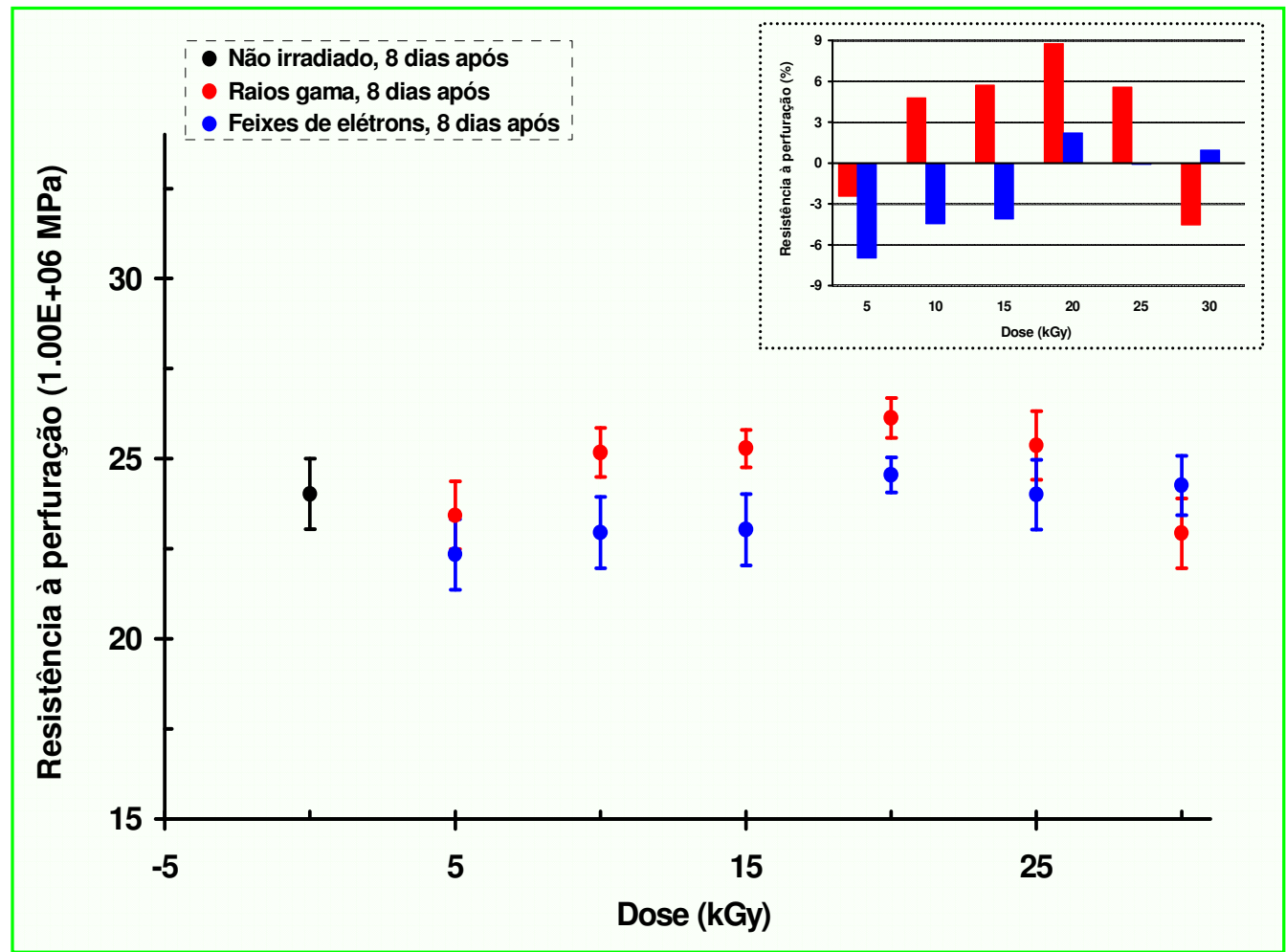

FIGURA 39 - Resistência à pefuração para a estrutura Lovaflex $\mathrm{CH} 130$ em função da dose de radiação com raios gama ou com feixe de elétrons

As alterações observadas nas FIG.38 e 39 sugerem a redução da distância entre as cadeias macromoleculares dos materiais irradiados para algumas doses de radiação, por exemplo, nas doses de radiação gama entre 10 e 25 kGy para a estrutura Lovaflex CH 130 e aumento da distância entre as cadeias macromoleculares para outras doses de radiação, especialmente nas doses de radiação com feixe de elétrons entre 5 e 15 kGy (FIG.39). As variações na distância entre as cadeias macromoleculares das amostras do filme Unipac-PE-60 e da estrutura Lovaflex $\mathrm{CH} 130$ irradiadas podem ter ocorrido em razão dos 
rearranjos sofridos pelas macromoléculas em função dos processos de degradação e reticulação por radiação. Possivelmente uma maior contribuição da degradação oxidativa e da cisão das cadeias poliméricas, resultando em cadeias menores e estrutura polimérica mais organizada.

\subsection{Análises de UV/Vis}

Nas FIG.40 e 41 são mostradas as intensidades de absorção de luz para o filme Unipac-PE-60 irradiado com raios gama ou com feixe de elétrons oito dias após a irradiação. Cada espectro final apresentado representa a média de quatro amostras de igual tamanho e espessura, obtidas aleatoriamente a partir das amostras dos filmes irradiadas e não irradiadas.

Com relação ao filme Unipac-PE-60 irradiado com raios gama (FIG.40), pode-se observar nos espectros de absorbância obtidos oito dias após a irradiação, que a partir do limite de corte UV (cut-off para UV/Vis, ou seja, comprimento de onda em que a absorbância aumenta repentinamente para valores altos; $200 \mathrm{~nm}$ ), ocorreu um deslocamento em direção à região do comprimento de onda do vermelho e formação de uma cauda de absorção para os espectros das amostras do filme Unipac-PE-60 irradiadas com doses de radiação maiores que $10 \mathrm{kGy}$. O deslocamento é maior na região de comprimento de onda entre 215-250 nm e para o intervalo de dose de radiação entre 15 e 30 kGy, além disso, os materiais irradiados correspondentes apresentaram ligeiro amarelecimento.

Observa-se também na FIG.40 que, a partir do comprimento de onda de 250 nm, as respostas do material à radiação gama são semelhantes para as doses de radiação de até $20 \mathrm{kGy}$. Na dose de radiação de 25 kGy a intensidade de absorção das amostras do filme irradiadas é maior que a intensidade de absorção original (filme não irradiado) até a região de comprimento de onda de $270 \mathrm{~nm}$ e para a dose de 30 kGy esta é maior até o comprimento de onda de $315 \mathrm{~nm}$. 


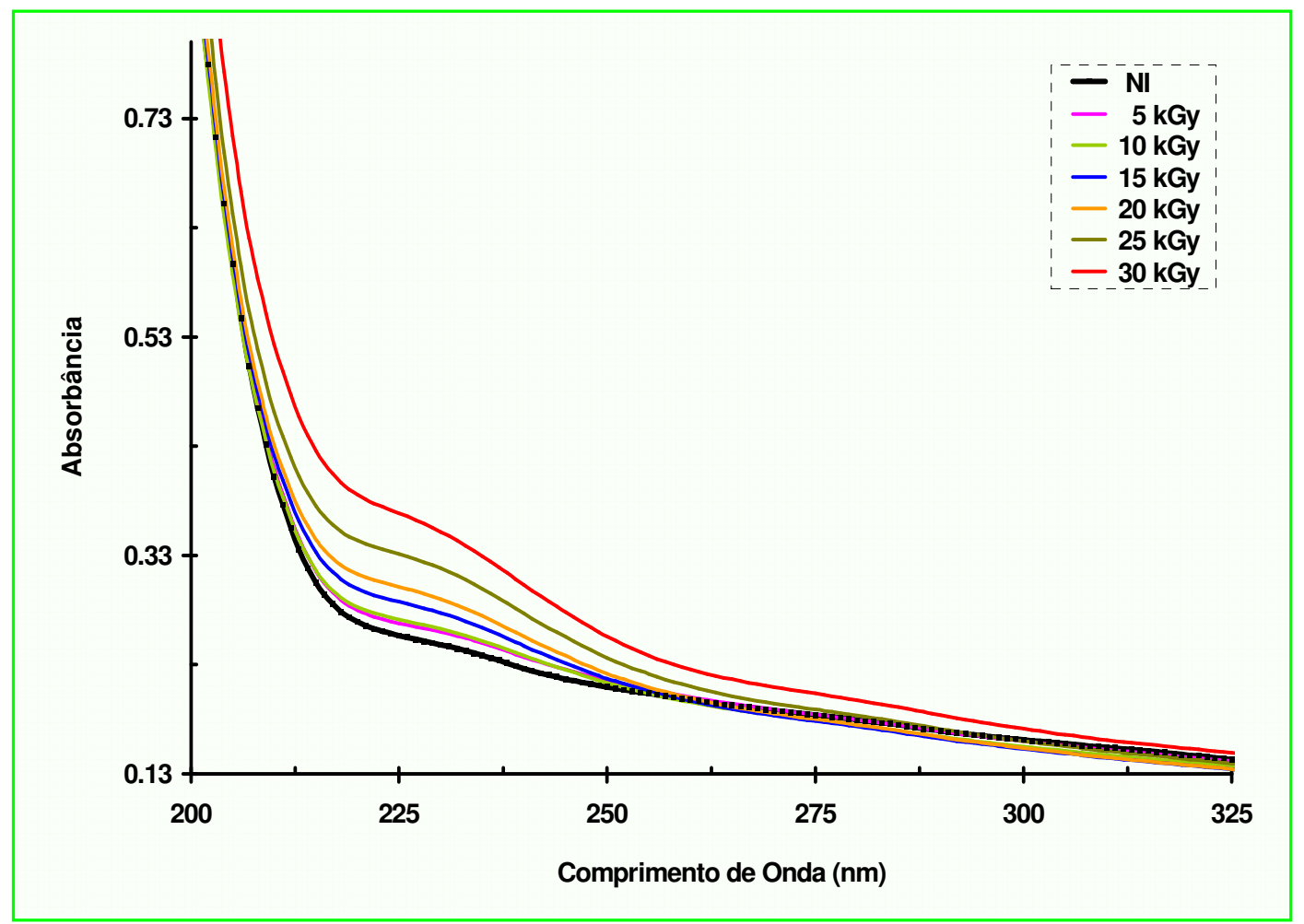

FIGURA 40 - Espectros de absorbância para o filme Unipac-PE-60 oito dias após irradiação com raios gama, no intervalo de dose de radiação entre 0 - 30 kGy.

Com relação ao filme Unipac-PE-60 irradiado com feixe de elétrons (FIG.41), as alterações ocorrem na mesma região do espectro de energia observada para as irradiações com raios gama $(215-250 \mathrm{~nm})$, porém a sua intensidade é maior. Para as amostras irradiadas com doses maiores que $10 \mathrm{kGy}$, observa-se, a partir do "UV- cut-off" um deslocamento em direção à região do vermelho e formação de uma cauda de absorção. O deslocamento é maior para o intervalo de dose de radiação entre 15-30 kGy na região de comprimento de onda de 215 a $250 \mathrm{~nm}$ e as amostras irradiadas correspondentes apresentaram ligeiro amarelecimento. A partir de $250 \mathrm{~nm}$, não são observadas diferenças entre a intensidade de absorção do filme original (filme não irradiado) e o irradiado. $\mathrm{Na}$ região de comprimento de onda de $220 \mathrm{~nm}$, onde a intensidade de absorção do filme irradiado atinge o seu máximo, a intensidade de absorbância medida no filme irradiado com feixe de elétrons é cerca de 7 a $36 \%$ maior que a do filme irradiado com raios gama. 


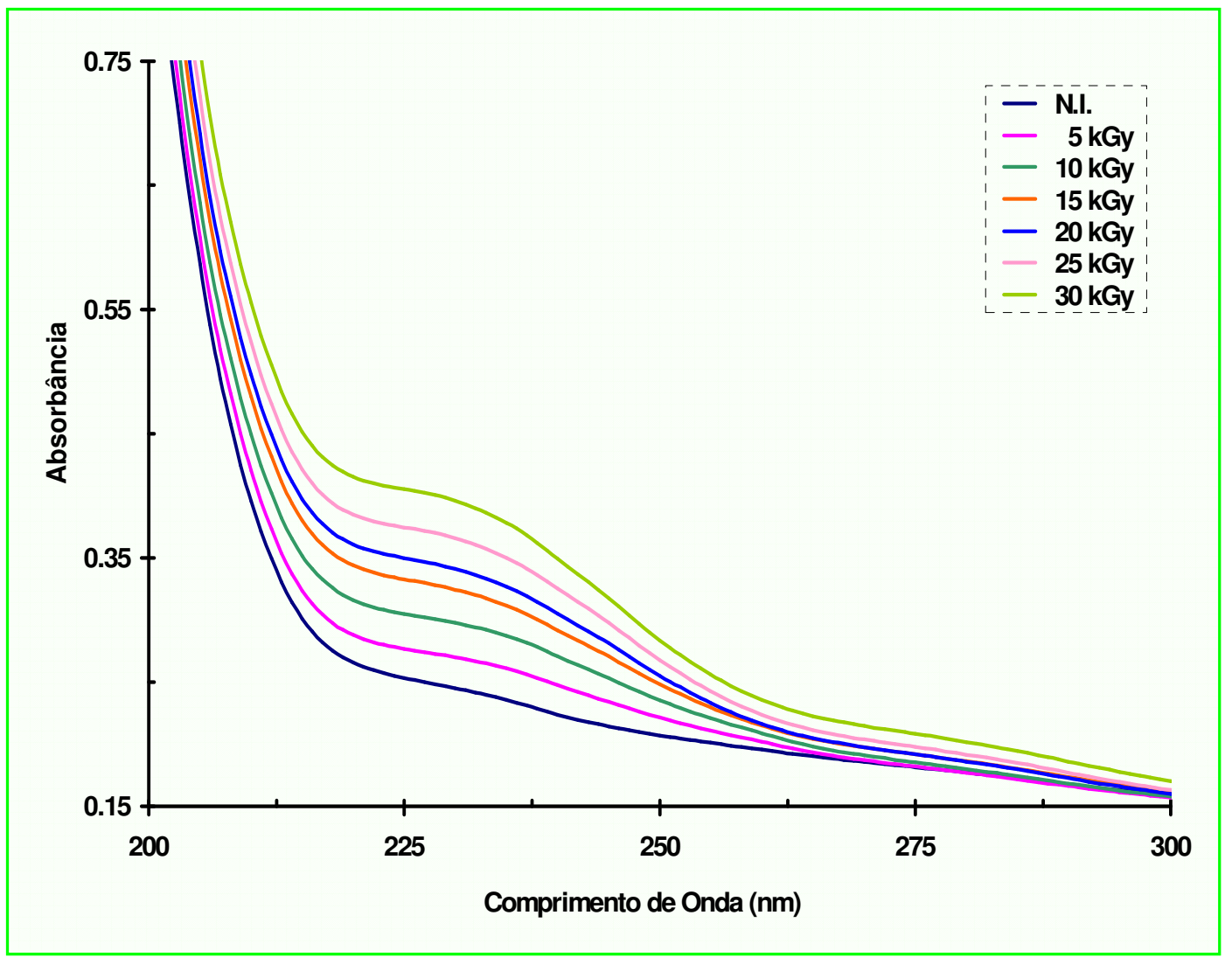

FIGURA 41 - Espectros de absorbância para o filme Unipac-PE-60 oito dias após irradiação com feixe de elétrons, no intervalo de dose de radiação entre 0 - 30 kGy.

Nas FIG.42 e 43 são mostradas a intensidade de absorção de luz para o filme Lovaflex CH 130 irradiado com raios gama (FIG.42) ou com feixe de elétrons (FIG.43) oito dias após a irradiação. Cada espectro final apresentado representa a média de quatro amostras de igual tamanho e espessura, obtidas aleatoriamente a partir das amostras dos filmes irradiadas e não irradiadas.

Com relação a estrutura Lovaflex $\mathrm{CH}$ 130, observa-se um deslocamento a partir do limite de corte UV (cut-off para UV/Vis, 233 nm nas FIG.42 e 43) em direção à região do comprimento de onda do vermelho e formação de uma cauda de absorção, à semelhança do que se observa com o filme UNIPAC-PE-60. Entretanto, neste caso o deslocamento é maior na região do espectro de 245-280 
$\mathrm{nm}$, para as irradiações com raios gama em doses de até 25 kGy e de 245-300 nm para a dose de radiação gama de 30 kGy (Fig.42).

Na região de comprimento de onda entre 300 - $600 \mathrm{~nm}$ a estrutura Lovaflex CH 130 irradiada com raios gama apresenta intensidades de absorbância inferior a apresentada pelo original.

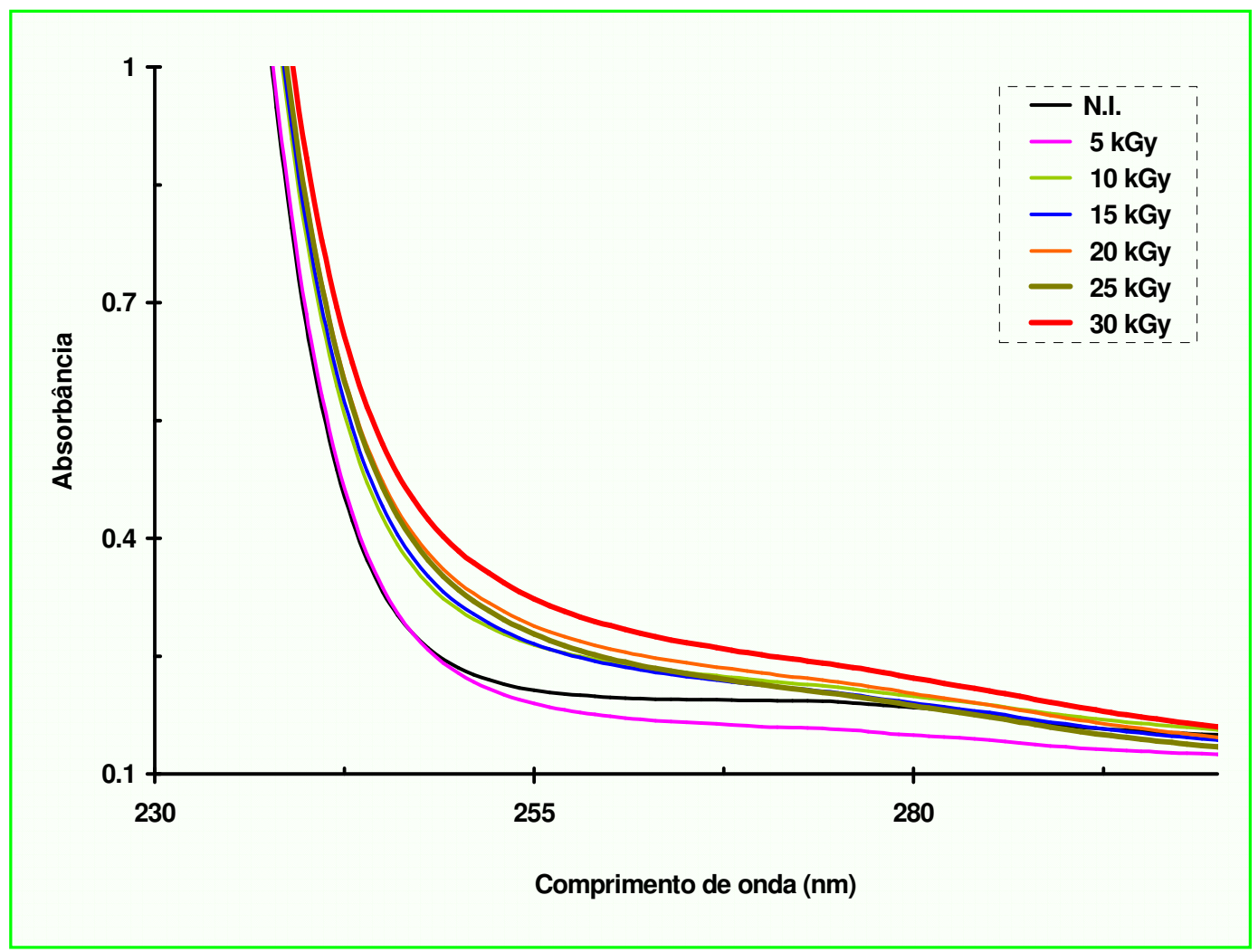

FIGURA 42 - Espectros de absorbância para a estrutura Lovaflex CH 130 oito dias após irradiação com raios gama, no intervalo de dose de radiação entre 0 - $30 \mathrm{kGy}$.

Na estrutura Lovaflex $\mathrm{CH} 130$ irradiada com feixe de elétrons (Fig.43) o deslocamento é maior na região de 240 - $300 \mathrm{~nm}$ para todo o intervalo de dose de radiação estudado. A partir da região de 300 nm, o seu comportamento é similar àquele do filme original (filme não irradiado). 
Na região de comprimento de onda de $250 \mathrm{~nm}$, onde a intensidade de absorção da estrutura Lovaflex $\mathrm{CH} 130$ irradiada atinge o seu máximo, a absorbância medida nas amostras irradiadas com feixe de elétrons é cerca de 18 a $27 \%$ maior que a absorbância das amostras irradiadas com raios gama.

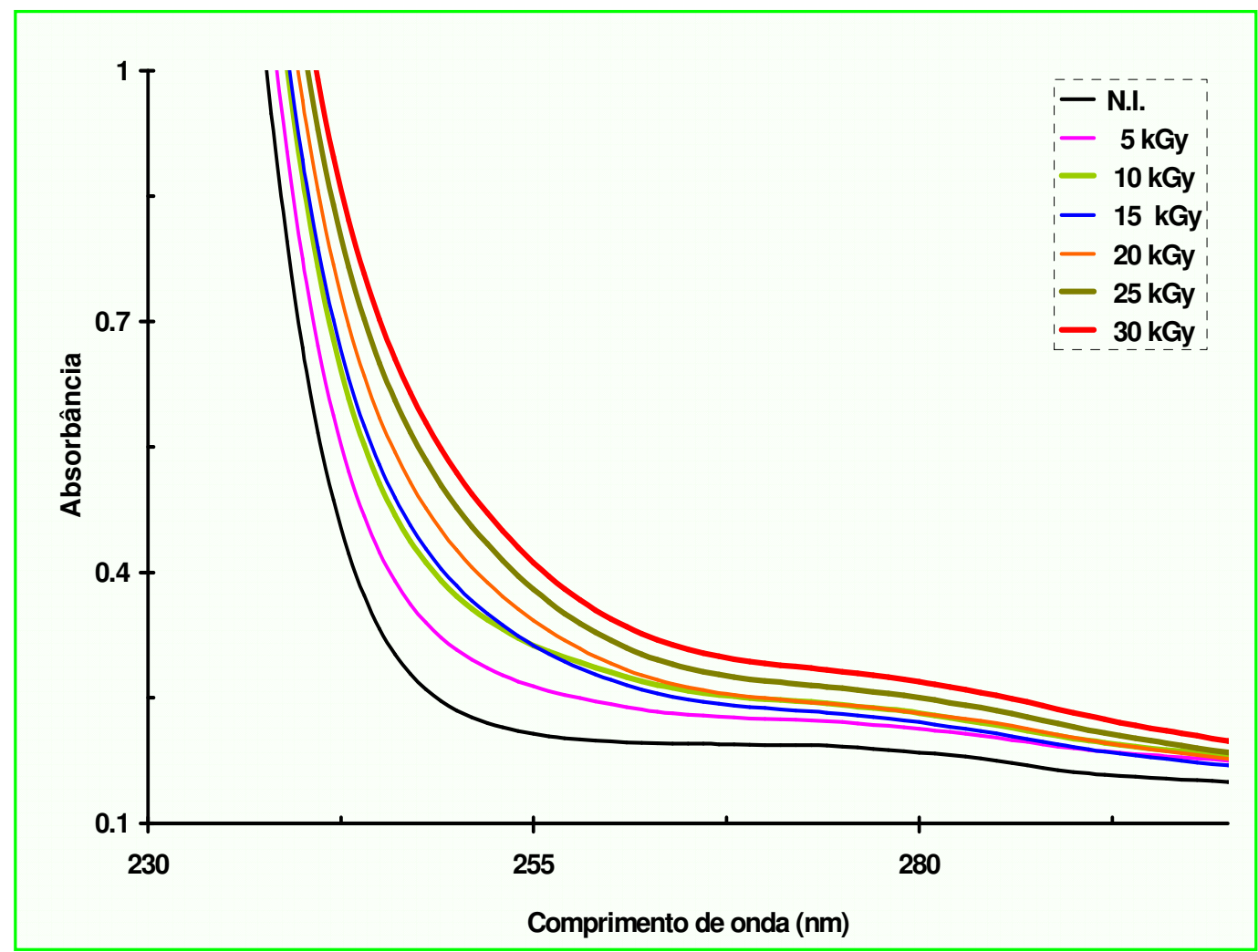

FIGURA 43 - Espectros de absorbância para a estrutura Lovaflex CH 130 oito dias após irradiação com feixe de elétrons, no intervalo de dose de radiação entre 0 - 30 kGy.

Nas FIG. 44 e 45 são mostradas a porcentagem de transmitância para o filme Unipac-PE-60 oito dias após a irradiação com raios gama (FIG.44) ou com feixe de elétrons (FIG.45). Observa-se nas FIG.44 e 45 redução na porcentagem de transimitância original do filme Unipac-PE-60, nas regiões de comprimento de onda menores que $250 \mathrm{~nm}$. Isto implica em ganho de barreira à luz para o Unipac-PE-60 nas regiões de comprimento de onda abaixo de $250 \mathrm{~nm}$. Os espectros mostrados nas FIG.44 e 45 indicam que o ganho de barreira à luz é 
maior na região de comprimento de onda de $220 \mathrm{~nm}$, sendo maior para o UnipacPE-60 irradiado com feixe de elétrons a partir da dose de $15 \mathrm{kGy}$.

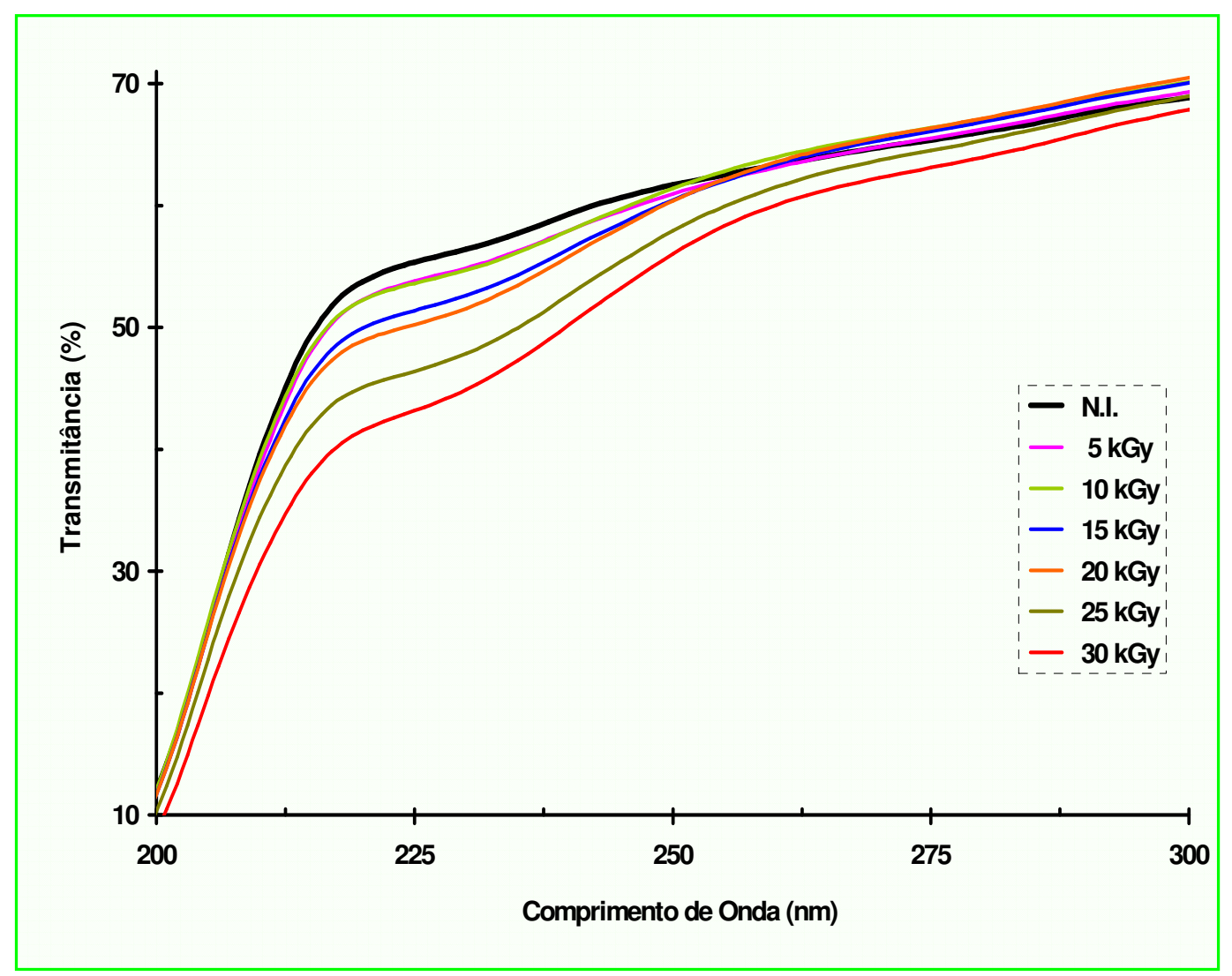

FIGURA 44 - Espectros de porcentagem de transmitância para o filme Unipac-PE60 oito dias após a irradiação com raios gama, no intervalo de dose de radiação entre 0 - 30 kGy. 


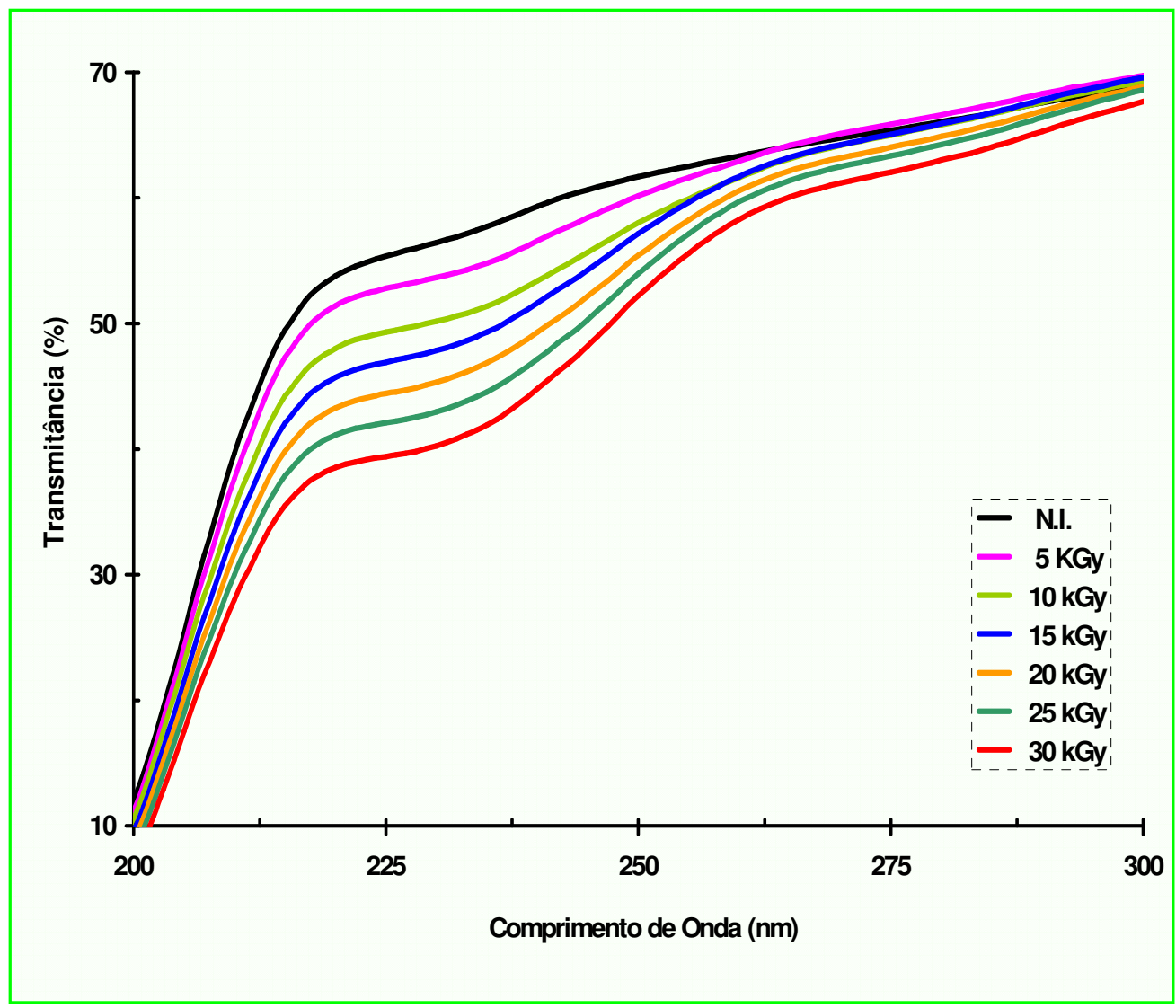

FIGURA 45 - Espectros de porcentagem de transmitância para o filme Unipac-PE60 oito dias após a irradiação com feixe de elétrons, no intervalo de dose de radiação entre 0 - 30 kGy.

Nas FIG.46 e 47 são mostradas a porcentagem de transmitância para a estrutura Lovaflex $\mathrm{CH} 130$ oito dias após a irradiação com raios gama (FIG.46) ou com feixe de elétrons (FIG.47).

Observa-se nas FIG.46 e 47 redução na porcentagem de transimitância nas regiões de comprimento de onda menores que $300 \mathrm{~nm}$ para a estrutura Lovaflex $\mathrm{CH} 130$ irradiada. Isto implica em ganho de barreira à luz para a estrutura nas regiões de comprimento de onda abaixo de $300 \mathrm{~nm}$. Acima de 300 $\mathrm{nm}$ verifica-se perda de barreira à luz para a estrutura Lovaflex $\mathrm{CH} 130$ irradiada com raios gama, principalmente no intervalo de dose de radiação entre 15 e 25 kGy. 


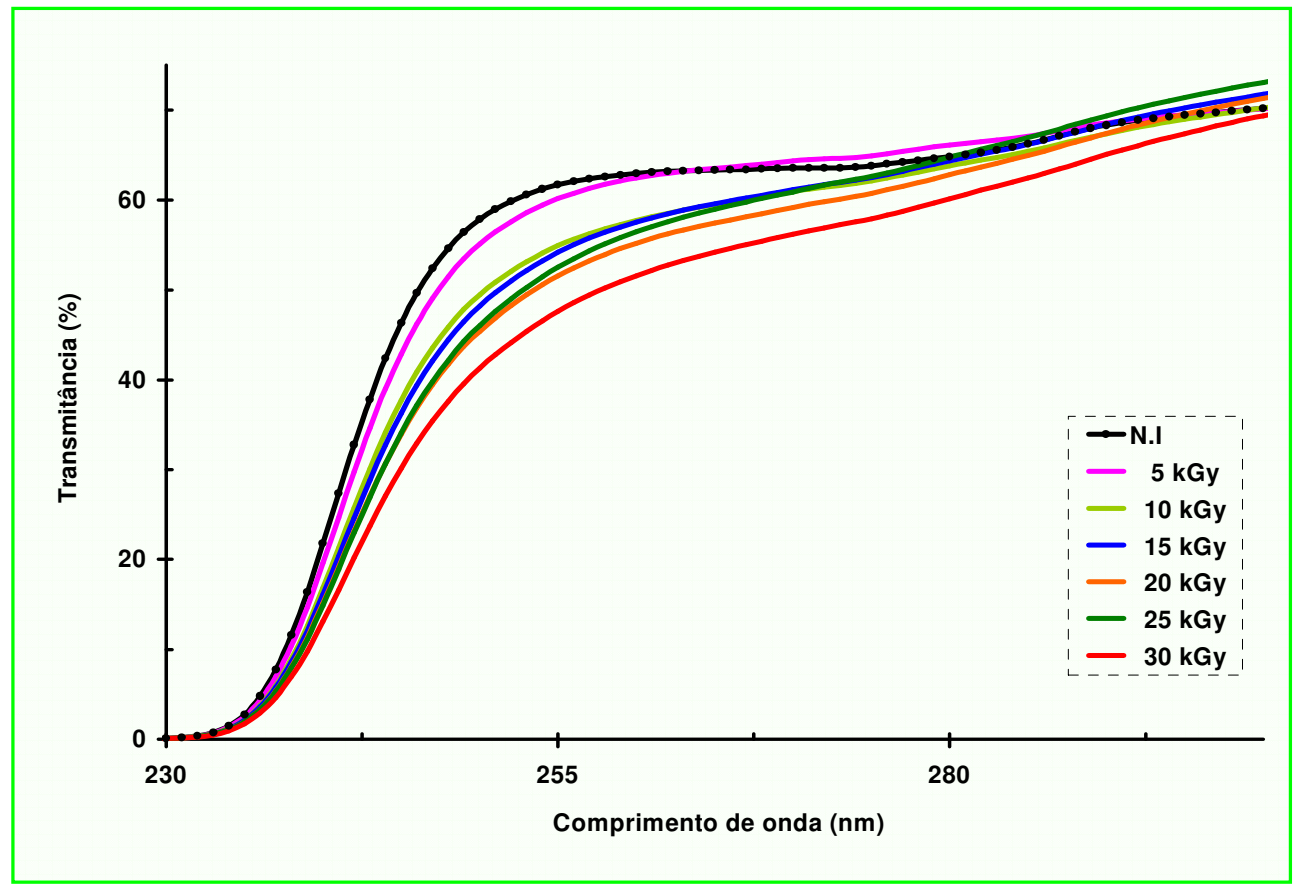

FIGURA 46 - Espectros de porcentagem de transmitância para a estrutura Lovaflex $\mathrm{CH} 130$ oito dias após a irradiação com raios gama, no intervalo de dose de radiação entre 0 - 30 kGy.

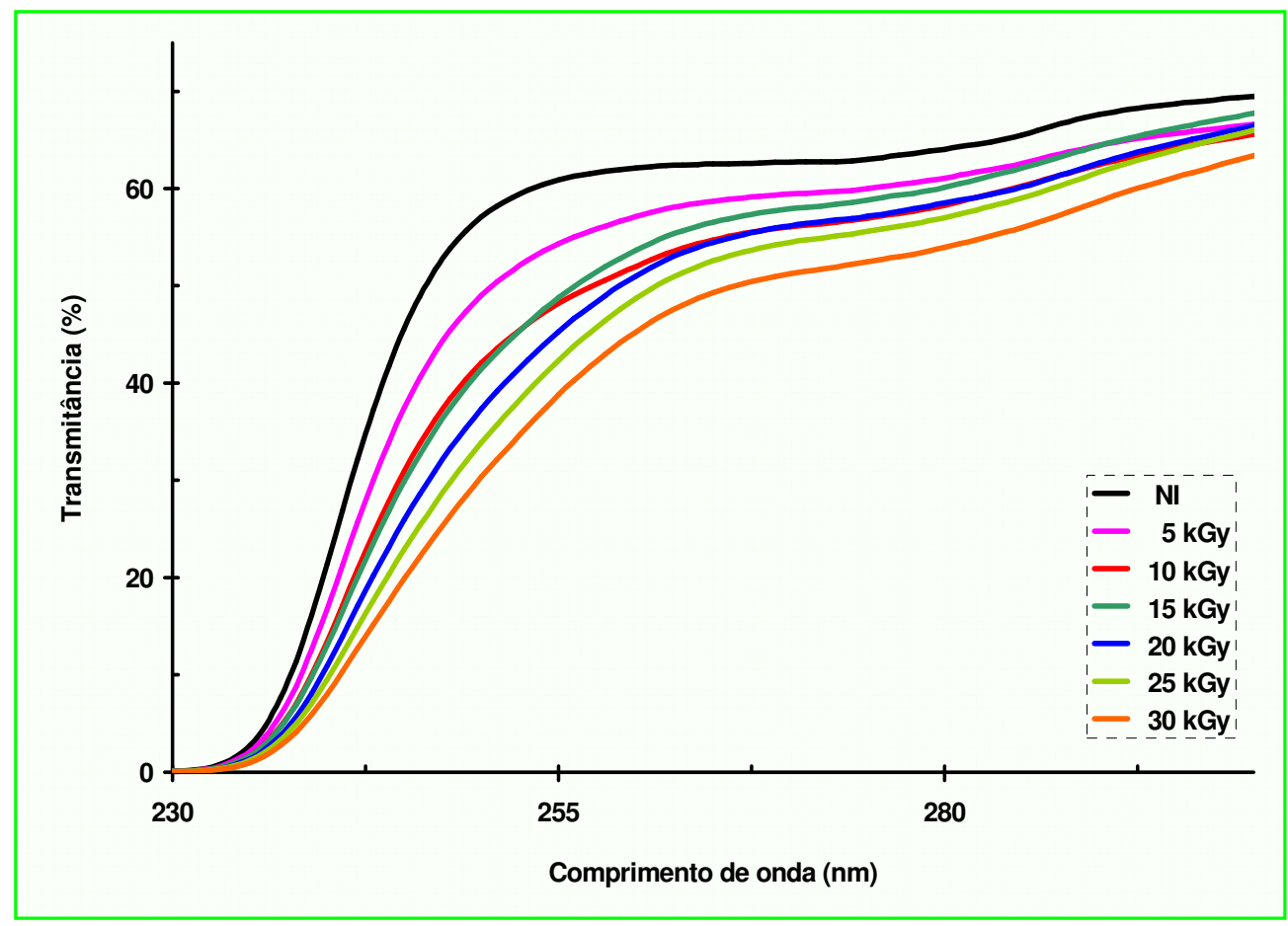

FIGURA 47 - Espectros de porcentagem de transmitância para a estrutura Lovaflex $\mathrm{CH} 130$ oito dias após a irradiação com feixe de elétrons, no intervalo de dose de radiação entre 0 - 30 kGy. 
O comportamento dos filmes Unipac-PE-60 e Lovaflex CH 130 irradiados com raios gama ou com feixe de elétrons, observado nas FIG. 40 a 47, indicam que a influência da radiação ionizante sobre as suas propriedades ópticas é maior nos baixos comprimentos de onda do espectro de energia, principalmente na região da radiação ultravioleta $(190-400 \mathrm{~nm})$. As mudanças nas propriedades ópticas originais desses filmes observadas após irradiação com raios gama ou com feixe de elétrons, podem ser devido a presença de insaturações e de compostos carbonílicos e hidroxílicos, formados durante o processo de irradiação na presença de oxigênio. A presença de carbonila $(C=0)$ no filme Unipac-PE-60, oito dias após a irradiação com raios gama, foi observada por espectroscopia no infravermelho com transformadas de Fourier $(\text { FTIR })^{[70]}$. Essa presença sugere a formação de produtos de oxidação no filme Unipac-PE-60, o qual é constituído exclusivamente de LDPE.

Considerando-se que a estrutura Lovaflex $\mathrm{CH} 130$ contém quatro camadas de LDPE e adesivos a base de LDPE, proveniente do mesmo fabricante, é de se esperar também a presença de $\mathrm{C}=\mathrm{O}$ e formação de produtos de oxidação no Lovaflex CH 130 após a irradiação.

Esses resultados indicam, a ocorrência da degradação oxidativa, durante a irradiação destes materiais de embalagens, com a formação de peróxidos e hidroperóxidos, que são produtos intermediários na formação de compostos hidroxílicos e carbonílicos.

Essas suposições vêm de encontro com a literatura onde é relatado que alguns produtos do processo de oxidação mostram absorção máxima em comprimentos de onda específicos, por exemplo, compostos primários de oxidação exibem valores máximos na região de comprimento de onde de 215-234 nm, e produtos de oxidação secundária nas regiões de $265 \mathrm{~nm}$ (TAB.3) ${ }^{[75]}$. 
TABELA 3 - Absorção máxima dos principais grupos cromóforos de produtos de oxidação

\begin{tabular}{l|c}
\hline \hline \multicolumn{1}{c|}{ Produto } & Máximo Comprimento de Onda na Região do Ultravioleta \\
& $(\mathrm{nm})$ \\
\hline Dieno & $215-230$ \\
Trieno & $265-370$ \\
Tetraeno & $310-320$ \\
Aldeídos e Cetonas & $265-280$ \\
$\alpha$-Dicetona & 280 \\
$\alpha$-Cetoaldeído & 282 \\
$\beta$-Dicetona & 274 \\
\hline \hline
\end{tabular}

O comportamento diferente do material irradiado com gama ou com feixe de elétrons, deve estar relacionado a taxa de dose. Considerando que as irradiações foram realizadas na presença de ar, na irradiação com raios gama, como a taxa de dose é muito baixa, quando comparada a irradiação com feixe de elétrons, possivelmente as reações de oxidação foram mais favorecidas nos filmes submetidos a radiação gama que a feixe de elétrons. Os resultados sugerem maior formação de compostos primários de oxidação, os quais exibem valores máximos de absorção na região de comprimento de onde de 215-234 nm, para o filme Unipac-PE-60 irradiado e de produtos de oxidação secundária para a estrutura Lovaflex CH 130 irradiada. Em contrapartida, as reações de degradação oxidativa formaram mais espécies radicalares, as quais continuaram reagindo com o oxigênio presente, com as cadeias poliméricas principais, com os monômeros residuais e com as moléculas menores formadas pelo processo de cisão e pela radiólise, até a sua recombinação por meio de uma reação de terminação.

Para as análises de UV/visível realizadas nos filmes dois meses após a irradiação, as mudanças ocorreram na mesma proporção da verificada nos filmes originais, em razão do envelhecimento natural dos materiais e, portanto, não devem ser atribuídas a irradiação.

As alterações observadas nos ensaios de UV/VIS destes materiais, assinalam para a predominância da degradação sobre a reticulação como 
consequência da irradiação. A degradação de polímeros por radiação é expressa como formação de radicais livres, produção de produtos da radiólise de massa molar baixa voláteis e não voláteis, produção de hidrogênio e subseqüente aumento de ligações insaturadas, cisão da cadeia polimérica e redução da massa molar $^{[17]}$.

O efeito da radiação sobre as propriedades ópticas dos filmes UnipacPE-60 e Lovaflex CH 130 observado neste trabalho é de grande interesse para a aplicação final destes filmes, uma vez que ocorre um ganho de barreira à luz, na região de comprimento de onda mais favorável à oxidação lipídica de alimentos gordurosos, região menor que $470 \mathrm{~nm}$. A luz é a principal causadora da deterioração oxidativa de alimento, encurtando a vida de prateleira do produto acondionado ${ }^{[75-77]}$. Além disso, as alterações observadas nos espectros de absorbância dos filmes irradiados, os quais sugerem um ligeiro amarelecimento, não são percebidas visualmente, duas semanas após a irradiação, portanto, são insuficientes para alterar a aparência final destes materiais o que reduziria a aceitação do consumidor.

\subsection{Permeabilidade ao Vapor D'Água.}

Nas FIG.48 e 49 são mostradas a taxa de permeabilidade ao vapor dágua em função da dose de radiação para o filme Unipac PE 60, irradiado com raios gama ou com feixe de elétrons, oito dias após a irradiação (FIG.48) e três meses após a irradiação (FIG.49).

Com relação ao filme Unipac-PE-60, os ensaios realizados oito dias após a irradiação (FIG.48) mostraram redução na taxa de permeabilidade ao vapor d'água do filme irradiado com raios gama ou com feixe de elétrons, quando comparado ao valor máximo e mínimo da taxa de permeabilidade do filme original, medida na mesma época, que está entre 7,2 e 8,2 g/ $\mathrm{m}^{2} / 24$ horas (área do gráfico indicada pelas linhas pontilhadas, FIG.48). 


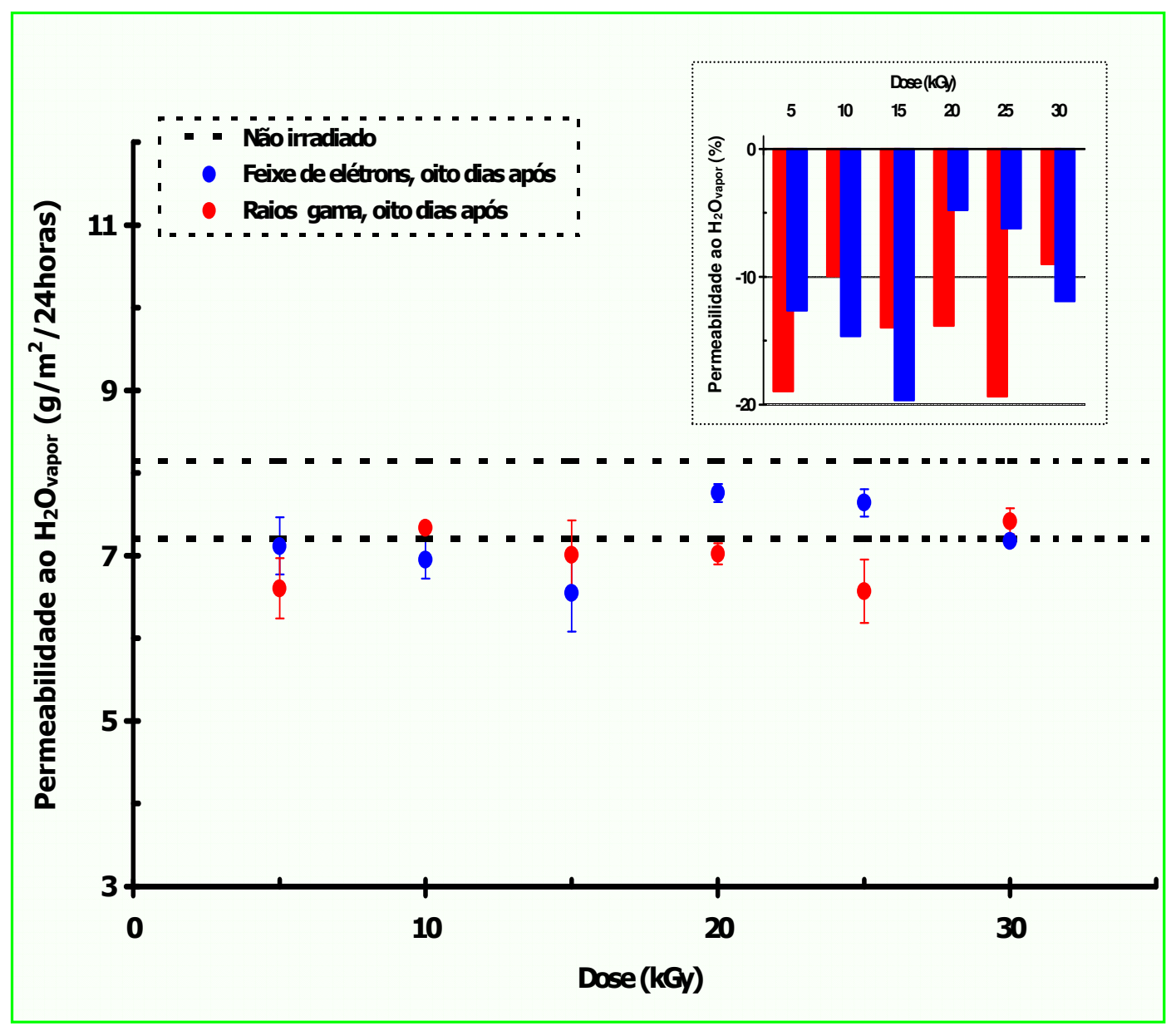

FIGURA 48 - Taxa de permeabilidade ao vapor dágua em função da dose de radiação para o Unipac-PE-60 oito dias após a irradiação com raios gama ou com feixe de elétrons.

Estes resultados indicam um sensível ganho de barreira ao vapor d'água para o filme Unipac-PE-60 oito dias após a irradiação com raios gama ou com feixe de elétrons, quando comparados a taxa de permeabilidade ao vapor d'água original (filme não irradiado). As variações percentuais na taxa de permeabilidade ao vapor d'água original do filme Unipac-PE-60 estão representadas no diagrama de barras, em detalhe no canto direito da FIG.48.

Com relação a taxa de permeabilidade ao vapor d'água do filme UnipacPE-60 três meses após a irradiação com raios gama ou com feixe de elétrons (FIG.49), pode-se observar uma sensível redução na sua taxa de permeabilidade 
ao vapor d'água, para as amostras irradiadas com feixe de elétrons nas doses de 10 e $30 \mathrm{kGy}$ (em cerca de 2 e 3\%, respectivamente), quando comparado ao valor da taxa de permeabilidade do filme original, medida na mesma época (área do gráfico indicada pela linha pontilhada em verde FIG.49).

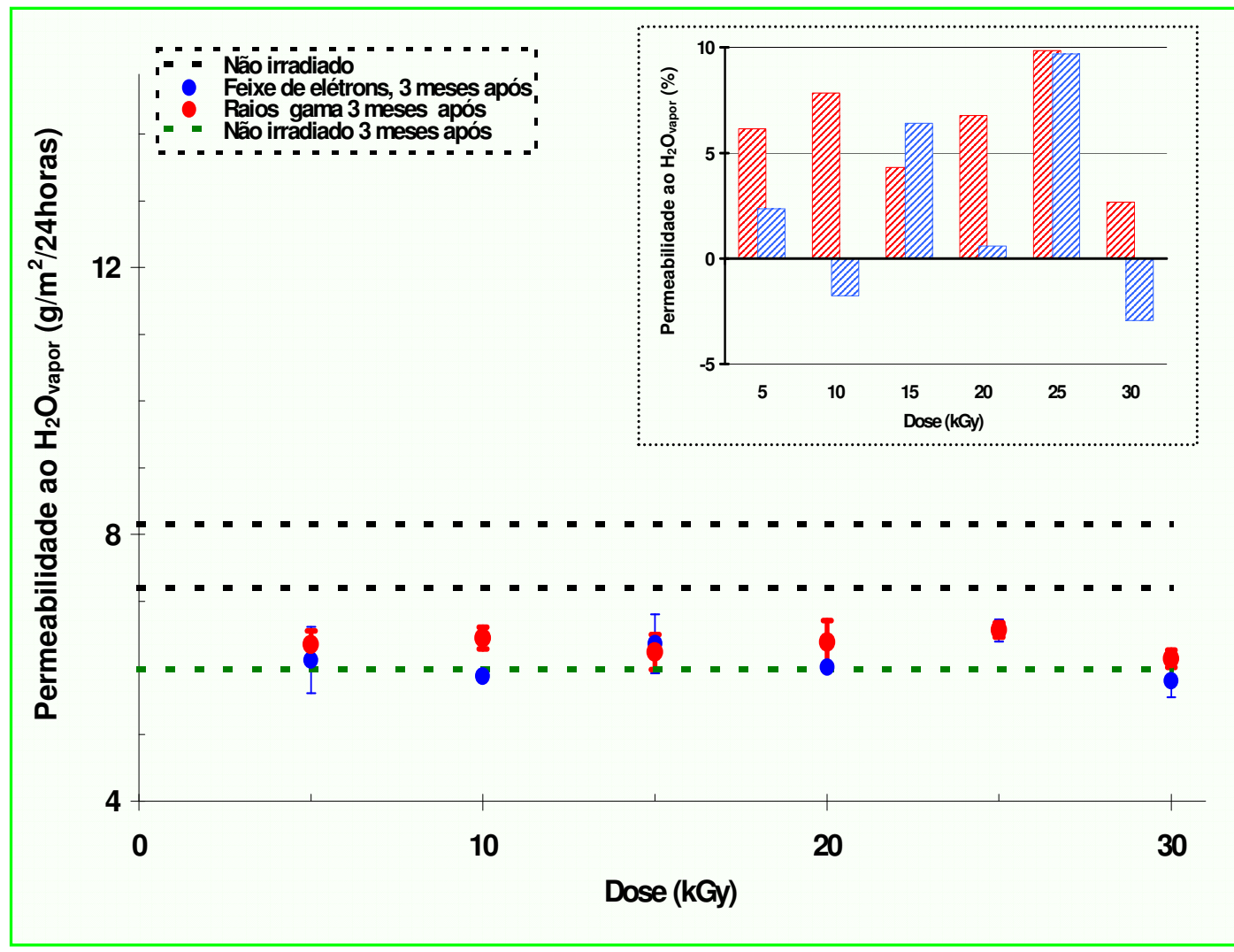

FIGURA 49 - Taxa de permeabilidade ao vapor dágua em função da dose de radiação para o Unipac-PE-60 três meses após a irradiação com raios gama ou com feixe de elétrons.

Os resultados apresentados na FIG. 49 indicam um sensível ganho de barreira ao vapor d'água para o filme Unipac-PE-60, três meses após a irradiação com feixe de elétrons nas doses de 10 e 30 kGy e perdas de barreira tanto para o filme irradiado com feixe de elétrons nas demais doses, como também para as irradiações com raios gama em todo o intervalo de dose estudado.

No diagrama de barras, em detalhe no canto direito da FIG. 49, estão representadas as variações percentuais da taxa de permeabilidade ao vapor 
d'água do Unipac-PE-60, três meses após a irradiação com raios gama ou com feixe de elétrons.

Na FIG.50 é apresentada uma comparação entre os valores da taxa de permeabilidade ao vapor d'água do Unipac-PE-60 não irradiado, oito dias e três meses após a irradiação e o seu valor limite de segurança (permeabilidade ao vapor d'água $<10 \mathrm{~g} / \mathrm{m}^{2} / 24 \mathrm{horas}$ ), estabelecido pelo fabricante para a sua comercialização.

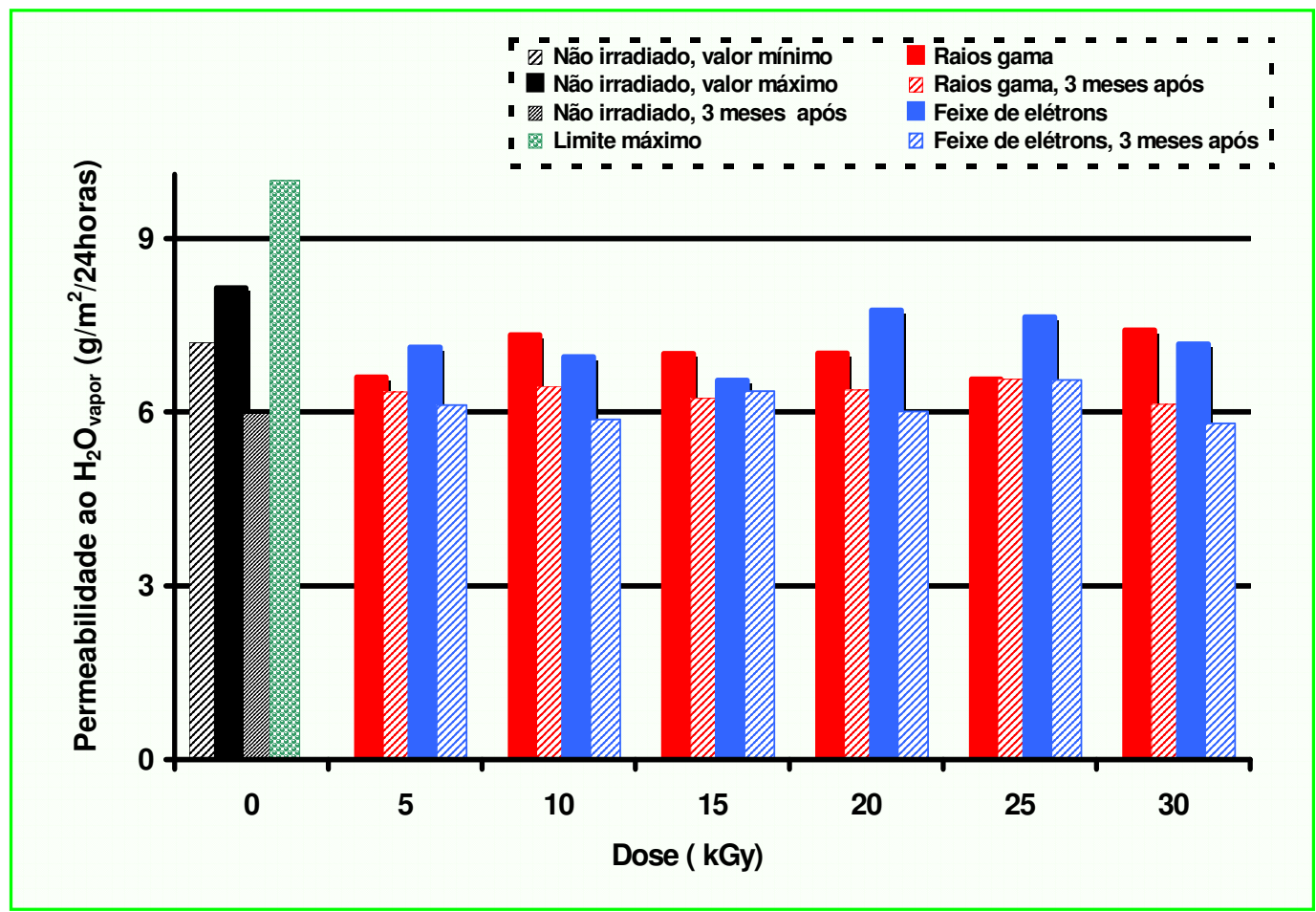

FIGURA 50 - Comparação entre os valores da taxa de permeabilidade ao vapor d'água do filme Unipac-PE-60 não irradiado, oito dias e três meses após a irradiação com raios gama ou com feixe de elétrons e o seu valor limite de segurança.

Pode-se observar na FIG.50 que embora o filme irradiado tenha apresentado, após três meses de irradiação, uma taxa de permeabilidade ao vapor d'água maior que o valor da sua taxa de permeabilidade original (filme não irradiado), medida na mesma época, esta ainda se encontra muito abaixo do valor do seu limite de segurança, estabelecido pelo fabricante para a sua 
comercialização não sendo, portanto, significativas para limitar ou inviabilizar as aplicações finais do do filme Unipac-PE-60.

Com relação ao Lovaflex $\mathrm{CH} 130$ (FIG. 51), a taxa de permeabilidade original do filme (não irradiado) está entre 3,9 e 4,3 g/ $/ \mathrm{m}^{2} / 24$ horas (área do gráfico indicada pelas linhas pontilhadas). Quando este material é irradiado com raios gama ou com feixe de elétrons pode-se observar, oito dias após a irradiação, uma tendência de aumento nas taxas de permeabilidade das amostras irradiadas com raios gama nas doses de 5, 10, 20 e 30 kGy e redução nas doses de 15 e 25 kGy.

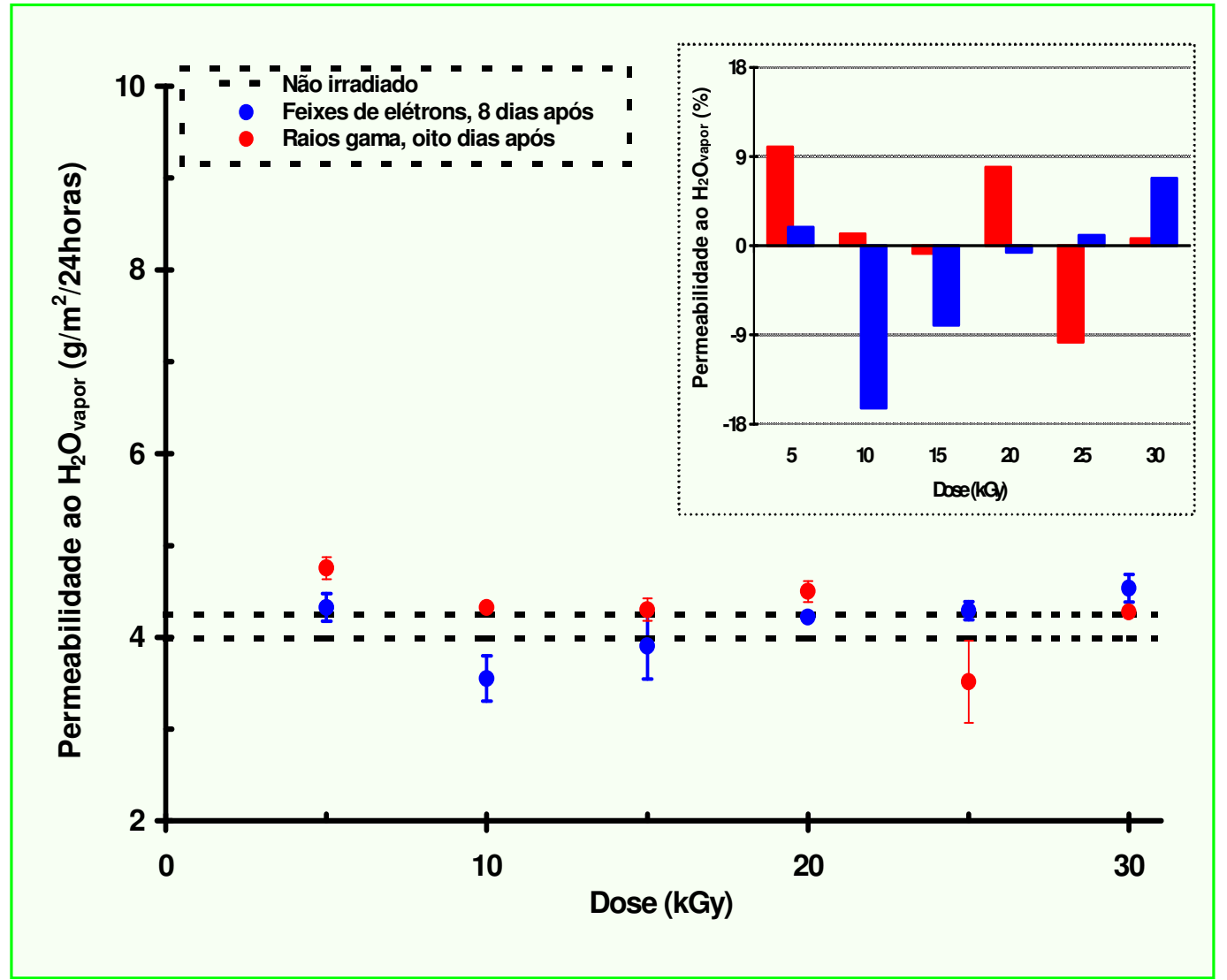

FIGURA 51 - Taxa de permeabilidade ao vapor dágua em função da dose de radiação para a estrutura Lovaflex $\mathrm{CH} 130$ oito dias após a irradiação com raios gama ou com feixe de elétrons. 
Observa-se também na FIG.51 um aumento nas taxas de permeabilidade das amostras irradiadas com feixe de elétrons nas doses de 5, 25, e 30 kGy e redução para as doses de radiação de 10 e 20 kGy.

Com relação a taxa de permeabilidade ao vapor d'água da estrutura Lovaflex $\mathrm{CH} 130$ três meses após a irradiação com raios gama ou com feixe de elétrons (FIG.52), pode-se observar uma sensível redução, da ordem de 2,5\% (dose de $30 \mathrm{kGy}$ ) a 9,5\% (dose de $20 \mathrm{kGy}$ ), na taxa de permeabilidade ao vapor d'água das amostras irradiadas com feixe de quando comparado ao valor da taxa de permeabilidade ao vapor d'água do filme original, medida na mesma época (área do gráfico indicada pela linha pontilhada em verde FIG.52).

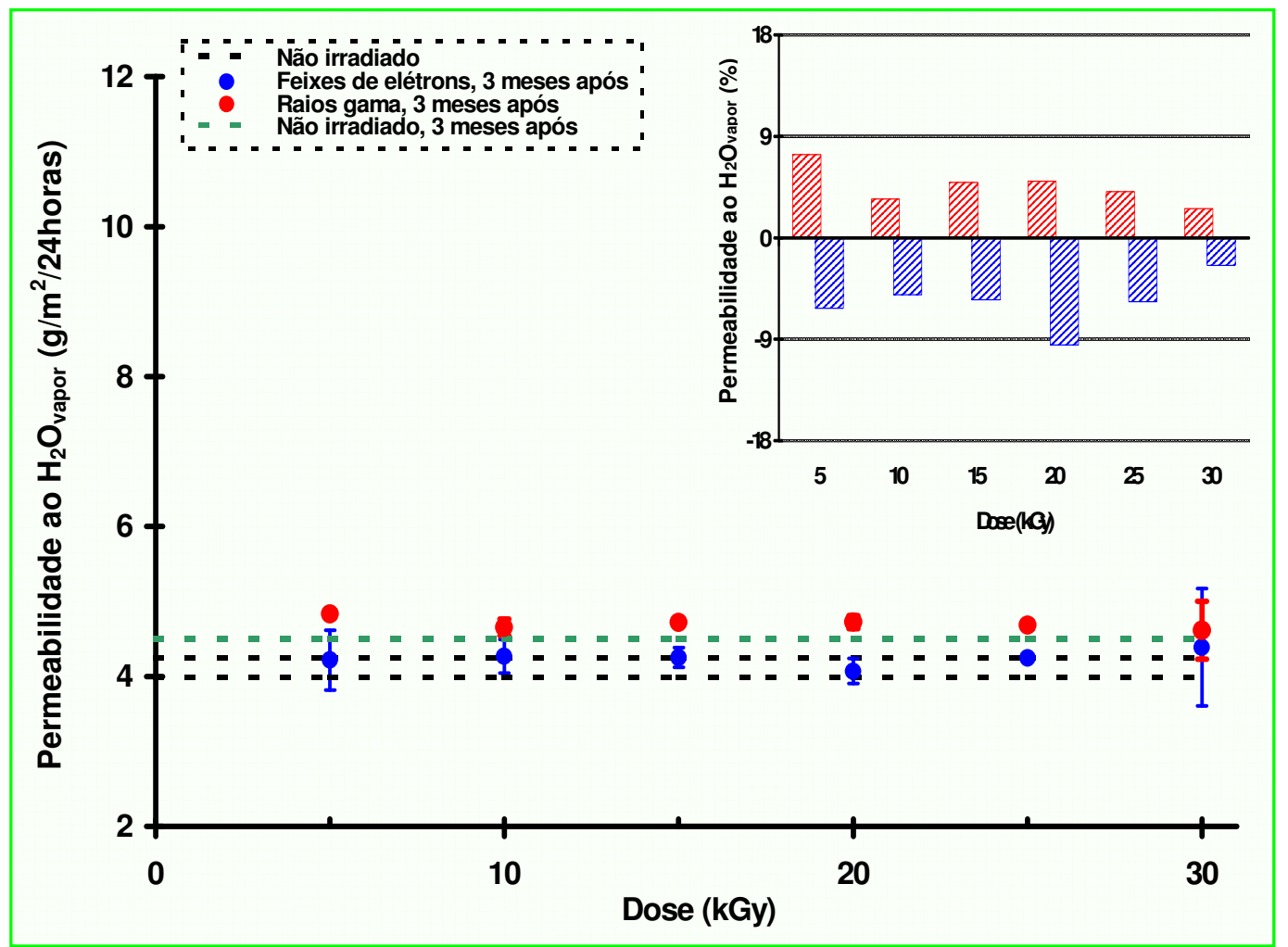

FIGURA 52 - Taxa de permeabilidade ao vapor dágua em função da dose de radiação para a estrutura Lovaflex $\mathrm{CH} 130$ três meses após a irradiação com raios gama ou com feixe de elétrons.

Observa-se também na FIG.52 que nas análises realizadas três meses após a irradiação com raios gama, ocorreu um aumento no valor da sua taxa de 
permealibidade ao vapor d'água original (filme não irradiado) medida na mesma época, para todo o intervalo de dose de radiação estudado. Os aumentos percentuais na taxa de permeabilidade ao vapor d'água para as amostras irradiadas com raios gama variaram entre $2,5 \%$ (dose de $30 \mathrm{kGy}$ ) e $7,5 \%$ (dose de 5 kGy).

Na FIG.53 é apresentada uma comparação entre os valores da taxa de permeabilidade ao vapor d'água da estrutura Lovaflex $\mathrm{CH} 130$ não irradiado, oito dias e três meses após a irradiação e o seu valor limite de segurança, estabelecido pelo fabricante para a sua comercialização (permeabilidade ao vapor dágua $<5$ $\mathrm{g} / \mathrm{m}^{2} / 24$ horas).

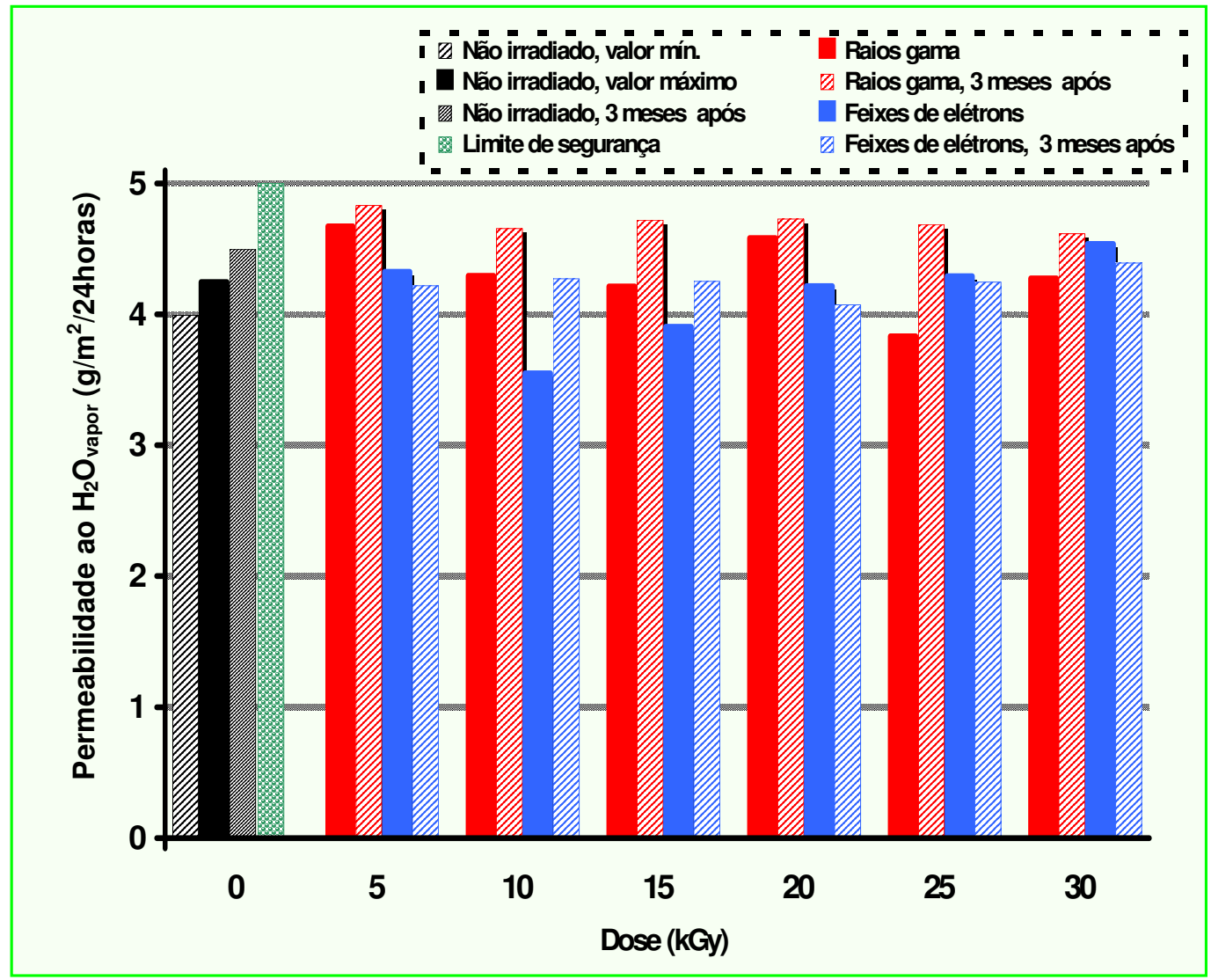

FIGURA 53 - Comparação entre os valores da taxa de permeabilidade ao vapor d'água da estrutura Lovaflex $\mathrm{CH} 130$ não irradiado, oito dias e três meses após a irradiação com raios gama ou com feixe de elétrons e o seu valor limite de segurança. 
Estes resultados indicam uma perda da barreira ao vapor d'água original da estrutura Lovaflex $\mathrm{CH} 130$ decorridos dois meses da irradiação com raios gama e ganho para as irradiações com feixe de elétrons. Contudo, as alterações na barreira ao vapor d'água do filme irradiado, quando comparado a sua barreira ao vapor d'água original (filme não irradiado), não são significativas para limitar ou inviabilizar as aplicações finais do material, uma vez que a sua barreira ao vapor d'água, após a irradiação, mantém-se muito abaixo do limite de segurança estabelecido pelo fabricante para a sua comercialização (permeabilidade ao vapor dágua $<5 \mathrm{~g} / \mathrm{m}^{2} / 24$ horas).

\subsection{Permeabilidade ao gás oxigênio}

Nas FIG.54 e 55 são mostrados o comportamento da permeabilidade ao gás oxigênio para a estrutura Lovaflex $\mathrm{CH}$ 130, irradiada com raios gama ou com feixe de elétrons, uma semana após a irradiação (Fig. 54) e três meses após a irradiação (Fig. 55), em relação aos valores da permeabilidade máxima e mínima do filme original.

Pode-se observar na FIG.54 que a taxa de permeabilidade ao oxigênio medida para a estrutura Lovaflex $\mathrm{CH} 130$ irradiada com raios gama e com feixe de elétrons encontram-se dentro da faixa de valores registrados para o filme não irradiado $\left(1,4\right.$ e $1,7 \mathrm{~cm}^{3} / \mathrm{m}^{2} / 24$ horas; área do gráfico indicada pelas linhas pontilhadas), exceto para as irradiações com feixe de elétrons na dose de 30 kGy. Nessa dose o valor da taxa de permeabilidade ao gás oxigênio medido para a estrutura Lovaflex $\mathrm{CH} 130$, apresentou uma redução da ordem de $34 \%$ em relação ao valor mínimo de taxa de permeabilidade ao oxigênio do filme original (não irradiado). Essa redução a 30 kGy, sugere que nessa dose de radiação o processo de cisão é mais intenso que nas demais doses estudadas neste trabalho. A cisão gera cadeias menores, o que facilita a organização da estrutura polimérica, causando aumento da fase cristalina, o que dificulta a difusão do oxigênio. 0 processo de reticulação aumenta a quantidade de ligações entre as cadeias e cria 
moléculas cada vez maiores e mais ramificadas, dificultando a organização da estrutura e aumentando a fase amorfa do material, o que pode facilitar a difusão do gás oxigênio através da estrutura.

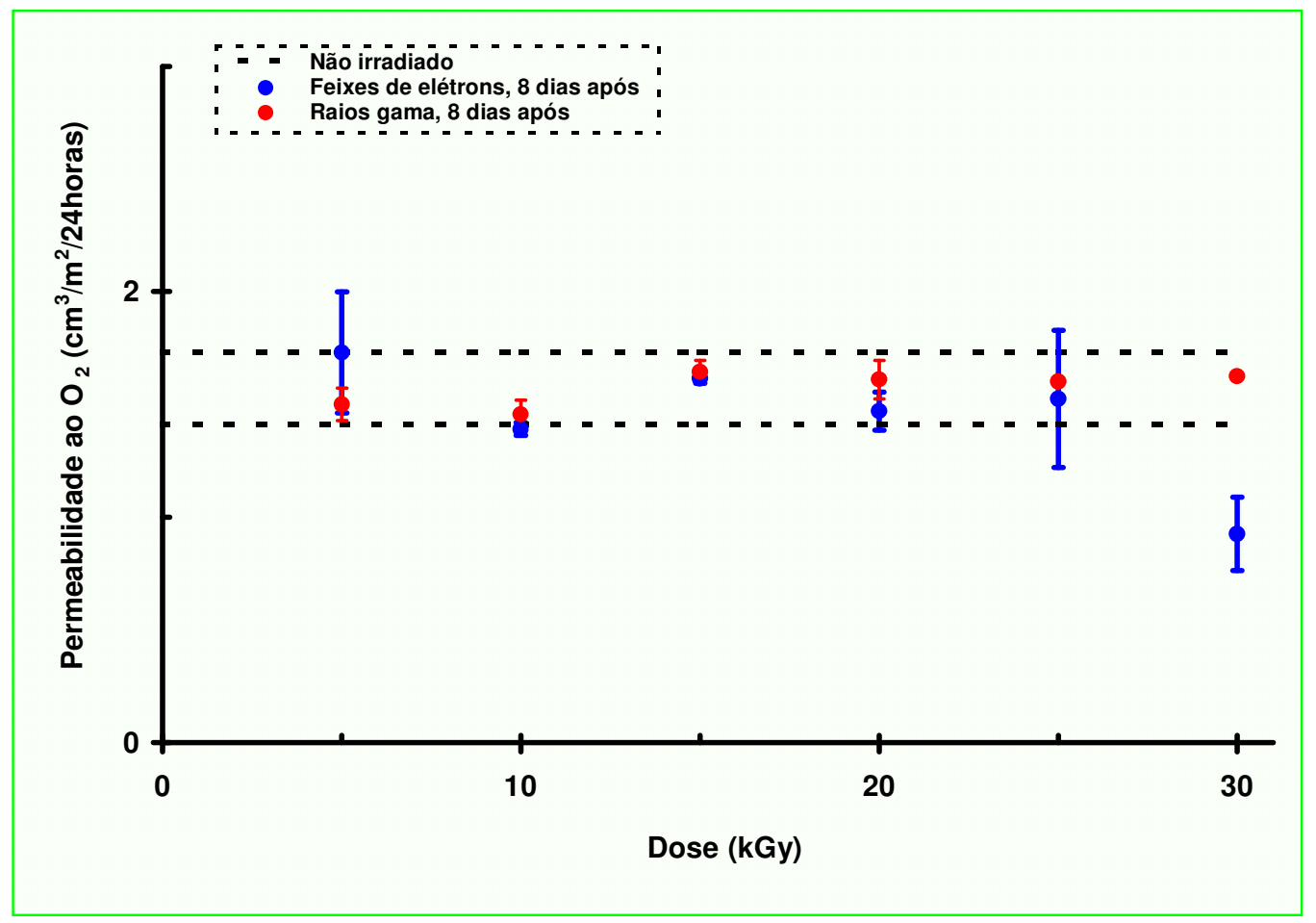

FIGURA 54 - Efeitos da dose de radiação na taxa de permeabilidade ao gás oxigênio para a estrutura Lovaflex $\mathrm{CH} 130$ oito dias após a irradiação com raios gama ou com feixe de elétrons.

Decorrido três meses da irradiação, pode-se observar que os valores da taxa de permeabilidade ao gás oxigênio medida no filme Lovaflex $\mathrm{CH} 130$ irradiado com raios gama ou com feixe de elétrons, se aproxima do valor da taxa de permeabilidade ao oxigênio do filme original medida na mesma época(FIG. 55). 


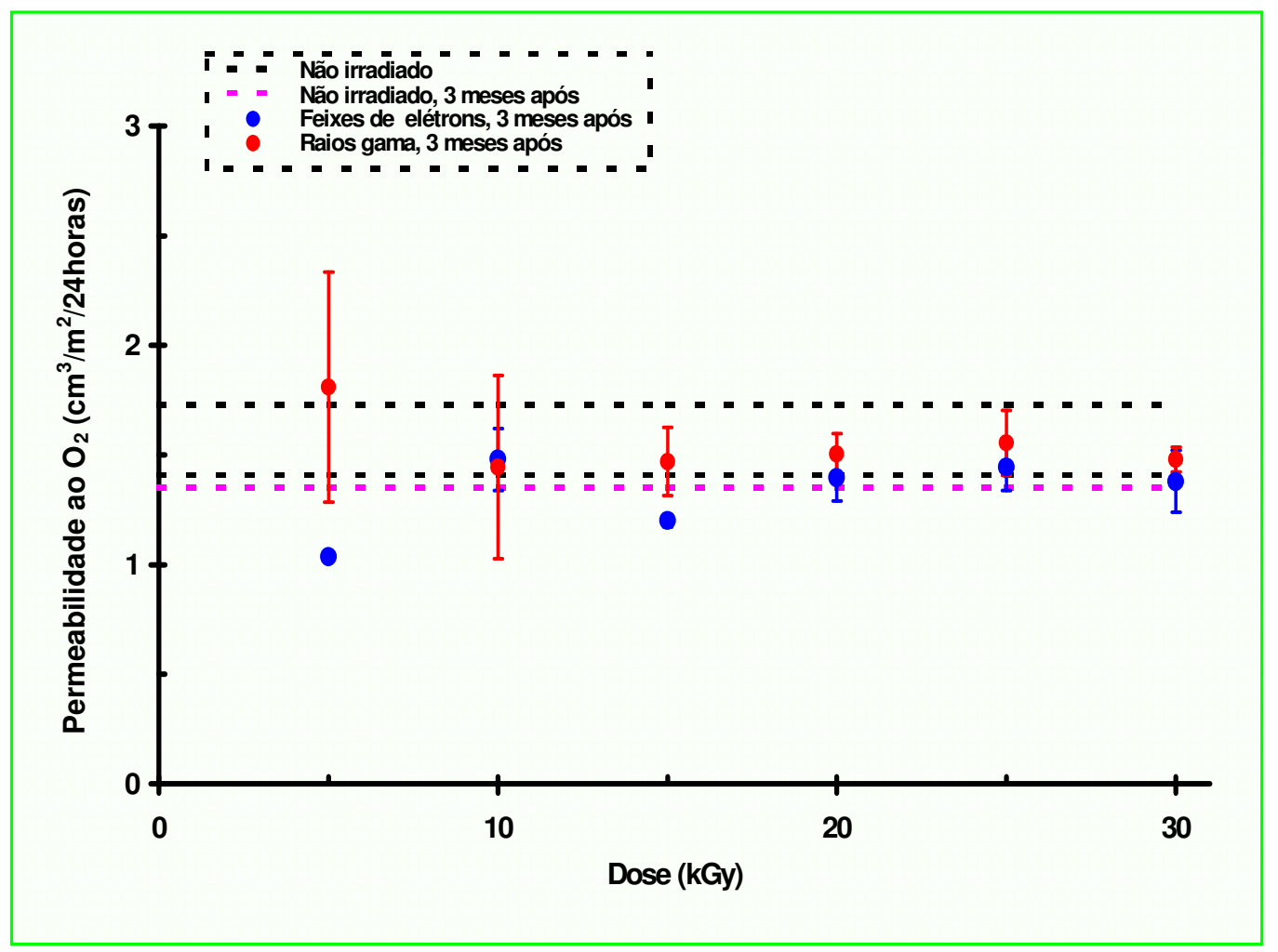

FIGURA 55 - Efeitos da dose de radiação na taxa de permeabilidade ao gás oxigênio para a estrutura Lovaflex $\mathrm{CH} 130$ três meses após a irradiação com raios gama ou com feixe de elétrons.

Os resultados mostrados na FIG.55 é um indício de que as moléculas menores, geradas no processo de cisão, tendem a buscar uma recombinação ao longo do tempo, se recombinando com as espécies radicalares presentes e revertendo o processo.

Na FIG.56 é apresentada uma comparação entre os valores da taxa de permeabilidade ao gás oxigênio da estrutura Lovaflex $\mathrm{CH} 130$ não irradiada, oito dias e três meses após a irradiação e o seu valor limite de segurança (permeabilidade ao gás oxigênio $<3 \mathrm{~cm}^{3} / \mathrm{m}^{2} / 24$ horas), estabelecido pelo fabricante para a sua comercialização. Desta maneira, mesmo que as alterações na barreira ao oxigênio da estrutura Lovaflex $\mathrm{CH}$ 130, observadas oito dias após a irradiação, se mantivessem ao longo do tempo, estas não limitariam a sua aplicação final, uma vez que, como é mostrado na FIG. 56 a faixa de valores 
medidos para a taxa de permeabilidade ao gás oxigênio oito dias após a irradiação encontra-se abaixo do seu valor limite de seguraça.

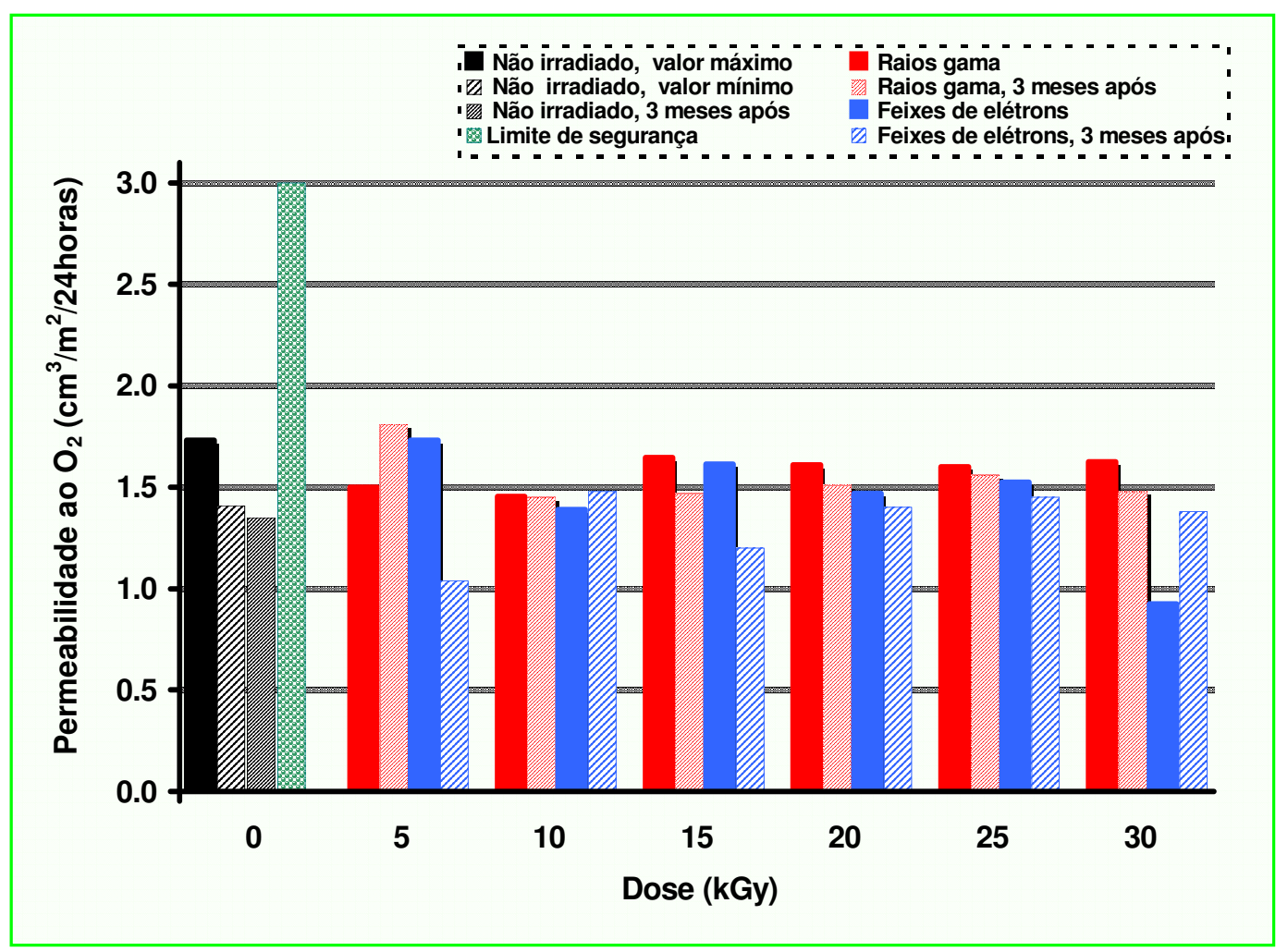

FIGURA 56 - Comparação entre os valores da taxa de permeabilidade ao gás oxigênio da estrutura Lovaflex $\mathrm{CH} 130$ não irradiada, oito dias e três meses após a irradiação com raios gama ou com feixe de elétrons e o seu valor limite de segurança.

\subsection{Ensaios de migração total em simulantes para alimentos}

\subsubsection{Migração total em n-heptano e em ácido acétio a 3\% para o filme Unipac-PE-60}

Nas FIG.57 e 58 são mostrados comparativos da variação dos valores médios dos resíduos de migração total em n-heptano (FIG.57) e ácido acético a 3\% (FIG.58) para o filme Unipac-PE-60 irradiado com raios gama ou com feixe de elétrons em relação aos valores dos resíduos do filme original e o limite máximo recomendado pela legislação em vigor ${ }^{[65]}$. 


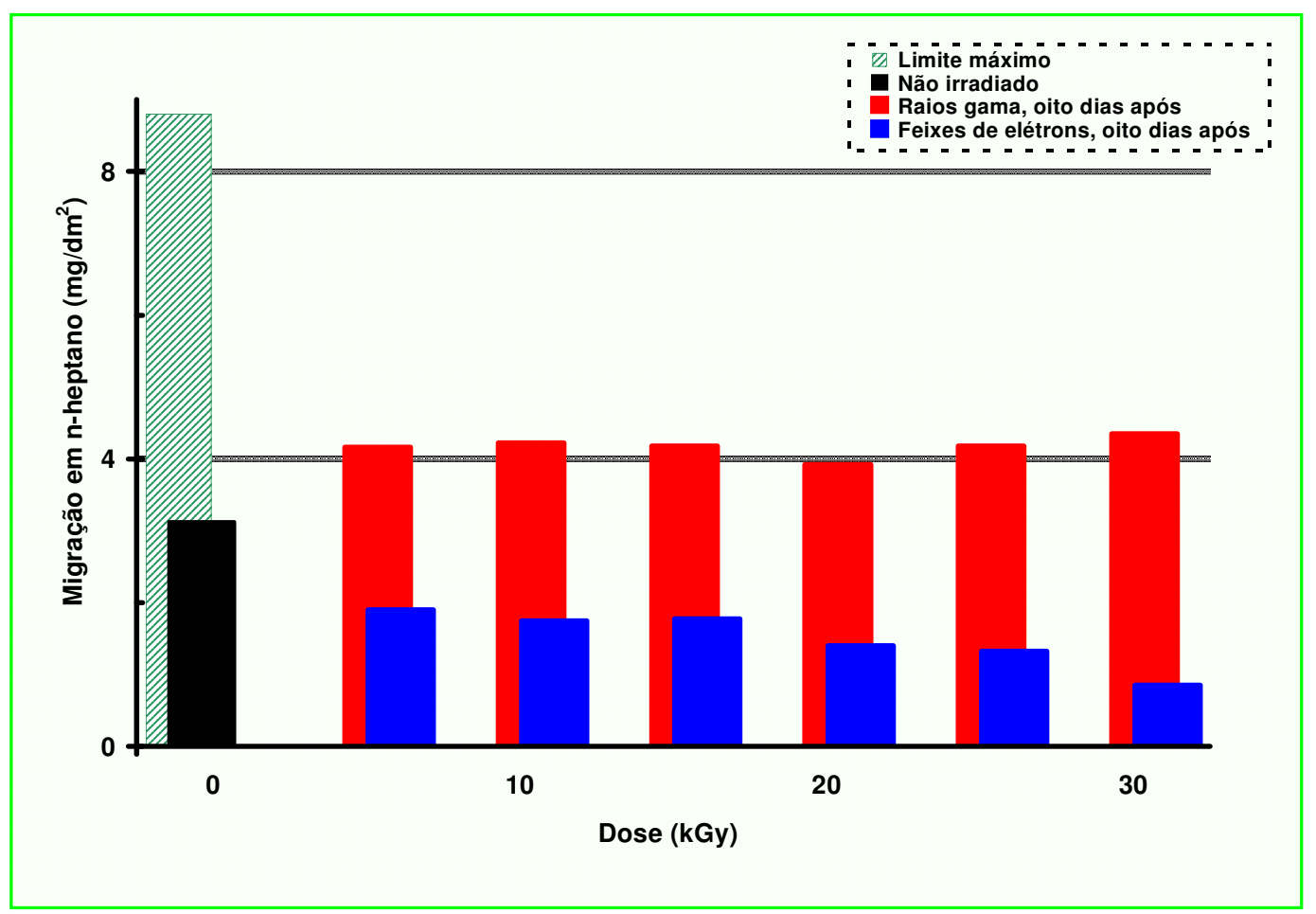

FIGURA 57 - Comparativo da variação dos valores médios dos resíduos de migração total em n-heptano para o filme Unipac-PE-60 irradiado com raios gama ou com feixe de elétrons

O limite máximo de migração total recomendado pela legislação em vigor ${ }^{[65]}$ é de $8,0 \mathrm{mg}$ de resíduo/ $\mathrm{dm}^{2}$ de material polimérico, com uma tolerância de $10 \%$, sendo, portanto, de $8,8 \mathrm{mg} / \mathrm{dm}^{2}$ o valor máximo tolerável. Conforme é mostrado na FIG.57, os valores médios dos resíduos de migração total no simulante $\mathrm{n}$-heptano encontrados nas amostras do Filme Unipac-PE-60 irradiado com feixe de elétrons apresentaram-se abaixo do valor médio encontrado para o filme original (não irradiado), o qual por sua vez, encontra-se abaixo do valor máximo tolerável.

Nas irradiações com raios gama pode-se observar um aumento nos valores dos resíduos de migração total em $\mathrm{n}$-heptano em relação ao valor médio encontrado para o filme original, mas abaixo do valor máximo tolerável (FIG.57). 
Pode-se observar também na FIG.57 que quanto maior a dose de radiação com feixe de elétrons menor o valor médio dos resíduos de migração total no simulante n-heptano, o que em termos percentuais representou uma redução da ordem de 40 a $72 \%$, quando comparada ao valor médio dos resíduos de migração total medido no filme original. Nota-se também na mesma figura que valores médios dos resíduos de migração total no simulante n-heptano para o filme Unipac-PE-60 irradiado com raios gama aumentaram com as doses de radiação, atingindo valores percentuais da ordem de 32 a $40 \%$, quando comparados ao valor médio dos resíduos de migração total medido no filme original.

Com relação aos resíduos de migração total no simulante ácido acético a 3\% (FIG.58), pode-se observar que valores médios dos resíduos de migração total encontrados nas amostras do filme Unipac-PE-60 irradiado com raios gama ou com feixe de elétrons aumentaram com as doses de radiação.

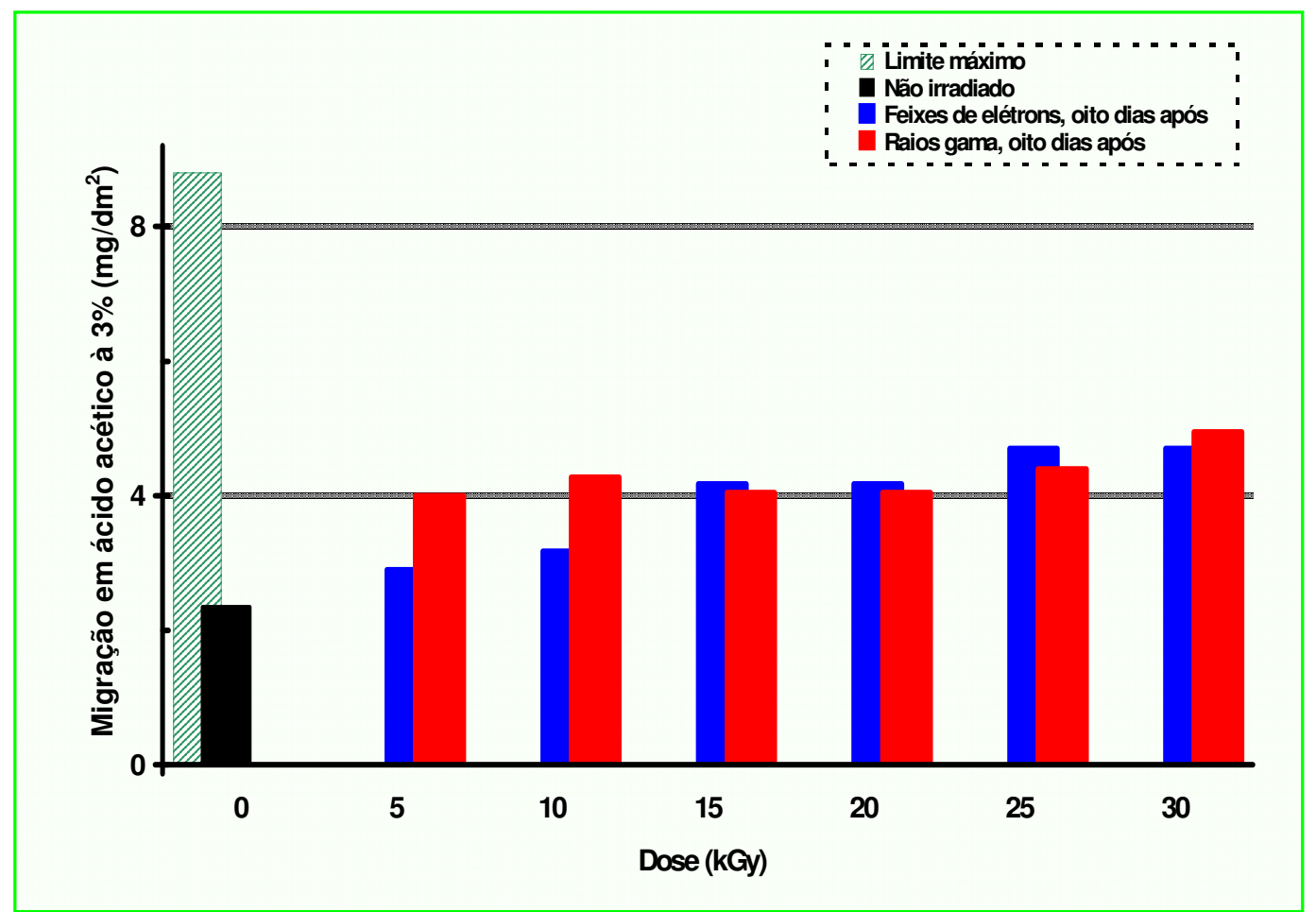

FIGURA 58 - Comparativo da variação dos valores médios dos resíduos de migração total em ácido acético a 3\% para o filme Unipac-PE-60 irradiado com raios gama ou com feixe de elétrons 
Os resultados mostrados nas FIG. 57 e 58 indicam aumento na produção de resíduos detectáveis, capazes de migrarem para o produto cárneo acondicionado, nas amostras irradiadas com raios gama para resíduos detectáveis em simulantes aquosos (ácido acético a 3\%) e gordurosos (n-heptano) e com feixe de elétrons para resíduos detectáveis em simulantes aquosos (ácido acético a $3 \%)$.

Com relação aos valores médios dos resíduos de migração total encontrados no simulante n-heptano (FIG.57), os reultados mostraram um aumento da ordem de 33 a $40 \%$ na quantidade de resíduos de migração total detectáveis para o filme Unipac-PE-60 irradiado com raios gama e uma redução da ordem de 40 a $73 \%$ para as irradiações com feixe de elétrons, quando comparada com a quantidade de resíduos de migração total detectáveis presentes no filme Unipac-PE-60 original (filme não irradiado).

O aumento nos valores médios dos resíduos de migração total no simulante ácido acético a 3\% (FIG.58) para o filme Unipac-PE-60 irradiado atingiu valores percentuais da ordem de 70 a $110 \%$ para as irradiações com raios gama e da ordem de 23 a $100 \%$ para as irradiações com feixe de elétrons, quando comparado ao valor médio dos resíduos de migração total detectáveis presentes nas amostras do filme Unipac-PE-60 original.

\subsubsection{Migração Total em n-heptano e em ácido acétio a $3 \%$ para a estrutura Lovaflex CH 130}

Nas FIG.59 e 60 são mostrados comparativos da variação dos valores médios dos resíduos de migração total em n-heptano (FIG.59) e ácido acético a 3\% (FIG.60) na estrutura Lovaflex $\mathrm{CH} 130$ irradiada com raios gama ou com feixe de elétrons, em relação ao valor médio dos resíduos de migração total encontrados na estrutura Lovaflex $\mathrm{CH} 130$ original e o valor máximo tolerável recomendado pela legislação em vigor ${ }^{[65]}$. 


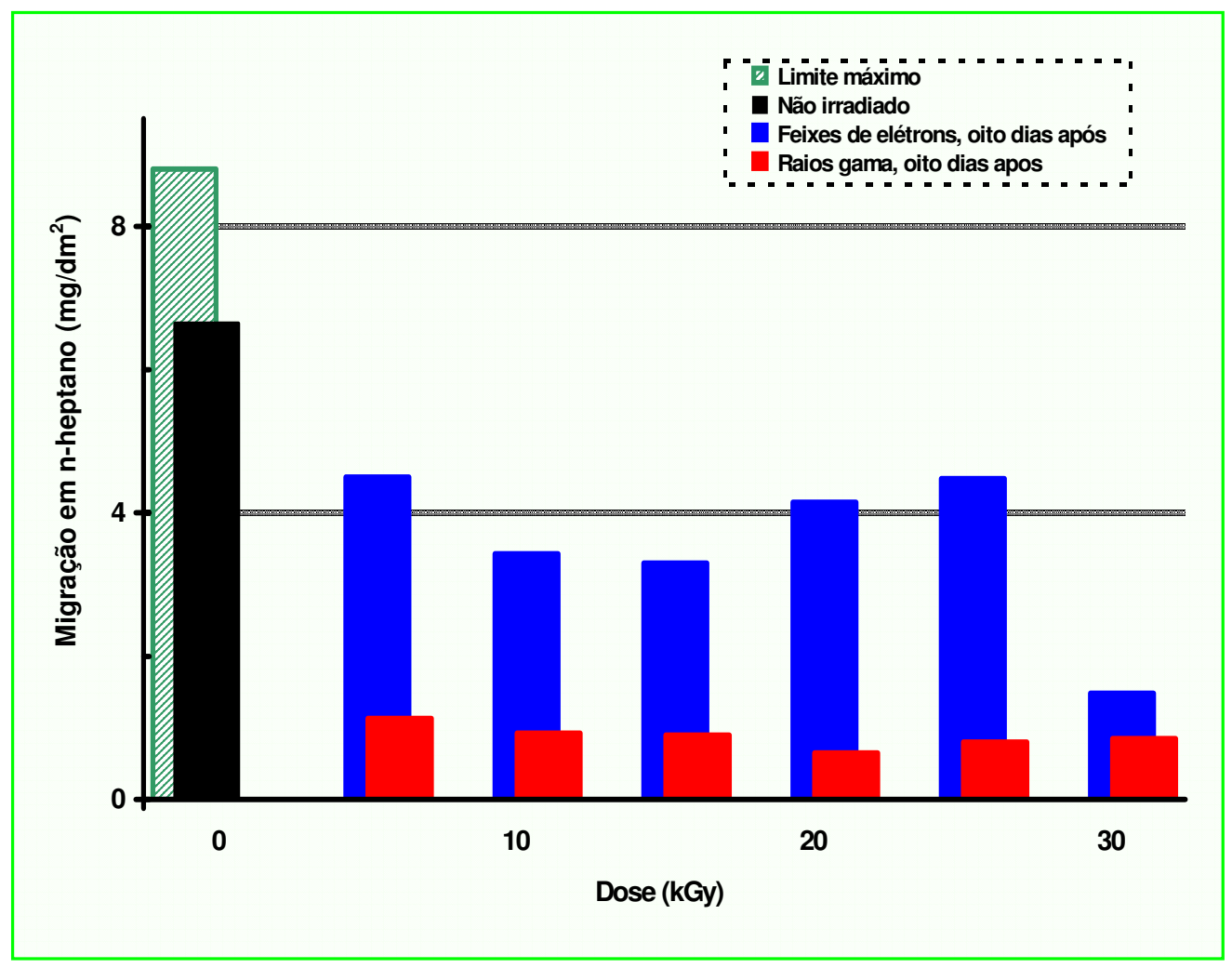

FIGURA 59 - Comparativo da variação dos valores médios dos resíduos de migração total em n-heptano para a estrutura Lovaflex $\mathrm{CH} 130$ irradiada com raios gama ou com feixe de elétrons

Conforme é mostrado na FIG.59, os valores de migração total encontrados nas amostras do Lovaflex $\mathrm{CH} 130$ irradiado com raios gama ou com feixe de elétrons para o simulante $\mathrm{n}$-heptano, apresentaram-se abaixo dos valores obtidos para a estrutura Lovaflex $\mathrm{CH} 130$ original (não irradiada), o qual por sua vez, apresenta-se também abaixo do valor máximo tolerável. Isto indica que a radiação ionizante, nas doses de radiação absorvida, utilizadas neste estudo, além de não produzir resíduos detectáveis em simulantes gordurosos (n-heptano), capazes de migrarem para o produto cárneo acondicionado, promoveu, por meio de reações de cisão e recombinação a redução dos monômeros e outras impurezas residuais presentes na estrutura Lovaflex $\mathrm{CH} 130$ original. 
Com relação aos resíduos de migração total no simulante ácido acético a 3\% (FIG.60), pode-se observar que os valores médios dos resíduos de migração total encontrado nas amostras da estrutura Lovaflex $\mathrm{CH} 130$ irradiada com raios gama aumentaram com a dose de radiação e nas amostras da estrutura irradiadas com feixe de elétrons apresentaram redução.

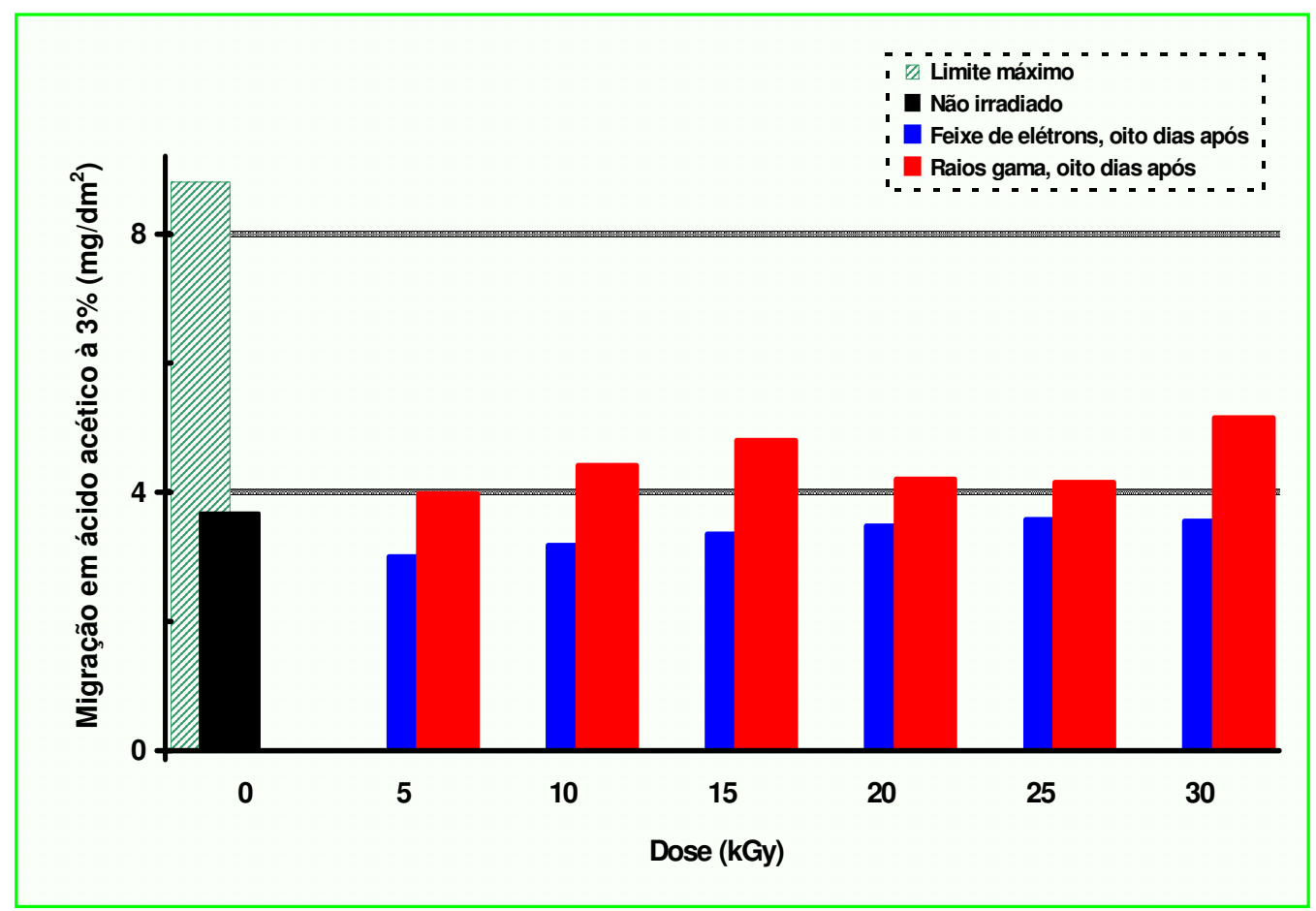

FIGURA 60 - Comparativo da variação dos valores médios dos resíduos de migração total em ácido acético a $3 \%$ para a estrutura Lovaflex $\mathrm{CH} 130$ irradiada com raios gama ou com feixe de elétrons

Os resultados mostrados nas FIG. 57 a 60 indicam que a radiação com raios gama tende a produzir mais resíduos detectáveis, capazes de migrarem para o produto cárneo acondicionado nos materiais de embalagens avaliados neste estudo (monocamada Unipac-PE-60 e multicamadas Lovaflex $\mathrm{CH}$ 130) que a radiação com feixe de elétrons, especialmente os resíduos de migração total passíveis de deteç̧ão em simulantes aquosos (ácido acético a 3\%). Isto se deve, provavelmente a menor taxa de dose da radiação gama $(3,48-4,43 \mathrm{kGy} / \mathrm{h})$ quando comparada a radiação com feixe de elétrons $(11,22 \mathrm{kGy} / \mathrm{s})$. Quanto menor a taxa de dose para as irradiações de polímeros realizadas na presença de ar, maior a 
interação dos radicais livres formados pela radiação com o oxigênio, maior a formação de peróxidos e hidroperóxidos e de macroradicais passíveis de reação com as macromoléculas dos polímeros e com os aditivos presentes. Consequentemente, maior a probabilidade de cisão de cadeia polimérica e formação de produtos de massa molar média baixa e de sub-produtos da degradação de aditivos, entre outros. Quanto maior a taxa de dose, maior a probabilidade de recombinação dos radicais formados por meio de reações de terminação, tendendo a obtenção de produtos de massa molar média maiores.

\subsection{Análises de produtos voláteis}

Embora tanto o filme Unipac-PE-60 como o Lovaflex $\mathrm{CH} 130$ irradiados com feixe de elétrons ou raios gama tenham apresentado, após a irradiação, odor característico de ranço, as análises de cromatografia gasosa não detectaram nenhum pico. Provavelmente a técnica utilizada não é sensível o suficiente para detectar tais alterações. Durante o processamento das resinas presentes nestes filmes, bem como no próprio processamento dos filmes, são adicionados aditivos deslizantes à base de amida, as oleamida ou as eurocamida. Estes aditivos, quando submetidos a radiação, sofrem preferencialmente degradação e liberam produtos voláteis, incluíndo ácidos carboxílicos, que apresentam odor característico de ranço. Outros aditivos também podem sofrer processos degradativos e gerar odores indesejáveis. Produtos de baixa massa molar gerados

pela radiólise da resina irradiada também causam alterações de odor [24, 40]. Portanto, acredita-se que os sub-produtos voláteis formados pela degradação de aditivos vários ou radiólise do material irradiado, tenham volatilizado durante a preparação das amostras, explicando o odor detectado nas amostras dos filmes irradiados, imediatamente após a irradiação. 


\section{CONCLUSÕES}

De acôrdo com os ensaios realizados pode-se concluir que:

As reações de cisão predominaram sobre as reações de reticulação tanto para o filme Unipac-PE-60 como para a estrutura Lovaflex CH 130, ambos irradiados com raios gama ou feixe de elétrons, no intervalo de dose entre 0 e $30 \mathrm{kGy}$, à temperatura ambiente, presença de ar.

> As variações observadas na resistência à tração e na deformação elástica do filme monocamada Unipac-PE-60 e da estrutura coextrusada Lovaflex $\mathrm{CH}$ 130, não limitam a aplicação final desses materiais uma vez que:

> Os filmes não apresentaram resistência mecânica inferior ao limite de segurança estabelecido pelo fabricante para a sua comercialização em nenhuma dose e período em que foram estudados.

> Nas doses de radiação de interesse para a irradiação de produtos cárneos (até $10 \mathrm{kGy}$ ), os valores médios da resistência à tração foram 55 a $83 \%$ maiores que o limite de segurança para o Unipac-PE-60 e 73 a 108\% maiores para o Lovaflex $\mathrm{CH} 130$.

> Na dose de interesse com vista a esterilização de embalagens (25 kGy), os valores médios de resistência à tração para o Unipac-PE-60 foram $10 \mathrm{a}$ $38 \%$ maiores que o limite de segurança e 60 a $100 \%$ maiores para o Lovaflex $\mathrm{CH} 130$.

> No intervalo de dose de radiação estudado a resistência à perfuração do filme Unipac-PE-60 e da estrutura Lovaflex $\mathrm{CH}$ 130, ambos irradiados com raios 
gama e feixe de elétrons, apresentaram ganhos para algumas doses de radiação e perdas para outras.

> Nas doses de radiação de interesse para a irradiação de produtos cárneos (até 10 kGy), a resistência à perfuração foi de 6 a 13\% maior que a original para o Unipac-PE-60 e de 4,5 a 7\% maior para o Lovaflex $\mathrm{CH} 130$ irradiado com raios gama. A resistência à perfuração do Lovaflex $\mathrm{CH} 130$ irradiado com feixe de elétrons nas doses de até $10 \mathrm{kGy}$ foi menor que a original em até $5 \%$.

Na dose de interesse com vista a esterilização de embalagens (25 kGy), a resistência à perfuração foi $19 \%$ maior que a original para o Unipac-PE-60 irradiado com feixe de elétrons e 7\% menor para as irradiações com raios gama. Na dose de 25 kGy a resistência à perfuração do Lovaflex $\mathrm{CH} 130$ foi $6 \%$ maior que a original para as irradiações com raios gama e menor para as irradiações com feixe de elétrons $(<1 \%)$.

As alterações na resistência à perfuração original do filme Unipac-PE-60 e da estrutura Lovaflex $\mathrm{CH} 130$ irradiados indicaram que a distância entre as cadeias das macromoléculas provavelmente aumentou em função de algumas doses de radiação estudadas e diminuiram para outras, em razão dos rearranjos ocorridos nas macromoléculas em decorrência dos processos de degradação e reticulação por radiação.

A influência da radiação ionizante sobre as propriedades ópticas do filme Unipac-PE-60 e da estrutura Lovaflex CH 130 é maior nos baixos comprimentos de onda do espectro de energia, principalmente na região da radiação ultravioleta (190-400nm).

As alterações nas propriedades ópticas originais dos filmes assinalam para a predominância da degradação sobre a reticulação, como consequência da irradiação, especialmente a ocorrência da degradação oxidativa, com a 
formação de peróxidos e hidroperóxidos, os quais são produtos intermediários na formação de compostos hidroxílicos e carbonílicos.

> $\mathrm{O}$ efeito da radiação sobre as propriedades ópticas do filme Unipac-PE-60 e da estrutura Lovaflex $\mathrm{CH} 130$ observado neste trabalho é de grande interesse para a aplicação final desses materiais, uma vez que ocorreu um ganho de barreira à luz, na região de comprimento de onda mais favorável à oxidação lipídica de alimentos gordurosos, região menor que $470 \mathrm{~nm}$.

$>$ O ligeiro amarelecimento e odor desagradável de ranço observados nos filmes estudados na primeira semana após a irradiação, não alteraram a aceitação do consumidor final pelos produtos acondicionados, uma vez que passadas duas semanas da irradiação retornaram à sua coloração e odor originais.

> Os filmes estudados não apresentaram permeabilidade ao vapor d'água acima do limite de segurança estabelecido pelo fabricante para a sua comercialização em nenhuma dose e período em que foi estudado.

> Nas doses de radiação de interesse para a irradiação de produtos cárneos (até 10 kGy), a permeabilidade ao vapor d'água foi 27 a $36 \%$ abaixo do limite de segurança para o Unipac-PE-60 irradiado e 7 a $29 \%$ abaixo para o Lovaflex $\mathrm{CH}$ 130 irradiado.

> Na dose de interesse com vista a esterilização de embalagens (25 kGy), a permeabilidade ao vapor d'água foi 24 a 34\% abaixo do limite de segurança para o Unipac-PE-60 e 6 a 23\% 6 a 23\% abaixo do limite de segurança para o Lovaflex $\mathrm{CH} 130$ irradiado.

> O Lovaflex CH 130 não apresentou permeabilidade ao gás oxigênio acima do limite de segurança estabelecido pelo fabricante para a sua comercialização em nenhuma dose e momento em que foi estudado. 
> Nas doses de radiação de interesse para a irradiação de produtos cárneos (até 10 kGy), a sua permeabilidade ao gás oxigênio foi 50 a 54\% abaixo do limite de segurança.

$>$ Na dose de interesse com vista a esterilização de embalagens (25 kGy), a sua permeabilidade ao gás oxigênio foi 47 a 52\% abaixo do limite limite de segurança.

$>$ Os filmes estudados não apresentaram resíduos de migração total nos simulantes n-heptano e ácido acético a 3\%, acima do valor do limite máximo tolerável em nenhuma dose e momento em que foram estudados.

Nas doses de radiação de interesse para a irradiação de produtos cárneos (até 10 kGy), a pocentagem dos resíduos de migração total em n-heptano foi 52 a $80 \%$ menor que o valor máximo tolerável para o filme Unipac-PE-60 irradiado e 61 a $89 \%$ menor para o Lovaflex $\mathrm{CH} 130$ irradiado. A pocentagem dos resíduos de migração total em ácido acétido a 3\% foi 51 a 54\% menor que o valor máximo tolerável para o filme Unipac-PE-60 irradiado e 50 a $64 \%$ menor para o Lovaflex $\mathrm{CH} 130$ irradiado.

> Na dose de interesse com vista a esterilização de embalagens (25 kGy), a pocentagem dos resíduos de migração total em n-heptano foi 53 a $85 \%$ menor que o valor máximo tolerável para o filme Unipac-PE-60 irradiado e 50 a 91\% menor para o Lovaflex $\mathrm{CH} 130$ irradiado. A pocentagem dos resíduos de migração total em ácido acétido a 3\% foi 47 a $50 \%$ menor que o valor máximo tolerável para o filme Unipac-PE-60 irradiado e 53 a $60 \%$ menor para o Lovaflex $\mathrm{CH} 130$ irradiado.

As análises de produtos voláteis realizadas por cromatografia gasosa não detectaram a presença de produtos voláteis nos filmes estudados, ambos irradiados com raios gama e feixe de elétrons. 
> O comportamento diferente do filme Unipac-PE-60 e da estrutura Lovaflex $\mathrm{CH}$ 130 frente a radiação com raios gama ou com feixe de elétrons, observado neste trabalho, deve estar relacionado a taxa de dose. Nas irradiações dos filmes com raios gama, onde a taxa de dose é muito baixa $(3,48-4,43 \mathrm{kGy} / \mathrm{h})$ em relação a taxa de dose com feixe de elétrons $(11,22 \mathrm{kGy} / \mathrm{s})$ as reações de oxidação foram, provavelmente, mais favorecidas.

> Tanto o filme monocamada Unipac-PE-60 como a estrutura multicamadas Lovaflex $\mathrm{CH} 130$ podem ser utilizados, sob o ponto de vista das propriedades avaliadas, como embalagens para produtos pasteurizáveis por radiação ou radioesterilizáveis tanto em irradiadores gama como em aceleradores de elétrons, nas doses estudadas, à temperatura ambiente e presença de ar. 


\section{SUGESTÕES PARA TRABALHOS FUTUROS}

\subsection{Avaliação das propriedades dos filmes estudados}

Para uma utilização e comercialização seguras dos filmes Unipac-PE-60 e Lovaflex $\mathrm{CH} 130$ irradiados sugere-se como trabalhos futuros:

\subsubsection{Ensaios mecânicos}

\section{> Ensaios mecânicos de tração no sentido "DT" (direção transversal)}

Realizar ensaios mecânicos de tração no sentido "DT" (direção transversal) para os filmes Unipac-PE-60 e Lovaflex CH 130 irradiados com raios gama e com feixe de elétrons. Justifíca-se esses ensaios, uma vez que as propriedades de tração estão associadas as questões críticas de produtividade, custo, perdas e segurança, com efeito desde o início da cadeia produtiva da indústria de produtos cárneos, ou seja, o fabricante dos filmes flexíveis, passando pelos frigoríficos, pela rede de distribuição e comercialização até chegar ao consumidor final.

\section{> Resistência à delaminação}

Realizar ensaios de resistência à delaminação na estrutura coextrusada Lovaflex $\mathrm{CH} 130$ irradiada com raios gama e feixe de elétrons. A resistência à delaminação é uma medida que indica a facilidade de separação de componentes de uma estrutura multicamadas. Os problemas de delaminação têm efeito negativo sobre a aparência do material, podendo também comprometer a integridade, as propriedades de barreira e a resistência mecânica de embalagens flexíveis ${ }^{[21]}$. Assim, é importante avaliar o grau de adesão entre as camadas da 
estrutura submetida a radiação com raios gama e feixe de elétrons em relação a estrutura original (não irradiada).

\subsubsection{Análises de migração total}

Realizar análises de migração total dos filmes Unipac-PE-60 e Lovaflex $\mathrm{CH}$ 130, ambos irradiados com raios gama e feixe de elétrons, no simulante aquoso água destilada e nos simulantes gordurosos azeite de oliva e iso-octano.

\subsubsection{Análise de produtos voláteis}

Desenvolver uma metodologia adequada para identificar e quantificar os produtos voláteis formados nos materiais de embalagens flexíveis irradiados, com o auxílio de técnicas de análises, como a CG/MS (cromatografia gasosa acoplada ao espectrômetro de massa), entre outras.

\subsubsection{Massa molar média viscosimétrica e densidade de ligações cruzadas}

Calcular a massa molar média viscosimétrica e a densidade de ligações cruzadas dos materiais poliméricos de embalagens flexíveis estudados, de modo a avaliar a ocorrência de cisão das cadeias poliméricas em função da dose de radiação e o seu efeito sobre a massa molar média desses materiais, bem como a influência do período denominado de "pós-radiação" no tamanho das cadeias poliméricas. Esses resultados contribuirão para um melhor conhecimento da extensão do efeito da radiação ionizante sobre os filmes estudados, uma vez que as propriedades físico-químicas dos polímeros são afetadas por mudanças na sua massa molar média ${ }^{[22]}$. 


\subsubsection{Avaliar a evolução das propriedades estudadas ao longo do tempo}

Estudar as propriedades mecânicas, ópticas, de barreira ao vapor d'água e ao gás oxigênio, bem como a porcentagem dos resíduos de migração total em simulantes de alimentos aquosos e gordurosos, decorridos 12 , 18 e 24 meses da data da irradiação a fim de que se possa avaliar o comportamento desses materiais frente a radiação ao longo do tempo. Salienta-se que a vida útil dos filmes originais é de 24 meses, especificada pelo fabricante.

\subsection{Avaliar a influência da temperatura de irradiação no desempenho dos filmes estudados}

Avaliar a influência da temperatura de irradiação nas propriedades dos filmes Unipac-PE-60 e Lovaflex $\mathrm{CH}$ 130, submetidos a tratamento por radiação ionizante nas condições estabelecida neste trabalho, mas variando-se a temperatura de irradiação para $-7^{\circ} \mathrm{C}$ e $-18^{\circ} \mathrm{C}$, com vistas à aplicação na pasteurização de produtos cárneos resfriados $\left(-7^{\circ} \mathrm{C}\right)$ e produtos cárneos congelados $\left(-18^{\circ} \mathrm{C}\right)$.

\subsection{Avaliar o desempenho das propriedades da estrutura coextrusada Lovaflex LM 110 após tratamento por radiação ionizante}

Avaliar o desempenho da estrutura coextrusada Lovaflex LM 110 irradiada com raios gama e feixe de elétrons, nas condições estabelecidas neste trabalho. A estrutura Lovaflex LM 110 é utilizada como filme de tampa para a estrutura Lovaflex $\mathrm{CH}$ 130, no sistema conhecido pelo seu nome em inglês "thermoform/fill/seal" (TFFS), que significa termoformagem/envase/selagem, um sistema muito usado no Brasil no segmento de produtos cárneos processados como a salsicha, a linguiça e os fatiados. 


\section{REFERÊNCIAS BIBLIOGRÁFICAS}

1 ROBERTSON, G. L. Food Packaging - Principles and Practice, New York, Marcel Dekker, Inc.,1993.

2 MOURA, R.A.; BANZATO, J.M. Embalagem, Unitilização \& Conteinerização Manual de Logística. v.3, 4a edição. São Paulo, 2003

3 MESTRINER, F. Novos hábitos exigem novas embalagens. Disponível em: < http://www.portaldapropaganda.com/design/abre >. Acesso em 15 out. 2005.

4 ABRE - ASSOCIAÇÃO BRASILEIRA DE EMBALAGEM; Apresenta um histórico sobre embalagem. Disponível em: < http://www.abre.org.br/apres setor embalagem.php >. Acesso em 15 out. 2005.

5 MADI, L. A Embalagem no Século XXI - Perspectivas e Tendências. Brasil Pack Trends 2005 - Embalagem, Distribuição e Consumo, edição 2000, p.1-17, 2000.

6 SARANTÓPOULOS, C.I.G.L. Principais Tendências de Embalagem para Alimentos - O Cenário do Novo Milênio. Brasil Pack Trends 2005 Embalagem, Distribuição e Consumo, edição 2000, p.107-126, 2000.

7 RICE, J. Irradiated Packaged Foods Processing, n.6, p.52-55, 1989.

8 MOURA E.A.B.; ORTIZ A.V.; WIEBECK, H.; ANDRADE E SILVA , L.G.; MORI, M.N. Efeito da Radiação Gama sobre as Propriedades Mecânicas de Materiais de Embalagens Plásticas Flexíveis. In: $15^{\circ}$ CBECIMAT - CONGRESSO BRASILEIRO DE ENGENHARIA E CIÊNCIA DOS MATERIAIS, Novembro 09-13, 2002, Natal - Rio Grande do Norte - Brasil. Proceedings... Rio Grande do Norte: SBPMat, 2002. 1 CD-ROM.

9 WORLD HEALTH ORGANIZATION; INTERNATIONAL ATOMIC ENERGY AGENCY; FOOD AND AGRICULTURE ORGANIZATION OF THE UNITED NATIONS. High-Dose Irradiation: Wholesomeness of Food Irradiation With Doses Above 10 kGy. Report of a Joint FAO/IAEA/WHO Expert Committee. Geneva, World Health Organization, 1999 ( WHO Technical Report Series, No 890). 
10 ROSS, R.T., ENGELOHN, D. Food Irradiation in the United States: Irradiation as a Phytosanitary Treatment for Fresh Fruits and Vegetables and for the Control of Microorganisms in Meat and Poultry. Rad. Phys. Chem. v.57, p.211-214, 2000.

11 OLSON, D.G. Irradiation of Food Scientific Status Summary. Food Technology, v.52, n.1, p.56-62, 1998.

12 MESSICK, J. Packaging Materials Issues in Irradiation Processing of Foods. Disponível em: < http://www.ebeamservices.com/ebeam spe poly.htm >. Acesso em 12 out. 2005.

13 FENGMEI, L.; YING, W.; XIAOGUANG, L.; BAOYU, Y. Evaluation of Plastic Packaging Materials Used in Radiation Sterilized Medical Products and Food. Rad. Phys. Chem., v.57, n.3-6, p.435-439, 2000.

14 BUCHALLA, R.; SCHÜTTLER, C.; BÖGL, K.W. Effects of Ionizing Radiation on Plastic Food Packaging Materials: A Review, Part 1, Chemical and Physical Changes. J. Food Prot. v.56, n.11, p.991-997, 1993a.

15 CLEGG, D.W.; COLLYER, A.A. Irradiation effects on polymers. New York, N.Y.: Elsevier Science, 1991.

16 SCOTT, G. Mechanisms of polymer degradation and stabilization. New York, N.Y.: Elsevier Applied Science, 1990.

17 GOULAS, A.E.; RIGHANAKOS, K. A.; KONTOMINAS, M.G. Effect of Ionizing Radiation on Physicochemical and Mechanical Properties of Commercial Multilayer Coextruded Flexible Plastics Packaging Materials. Rad. Phys. Chem., v.68, p.865-872, 2003.

18 RESOLUÇÃO - RDC no 21, de 26 de janeiro de 2001 Diário Oficial de 29/1/2001.

19 SARANTÓPOULOS, C.I.G.L.; OLIVEIRA, L.M.; ANJOS, V.D.A.; ALVES, R.M.V.; ARDITO, E.F.G. Embalagem para Produtos Cárneos. 1a edição. Campinas: CETEA/ITAL, 1991.

20 SARANTÓPOULOS, C.I.G.L.; OLIVEIRA, L.M. Sistemas de embalagens plásticas para preservação de carne bovina e derivados. Ciência e Tecnologia da Carne Bovina. Campinas: CTC/ITAL, p.58-70, 1994. 
21 SARANTÓPOULOS, C.I.G.L., OLIVEIRA, L.M., ANJOS, V.D.A., ALVES, R.M.V., ARDITO, E.F.G. Embalagens Plásticas Flexíveis: Principais Polímeros e Avaliação de Propriedades. 1a edição. Campinas: CETEA/ITAL, 2002.

22 CANEVAROLO JUNIOR, S.V. Ciência dos Polímeros. $1^{\text {a }}$ edição, São Paulo, SP.: Artliber Editora, 2002.

23 CALLISTER JUNIOR, W. D. Ciência e Engenharia de Materiais: Uma Introdução. $5^{a}$ edição. Rio de Janeiro, RJ. :Livros Técnicos e Científicos, 2002.

24 HARADA, J. Polímeros para embalagens. Apostila elaborada para o curso: Polímeros para Embalagens, promovido pela Associação Brasileira de Polímeros - ABPol, Junho, 2001, São Carlos, São Paulo.

25 RABELLO, M. Aditivação de Polímeros, $1^{\text {a }}$ edição, São Paulo, SP.: Artliber Editora, 2000.

26 ORTIZ, A.V. Avaliação de propriedades mecânicas e de barreira a gases em embalagem plástica multicamada composta de polietileno de baixa densidade e poliamida tratada com radiação ionizante. 2005. Dissertação (Mestrado) - Escola Politécnica da Universidade de São Paulo, São Paulo.

27 MIRANDA, L.F. Estudo de parâmetros de processo para a síntese de membranas hidrofílicas a base de poli(n-vinil-2-pirrolidona). 1999. Tese (Doutorado) - Instituto de Pesquisas Energéticas e Nucleares, São Paulo.

28 BROADY, A.L.; MARSH, K.S. The Wiley Encyclopedia of Packaging Technology, 2a edição. EUA: John Wiley and Sons, Inc., 1997.

29 WIEBECK, H.; HARADA, J. Plásticos de Engenharia, $1^{\text {a }}$ edição, São Paulo, SP.: Artliber Editora, 2005.

30 DEPARTMENT OF MATERIALS SCIENCE AND ENGINEERING CORNELL UNIVERSITY; UHMWPE - Sterilization - Radiation Chemistry - New Materials. Disponível em: < http://www.mse.cornell.edu/courses/engri119/>. Acesso em 17 out. 2005.

31 MANO, E.B.; MENDES, L.C. Introdução a Polímeros, $2^{\mathrm{a}}$ edição, São Paulo, SP.: Edgard Blucher, 1999. 
32 Roman, A. Polietileno PEBD Processo de Transformação. edição, São Paulo, SP.: Ed Érica, 1997.

33 WIKIPEDIA, THE FREE ENCYCLOPEDIA. Apresenta um histórico, a classificação e as propriedades de diversos polímeros. Disponível em: < http://en.wikipedia.org/wiki/Polymer>. Acesso em 17 out. 2005.

34 HOTCHKISS, J.H, Food-packaging interactions influencing quality and safety. Food Addit. Contam. v.14, p.601-607, 1997.

35 BASF. Apresenta informações sobre poliamidas. Disponível em: < http://iwww.plasticsportal.com/products/ultramid.html > Acesso em 17 out. 2005.

36 VAN WILLIGE, R.W.G. Effects of flavour absorption on foods and their packaging materials, PhD thesis, Wageningen University, The Netherlands, 2002.

37 LENNERSTEN, M.; LINGNERT, H. Influence of Wavelength and Packaging Material on Lipid Oxidation and Colour Changes in Low-fat Mayonnaise. Lebensmittel-Wissenshaft und-Technologie, v.33, p.253-260, 2000.

38 DELASSUS, P.T.; TOU, J.C.; BABINEE, M.A., RULF, D.C., KAARP, B.K.; HOWELL, B.A.; Transport of apple aromas in polymer films. Food and Packaging Interactions, Ed by Hotchkiss JH. ACS Symposium Series 365, American Chemical Society, Washington, DC, p.11-27, 1988.

39 HALEK, W.G. Relashionship between polymer structure and performance in food packaging applications. ACS Symposium Series 365, American Chemical Society, Washington, DC, p.196-202, 1988.

40 SPINKS, J.W.T. \& WOODS, R. J. An Introduction to Radiation Chemistry. New York: John Wiley e Sons Inc. 1990.

41 EISBERG, R.E.; RESNICK, R. Física Qüântica. Rio de Janeiro: Ed.Campus, 1998.

42 TABATA, Y. Fundamentals in radiation chemistry, JETRO - Japan External Trade Organization, p.1-17, 1981.

43 O ' DONNELL, J.H. \& SANGSTER, D. F. Principles of Radiation Chemistry. New York, N.Y. : Arnold E., 1970. 
44 CHAPIRO, A. Radiation induced polymerization. Radiat. Phys. Chem., v.14, p.101-16, 1979.

45 CHAPIRO, A. Radiation-induced reactions. In: Encyclopedia of Polymer Science and Technology, John Wiley. New York, v.11, p.702-760, 1969.

46 CHARLESBY, A. Atomic Radiation and Polymers. Oxford: Pergamon, 1960.

47 PLATZER, N.A.J. Irradiation of Polymers. Washington, Wash.: American Chemical Society, 1967.

48 INTERNATIONAL ATOMIC ENERGY AGENCY Radiation Safety of Gamma and Electron Irradiation Facilities. 1992. (IAEA Safety Series n. 107, Vienna - Austria, 1992).

49 YAMASAKI, M.C.R. A cura de tintas, vernizes e revestimentos por ultravioleta e feixe de elétrons - conceitos básicos. Apostila elaborada para o curso: A cura de tintas, vernizes e revestimentos por ultravioleta e feixe de elétrons - conceitos básicos. Associação Técnica Brasileira de Cura por Radiação - ATBCR e IPEN-CNEN/SP, São Paulo, outubro, 1997.

50 MEHNERT, R. Electron Beam in Research and Technology. Nuclear Instruments and Methods in Physics Research - Section B, v.105, p.348-358, 1995.

51 IBA - Apresenta informações sobre aceleradores de elétrons: tipos de aceleradores, princípio de funcionamento e aplicações. Disponível em: < http://www.iba-worldwide.com > Acesso em 19 out. 2005

52 MOURA, E.A.B.; ORTIZ, A.V.; WIEBECK, H.; PAULA, A.B.A.; SILVA, A.L.A.; ANDRADE E SILVA, L.G. Effects of Gamma Radiation on Commercial Food Packaging Films - Study of Changes UV/VIS Spectra. Rad. Phys. Chem., v. 71, p. 199-202, 2004.

53 ROJAS DE GANTE, C.; PASCAT, B. Effects of $\beta$-Ionizing Radiation on the Properties of Flexible Packaging Materials. Packag. Technol. Sci., v.3, n.2, p.97-102, 1990.

54 RIGHANAKOS, K.A.; KOLLER, W.D.; EHLERMANN, D.A.E.; BAUER, B.; KONTOMINAS, M.G. Effects of Ionizing Radiation on Properties of Monolayer and Multilayer Flexible Food Packaging Materials. Rad. Phys. Chem., v.54, p.527-540, 1999.

55 ORTIZ, A.V.; MOURA, E.A.B.; COELHO, A.C.V. Effects of e-beam Radiation on Commercial Multilayer PA/PE Packaging Film. In: PPS 2004 -Americas Regional 
Meeting, Florianópolis (SC), Novembro 7-10, $2004 . \quad$ Proceedings... Florianópolis: PPS, 2004. p.260-265, 2004.

56 BUCHALLA, R.; BOESS, C.; BÖGL, K.W. Characterization of Volatile Radiolysis Products in Radiation-Sterilized Plastcs by Thermal Desorption-Gas Chromatography-Mass Spectrometry: Screening of Six Medical Polymers. Rad. Phys. Chem., v.56, p.353-367, 1999.

57 CLOUGH R.L.; GILLEN K.T.; MALONE G.M.; WALLACE J.S. Color Formation in Irradiated Polymers. Rad. Phys. Chem., v.48, n.5, p.583-594, 1996.

58 SEN, M.; BASFAR, A.A. The Effect of UV Light on the Thermooxidative Stability of Linear Low Density Polyethylene Films Crosslinked by Ionizing Radiation. Rad. Phys. Chem., v.52, p.247-250, 1998.

59 ICGFI - Apresenta informações sobre irradição de alimentos. Disponível em: < http://www.iaea.org/icgfi/programmes.htm > Acesso em 10 jan. 2006

60 AMERICAN SOCIETY FOR TESTING AND MATERIALS. - ASTM. Standard Test Methods for Tensile Properties of Thin Plastic Sheeting. D 882-91. ASTM, 1996.

61 AMERICAN SOCIETY FOR TESTING AND MATERIALS. - ASTM. Standard Test Method for Slow Rate Penetration Resistance of Flexible Barrier Films and Laminates. F 1306-90. ASTM, 1994.

62 AMERICAN SOCIETY FOR TESTING AND MATERIALS. - ASTM. Standard Test Methods for Transparency of Plastic Sheeting. D 1746-92. ASTM, 1996.

63 AMERICAN SOCIETY FOR TESTING AND MATERIALS. - ASTM. Standard Test Methods for Water Vapor Transmission Rate Through Plastic Film and Sheeting. F 372-99. ASTM, 1999.

64 AMERICAN SOCIETY FOR TESTING AND MATERIALS. - ASTM, Standard Test Methods for Oxigen Gas Transmission Rate Through Plastic Film and Sheeting Using a Coulometric Sensor. Filadélfia. D 3985 - 81. ASTM, 2002.

65 RESOLUÇÃO No. 105/99 ANVS/MS. de 18/05/99. Diário Oficial da União, 20 de Maio de 1999. 
66 DANTAS, S.T.; KIYATA, P.H. Relatório de Ensaio de Embalagens Plásticas Flexíveis da Unipac - Indústria de Embalagem Ltda. Centro de Pesquisa e Desenvolvimento de Embalagens, CETEA/ITAL - CENTRO DE TECNOLOGIA DE EMBALAGEM DO INSTITUTO DE TECNOLOGIA DE ALIMENTOS, Campinas, 14 de Fevereiro de 2005, Campinas-SP.

$67 \mathrm{CLOUGH}, \mathrm{R}$. Radiation - resistant polymers. In: Encyclopedia of Polymer Science and Engineering. New York, N.Y.: Wiley-Interscience, 2 ed., v.13, p.667-708, 1988.

68 FARIA, J.; ATENCIA, E. Desempenho dos Polímeros é Aprovado para a Irradiação. Plástico Moderno, Novembro, p.20-22, 1992.

69 DEMERTZIS, P.G.; FRANZ, R.; WELLE, F. The Effects of Gama-Irradiation on Compositional Changes in Plastic Packaging Films. Packaging Technology and Science, v.12, p.119-130, 1999.

70 MOURA, E.A.B.; ORTIZ, A.V.; GOUVÊA, D.; CASTRO, R.H.R.; ROSSINI, E.L.; SILVA, A.L.A.; GOUVÊA, P.H.D.; WIEBECK, H.; KAWANO, Y.; ANDRADE E SILVA, L.G. Estudo por FIIR de Filme de Polietileno de Baixa Densidade Submetido à Radiação Gama na Presença de Oxigênio. In: 70 CONGRESSO BRASILEIRO DE POLÍMEROS - Belo Horizonte - MG, Novembro, 09-13, 2003. Proceedings... Belo Horizonte: ABPol, 2003. 1 CD ROM

71 GOULAS, A.E.; RIGHANAKOS, K.A.; KONTOMINAS, M.G. Effect of Ionizing Radiation on Physicochemicaland Mechanical Properties of Commercial Monolayer and Multilayer Semirigid Plastics Packaging Materials. Rad. Phys. Chem., v.69 p.411-417, 2004.

72 BUCHALLA, R. Radiolysis products in gamma-irradiated plastics by thermal desosption - gas chromatography - mass spectrometry. 2000. PhD thesis - Lebensmitteltechnologie und Biotechnologie der Thechnischen Universittät Berlin, Berlin, Germany.

73 ALLEN, D.W.; LEATHARD, D.A.; SMITH, C. The Unespected Degradation on an Internal Standard the H.P.L.C. Determination on Anti-Oxidantes in GammaIrradated Food Contact Polyolefins: a Possible Basis for a Chemial Test for an Irradated Plastic. Chemistry and Industry, v.16, jan., p.38-39, 1989.

74 BUCHALLA, R.; SCHÜTTLER, C.; BÖGL, K. W., Effects of Ionizing Radiation on Plastic Food Packaging Materials: A Review, Part 2, Global Migration, Sensory Changes, and the Fate of Additives.. J. Food Prot.. v.56, n.11, p.998-1014, 1993b. 
75 VIEIRA, T.M.; REGITANO-D'ARCE, M.A.B. Stability of Oil Heated by Microwave: UV-Spectrophotometric Evaluation. Ciência e Tecnologia de Alimentos, v.18, n.4, Campinas, 1998.

76 LENNERSTEN, M.; LINGNERT, $\mathrm{H}$. Influence of Wavelength and Packaging Material on Lipid Oxidation and Colour Changes in Low-fat Mayonnaise. Lebensmittel-Wissenschaft und-Technologie, v.33, p.253-260, 2000.

77 MOYSSIADI, T.; BADEKA, A.; KONDYLI, E.; VAKIRTZI,T.; SAVVAIDIS, I.; KONTOMINAS ,M.G. Effect of light transmittance and oxygen permeability of various packaging materials on keeping quality of low fat pasteurized milk:chemical and sensorial aspects. International Dairy Journal, v.14 p.429-436, 2004. 